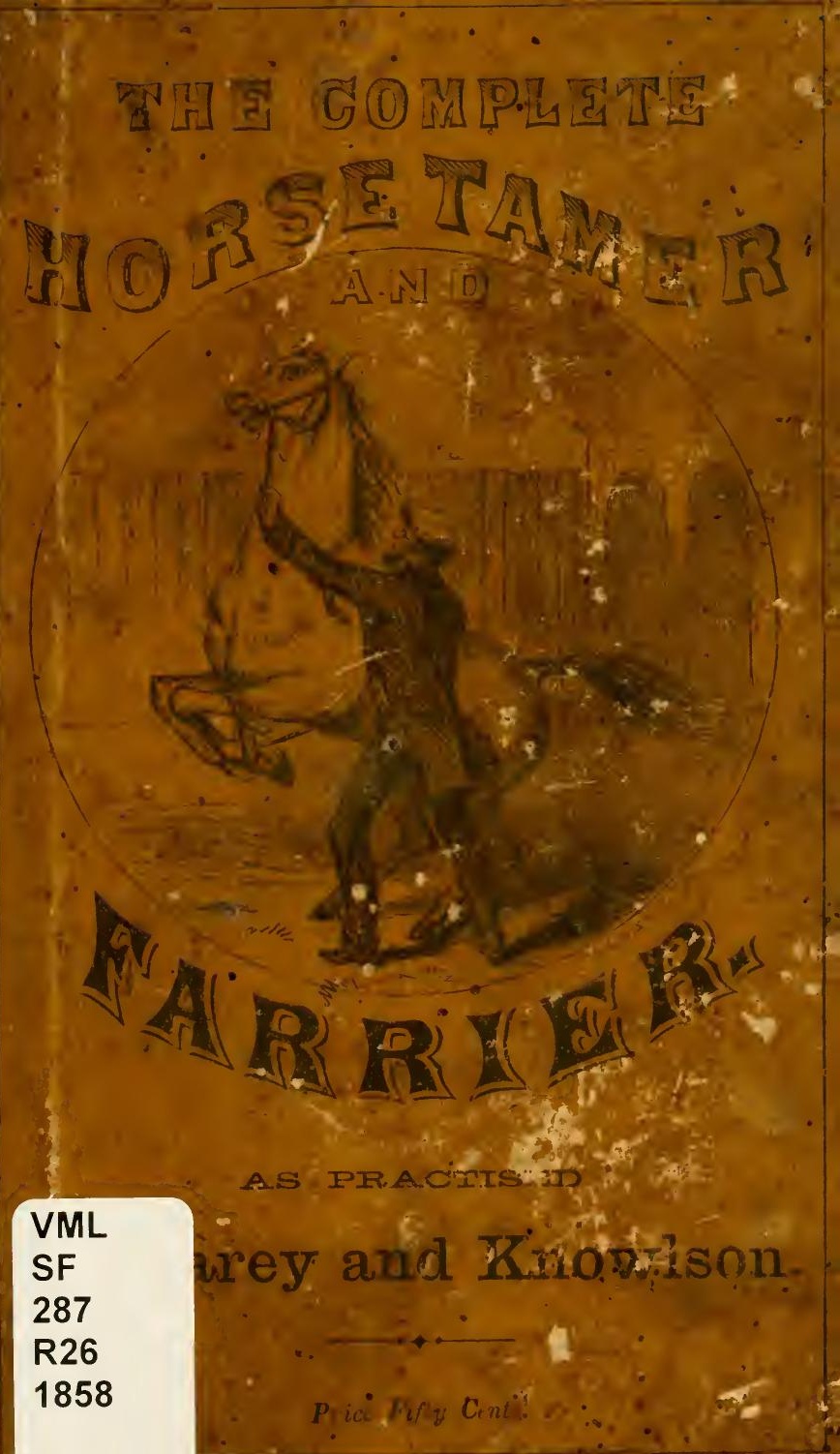




\section{The NCSU Libraries}

\section{North Carolina State University}

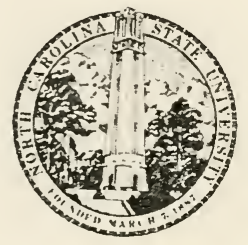

\section{This book was presented by}

\section{Charlotte Litwack}

Innexed.

ny Books in this
er by mail or ex-
ok you uanl you
Uhe same day z
E.
, Life in Nezo

Adventures of a spirited romance lis great city, in look of near 100 .........25 cts.

vents which FrWTON M. CURrrative of a mysder into all soits ney maker, to the pssible.

........2.25 cts.

history of life ho have no homes Bowery boys, etc. ........25 cts.

This excithe metropolis. It ithe victim of vice, races 117 pages of closely printed matter. Ṕrice..............................25 cts.

The Orphan Seamstress. A Narrative of Innocence, Guilt, Mystery and Crime. By the author of "Caroline Tracy." This narrative of events in New York is especially interesting, as it alludes to incidents which every newspaper reader must remember. Price............25 cts.

Clarence Bolton. A New York story, with city life in all its phases. This is one of those fascinating tales of city life that gives ar insight into every class of society. Price.......................25 cts.

Grace Weldon; or, The Pretly Millincr. This is a story about the Sewring Girls of Boston. Full of fun and adventure. Any person who desires to read a lively story should not fail to gat this work.

Price ...................................................25 cts.

Chips from Uncle Sam's Jack-knife. Illustrated with over 100 Comical Engravings, and comprising a collection of over 500 Laughable Dtories, Funuy Adventures, Comic Poetry, Queer Conundrums, Terrific Puns, Witty Sarings, Sublime Jokes and Sentimental Sentences. The whole being a most perfect portfolio for those who love to laugh.

Large octavo. .25 cts 
Barton's Comic Recitations and Fiumorous Dialogues. Containing a variety of Comic Recitations in Prose and Poetry, Amusing Dialogues, Burlesque Scenes, Eccentric Orations and Stump Speeclies, Humorous Interludes and Laughable Farces, designed for school Commencements and Amateur Theatricals. Edited by JERome Barton.

180 pages, paper. Price.....................................

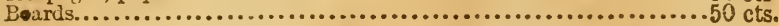

Brudder Bones' Book of Stump Speeches and Burlesque Orations. Also containing Humorous Lectures, Ethiopian Dialogues, Plan. tation scenes, Negro Farces and Burlesques, Laughable Interludes and Comic Recitations, interspersed with Dutch, Irish, French and Yankee Stories. Edited by Joнn F. Sсотт. Paper covers, Price.................... 30 cts. Bound in boards, illuminatẹd................................. 50 cts.

Wilson's Book of Recitations and Dialogues. With Instructions in Elocution and Declamation. Containing a choice selection of Poetical and Prose Recitations and Uriginal Colloquies. Designed as a Reading Book for Classes, and as an Assistant to T'eachers and Students in preparing Exhibitions. By FLOXD B. WILsos, Professor of Elocution. 186 pages, 16 mo., paper covers. Price.............................. Bound in boards, eloth back ................................. 50 cts.

Spencer's Book of Comic Speeches and Humorous Recitions. A collection of Comic Speeches and Dialogues, Humorous Prose and Poetical Recitations, Laughable Dramatic Scenes and Burlesques, and Eccentric Characteristic Soliloquies and Stories. Suitable for School Exhibitions and Evening Entertainments. Edited by Albert J. Spencer.

192 pages, $18 \mathrm{mo}$., paper covers. Price.............................. Bound in boards, cloth back.............................. 50 cts. Frost's Dialogues for Young Folks. A collection of Orig-
inal Mroral and Humorous Dialogues. Adapted to the use of School and Church Exhibitions, Family Gatherings, and Juvenile Celebrations. B: S. A. Frost, author of "The Parlor Stage." Paper covers. Price...30 cts. Bound in boards, cioth back, side in colors...................... 50 cts.

Amateur Theatricals, and Fairy-Tale Dramas. A collection of Original Plays, expressly designed for Drawing-room pertormance. By S. A. Frost. This work is designed to meet a want, which has been long felt, of short and amusing picces suitable to the limited stage of the private parlor. 16 mo., 188 pages, paper covers. Price...................... 30 cts. Boards, cloth back.............................................

Parlor Theatricals; or, Winter Evenings' Entertrinment. A collection of Dramatic Amusements and Comic Plays. Illustrated with cuts and diagrams. Paper covers. Price.........................

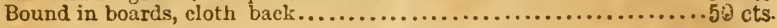

The Parlor Stage. A collection of Drawing-Roon Proverbs, Charades and Tableaux Virants. By IIiss S. A. Frost. These plays are intended solely for performance by a small party of friends, in rrivie parlors, and require but little trouble or expense to render them effertiv: 368 pages, small octaro, cloth, gilt side and back. Pricc............ \$1 50

Frost's Book of Tableaux. Containing 160 Tibleaux Vivants, with directions for arranging the stage, costuming the characters, and forming appropriate groups. By S. ANNif. Fnost, author of "The Parlor Stage, "Amateur Theatricals," etc. To those who desirc to get up an evening's entertain

Paper covers. Price...................................... 30 cts

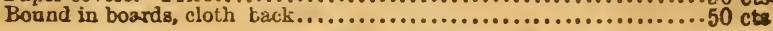




\section{Popular Books sent Free of Postage at the Prices annezed.}

The Modern Pocket Hoyle. Containing all the Games of Skill and Chance, as played in this country at the present time; being "An authority on all disputed points." By."Trumps." This valuable manual is all original, or thoroughly revised from the best and latest authorities, and includes the laws and complete directions for playing one hundred and eleven difticrent Games-comprising Card Games, Chess, Checkers, Dominoes, Backgammon, Dice, Billiards, and all the Ficld Gatmes.

16 mo., 388 prges, papcr covers. Price.......................... 50 cts.

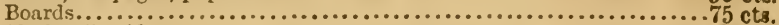

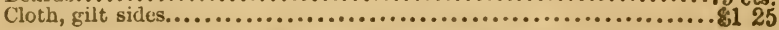

Rarey and Knowlson's Complete Fiorse-Tamer and Farrier. $\Delta$ new and improved edition, containing Mrr. Rarey's whole Secret of Subduing and lireaking Vicious Horses, together with his Improved Plan of Manaring Young Colts, and breaking them to the Saddle, the Harness and the Sulkey. Also, Thu Couplete Fanrier; or, Horse Doclor; a Guide tor the Treatment of Horses 11 all Diseases to which that noble animal is liable, being the result of fifty years' extensive practice of the author, Jows C. KNowlsow. Illustrated with descriptive Engravings.

Bound in boards, cloth back. Price........................... 50 cts.

"Trumps'" American Hoyle; or, Gentleman's Iland-Book of" Games. Containing clear and complete descriptions of all the Games played in the United States, with the American Rules for playing them. 'The wholo contains 525 pages, is printed on tine white paper, bound in cloth, with beveled edges, and is profusely illustrated with engravings explaining the ditterent Giames.

Price............................................... \$2 00

Hilf calt, marble edges ................................ 400

Spayth's Draughts cr Checkers for Deginners. Being a comprehensive $G$ uide for those who desire to learn the Game. This treatise was written ly HENRY Sraxth, the celebrated player, and is by far the most complete and instructive elementary work on Draughts ever published.

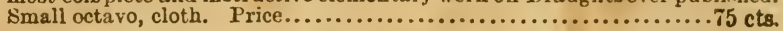

The Game of Draughts or Checkers, Simplified and Explained. With Practical Diagrams and Illustrations, together with a Checker-board, numbered and printed in sed. Containing the eighteen standard games, with over 200 of the hest variations. By D. ScATTERGOOD. Bound in cloth, with flexible cover. Price....................... 50 cts.

\section{Marache's Manual of Chess. Containing Preliminary} Games for Beginner, fifty Openings of Games, grving all the latest discoveries of modern masters, with best Games and Copious Notes, Endings of Games, Problems, Diagrams, etc. By N. Marache.

Cloth, gilt sile. Price......................................

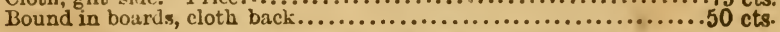

'Duncan's Masonic Ritual and Monitor; or, Guide to the Three Symbolic Degrees of the Ancicnt York Rite. And to the Degrees of Mark Master. Past Master, Most Excellent Master, and the Royal Arch. Containing all the Iectures, etc. By Malcoly C. Duncax.

Bound in cloth. Price................................. $\$ 2$

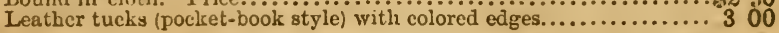

Richardson's Monitor of Freemasonry. A Complete Guide to the various Ceremonies and Routine in Freemasons' Lodges, Chapters, Encampments, Hierarchies, etc.

Paper covers. Price......................................7 g cts,

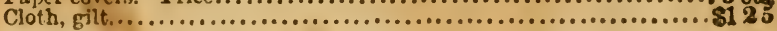




\section{T A II N G \\ $\dot{\mathrm{o}} \mathbf{B}$}

\section{BREAKING THE HORSE.}

BY A NEW AND IMPIOVED METHOD,

AS PRACTICED WITI GREAT SUCCESS IN THE UNITED STATES, AND IN ALL THE COUNTRIES OF EUROPE.

\section{BY J. S. RAREY.}

CONTAINING RULES FOR SELECTING A GOOD HORSE, FOR FEEDING HORSES, \&c.

ALso,

\section{THE COMPLETE}

\section{FARRIER, OR HORSE DOCTOR;}

A GUIDE FOR THE

TREATMENT OF HORSES IN ALL DISEASES TO WHICH THAT NOBLE ANIMAL IS LIABLE,

Being the Result of Fifty Years Extensive Practice of the Aathor.

\section{BY JOHN C. INNOWISON,}

DCHING HIS LIFE, AN ENGLISII FARRIER OP HIGH POPULARITY.

CONTAINING THE LATEST DISCOVERIES IN THE CURE 0 SPAVIN.

NEW YORK :

DICK \& FITZGERALD, PUELISHERS; 18 ANN STREM.

NORTH CAROLINA STATE UNIVERSITY LIBRARIES

ORTH CAROLINA STATEUNIVESITY LIBRAR

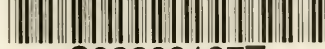

S02209187T 


\section{INDEX TO CONTENTS}

Balky Horses, how to manage .........................45

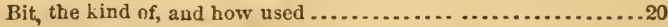

Blinds, or Blinkers ................................. 58

Breaking the Horse to Harness ..........................27

Choking a means of subduing the Horse................... 50

Choking, (illustrated,) process of ..................... 53

Directions how to lay the Horse down, \&c..................34

Feeding the Horse, rules for...........................60

Follow you, how to learn a Horse to...................... 55

General Rules and Remarks on Choking....................5

Halter for the Colt, the kind to be used, \&c................ 9

Haltering the Colt, how to proceed after...................10

Harness, breaking the Horse to.......................27

Hitching the Horse to a Sulky ...........................28

Knowledge and Capacity of the Horse.................... 5

Laying Down the Horse, how to do it...................... 33

Laying Down the Horse, (illustrations)........31, 35, 39, 41 and 43

Leading the Colt with a Broke Horse.......................14

Leading the Colt into a Stable............................ 15

Minute Directions to Lay the Horse Down..................34

Mounting the Colt, how to do it .........................23

Pasture, how to get the Colt from........................ 7

Powell's Mranagement of Wild Horses......................17

Principles of the New Method of Horse-Taming............ 6

Purchasing a Horse, rules for...........................61

Putting a Halter on the Colt........................... 9

Riding a Colt, how to do it.............................25

Saddling the Colt......................................

Scaring, how to prevent a Horse from .....................57

Stabling the Colt, how to do it....................... 15

Stand without Holding, how to make the Horse...............56

Stubborn Colt, bow to manage one......................12

Taming a Horse with Vicious Habits...................... 99

Timid:ty of the Horse............................... 5

Treatment after the Horse is down......................42

Vicious Habits in a Horse, treatment of....................29

Wild Horses, Powell's management of .................. 17 


\section{INTRODUCTORY.}

Since issuing our former editions of Mr. Rarey'b book on Horse Taming, some new facts have been published by him, which are embodied in these pages, and make the work still more complete. A careful perusal of the instructions here given, will show how any cool and determined person may break or tame a colt in a manner that will make him docile, stand at the word of command, and obey the voice with as much certainty as ordinarily trained horses will answer the reins. In contrast with the usual mode of training by harsh words, a sharp whip, and cruel worrying, Mr. Rarey demonstrates how easily, quietly and safely horses may be tamed by kindness. For training _ colts, breaking horses into harness, curing vicious horses, such as kickers and baulkers, this system is invaluable. Indeed, it will give to every courageous, calm-tempered horseman not only the power to conquer any horse, however refractory, but to make the animal affectionate in disposition and ready at all times to be mounted and put in harness, without trouble or waste of time.

One great value of Mr. Rarey's system consists in the fact that it may be taught to, and successfully practiced by, persons of little strength-even by boys of fourteen-except where the horse is extremely vicious and powerful. It requires patience, and the habit of dealing with horses, as well as cool. ness; but the real work is rather a matter of skill 
than muscle. Not only have boys of eighty pounds weight become successful horse-tamers in England, but even English ladies have perfectly subdued and reduced to calmness fiery blood-horses. Therefore, in dealing with Mr. Rarey's plan we are not wasting our time about a trick for conquering incurably savage horses, but are elucidating the principles of a universally applicable system for taming and training horses for man's use, with a perfection of docility rarely found except in aged pet horses, and with a rapidity heretofore quite unknown.

John S. Rarey is about thirty years of age, of middle height, and well-proportioned figure, wiry and active rather than muscular-his complexion is almost effeminately fair, with more color than is usually found in those of his countrymen who live in cities. He was a citizen of Groveport, Ohio, when he began his successful mode of horse-taming. His walk is remarkably light and springy, yet regular, as he turns round his horse; something between the set-up of a soldier and the light step of a sportsman. Altogether his appearance and manners are eminently gentlemanly. Although a self-educated and not a book-educated man, his conversation, when he cares to talk, (for he is rather reserved,) always displays a good deal of thoughtful originality, relieved by flashes of playful humor.

Mr. Rarey's system of horse-taming will infallibly supersede all others for both civil and military purposes, and his name, will take rank among the great social reformers of the nineteenth century. 


\section{HORSE TAMING, \&c}

THE Horse is so constituted by nature that he will not offer resistance to any demand made of him which he fully comprehends. He has no consciousness of his strength beyond his own experience, and can be handled by man without force, after a little study of his habits and disposition. Being deficient in reasoning powers, he has no knowledge of right or wrong, of free will and independent government. and knows not of any imposition practiced upon him, however unreasonable it may be. Consequently, he cannot easily decide what he should or should not do. But being naturally of willing and gentle disposition, it remains for man to instruct him in a manner suited to his nature.

'The horse is a timid animal; but easily becomes familiar with objects and sounds that are at first disagreeable or frightful. We must therefore accustom him to such as he will be apt to meet with in his daily service. To do this effectually, he should be allowed to examine closely and leisurely such objects as would inspire terror, and to smell them and touch them. A $\log$ or stump by the road-side may be, in the imagination of the horse, som great beast about to pounce upon him; but after you take him up to it, and let lim stand by it a little while, and touch it with his nose, and go through his process of examination, he will not care anything more about it. And the same principle and process will have the 
same effect with any other object, however frightful in appearance, in which there is no harm.

I thus establish three principles on which my system of taming the horse is founded, viz. :

First. That any horse may be taught to do anything that a horse can do if taught in a systematic and proper manner.

Second. That a horse is not conscious of his own strength until he has resisted and conquered a man, and even in cases where he has temporarily triumphed he may yet be subdued; - that by taking advantage of man's reasoning powers a horse can be handled in such a manner that he shall not find out his strength.

Third. That by enabling a horse to examine every object with which we desire to make him familiar, with the organs naturally used for that purpose, viz., seeing, smelling and feeling, you may place or display the object around, over, and on him, provided that it does not actually hurt him or make him feel disagreeable.

With this introduction to first principles, I will endeavor to teach you how to put them into practice, and whatever instructions may follow, you can rely on as having been proven practical by my own experiments. Knowing from experience just what obstacles I have met with in handling bad horses, I shall try and anticipate them for you, and assist you in surmounting them, by commencing with the first steps to be taken with the colt, and accompanying you through the whole task of breaking. 
HOW TO GET THE COLT FROM PASTURE.

Go to the pasture and walk around the whole herd quietly, and at such a distance as not to cause them to scare and run. Then approach them very slowly, and if they stick up their heads and seem to be frightened, hold on till they become quiet, so as not to make them run before you are close enough to drive them in the direction you want them to go. And when you begin to drive, do not flourish your arms or halloo, but gently follow them off, leaving the direction free for them that you wish them to take. Thus taking the advantage of their ignorance, you will be able to get them in the pound as easily as the hunter drives the quails into his net. For if they have always run in the pasture uncared for, (as many horses do in prairie countries and on large plantations,) there is no reason why they should not be as wild as the sportsman's birds, and require the same gentle treatment, if you want to get them without trouble; for the horse, in his natural state, is as wild as any of the undomesticated animals, though more easily tamed than the most of them.

\section{HOW TO STABLE A COLT.}

The next step will be to get the horse into a stable or shed. This should be done as quietly as possible, so as not to excite any suspicion in the horse of any danger befalling him. The best way to do this, is to lead a broken horse into the stable first and hitch 
him, then quietly walk around the colt and let him go in of his own accord. Be extremely deliberate and slow in your movements, for one wrong move may frighten your horse, and make him think it necessary to escape at all hazards for the safety of his life-and thus make two hours' work of a ten minutes' job; and this would be all your own fault, and entirely unnecessary-for he will not run unless you run after him, nor will he try to break away unless you attempt to force him into measures. If he does not see the way at once, and is a little fretful about going in, do not undertake to drive him, Dut give him a little less room outside, by gently closing in around him. Do not raise your arms, but let them hang at your side, for you might as well raise a club: the horse has never studied anatomy, and does not know but they will unhinge themselves and fly at him. If he attempts to turn back, walk before him, but do not run; and if he gets past you, encircle him again in the same quiet manner, and he will soon find that you are not going to hurt him; and then you can walk so close around him that lie will go into the stable for more room, and to get farther from you. As soon as he is in, remove the quiet horse and shut the door. This will be his first notion of confinement-not knowing how he got into such a place, nor how to get out of it. That he may take it as quietly as possible, see that the shed is entirely free from dogs, chickens, or anytling that would annoy him. Then give him a few ears of corn, and let him remain alone fifteen or twenty 
minutes, until he has examined his apartment, and has become reconciled to his confinement. And now, while your horse is eating those few ears of corn, see that your halter is ready and all right, and reflect upon the best mode of operations; for, in horse-breaking, it is highly important that you should be governed by some system.

THE KIND OF HALTER, AND HOW TO PUT IT ON.

Never use a rope halter. The cords of the rope are hard, and appear to aggravate and excite distrust rather than confidence; but by all means procure a leather halter made of bridle leather, so it will feel soft and pliable to the touch, and to fit tolerably tight on the head, so as not to feel uncomfortable. Before putting a halter upon the colt, he must be rendered familiar with it by caressing him and permitting him to examine the article with his nose. Then place a portion of it over his head, occasionally giving it a slight pull, and in a few minutes he will be accustomed to these liberties, and then the halter may be fastened on properly. To teach him to lead is another difficulty. Stand a little on one side, rub his nose and forehead, take hold of the strap and pull gently, and at the same time touch him very lightly with the end of a long whip across his hind legs. 'This will make him start and advance a few steps. Repeat the operation several times, and he will soon learn to follow you by simply pulling the halter. The mouth of the colt should be frequently bandled, after which introduce a plain snafle bo- 
tween his teeth and hold it there with one hand and caress him with the other. After a time he will allow the bridle to be placed upon him. The saddle can now be brought in and rubbed against his nose, lis neck and his legs; next hang the stirup strap across his back, and gradually insinuate the saddle into its place. The girth should not be fastened until he becomes thoroughly acquainted with the saddle. The first time the girth is buckled it should be done so loosely as not to attract his attention; subsequently it can be tightened without inspiring him with fear, which if fastened immediately it would nost certainly do. In this manner the wildest colt can be effectually subjugated by such imperceptible degrees that he gives tacit obedience before he is aware of his altered condition.

\section{HOW TO PROCEED AFTER HALTERING.}

The first time you halter a colt you should stand on the left side, pretty well back to his shoulder, only taking hold of that part of the halter that goes around his neck, then with your two hands about his neck, you can hold his head to you, and raise the halter on it without making him dodge, by putting your hands about his nose. You should have a long rope. or strap ready, and as soon as you have tho halter on, attach this to it, so that you can let him walk the length of the stable without letting go the strap, or without naking lim pull on the halter; for if you only let him feel the weight of your hand on the halter, and give him more rope when he runs 
from you, he will never rear, pull or throw himself, yet you will be holding him all the time, and doing more towards gentling him than if you had the power to snub him right up, and hold him to one spot; because lie knows nothing about his strength, and if you don't do anything to make him pull, he will never know what he can do in that way. In a few minutes you can begin to control him with the halter, then shorten the distance between yourself and the horse by taking up the strap in your hand. As soon as he will allow you to hold him by a tolerably short strap, and to step up to him without flying back, you can begin to give him some idea about leading. But to do this, do not go before and attempt to pull him after you, but commence by pulling him very quietly to one side. He has nothing to brace either side of lis neck, and will soon yield to a steady, gradual pull of the halter; and as soon as you have pulled him a step or two to one side, step to him and caress him, and then pull him again, repeating this operation until you can pull him in every direction, and walk about the stable with him; which you can do in a few minutes, for he will soon think when you have made him step to the right or left a few times, that he is compelled to follow the pull of the halter, not knowing that he has the power to resist your pulling; besides, you have handled lim so gently that he is not afraid of you, but rather likes you. After you have given him a few lessons of this kind, at proper intervals, he will be so tame that if you turn him out to pas- 
ture he will come up to you to be caressed every opportunity he gets.

While training him in the stable, you should lead him about some time before you take lim out: opening the door, so that he can see out, leading him up to it and back again, and then past it. See that there is nothing on the outside to make him jump when you take him out, and as you go out with him, try to make him go very slowly, catching hold of the halter close to the jaw with your left hand, while the right is resting on the top of his neck, holding to his mane. Do not allow any one to be present or in sight, during your operations, either in or outside the stable. If you are entirely alone, and manage your colt rightly, you will soon be able to lead and hold him as easily as you could a horse already broken.

\section{HOW TO PROCEED IF THE COLT IS STUBBORN.}

If the animal you are operating upon seems to be a stubborn or mulish disposition rather than wild; if he lay back his ears as you approach him, or turns his heel to kick you, he has not that regard or fear of man that he should have, to enable you to handle him quickly and easily; and it might do well'to give him a few sharp cuts with the whip, about the legs, pretty close to the body. It will crack keen as it plies about the legs, and the crack of the whip will affect him as much as the stroke; besides, one sharp cut about the legs will affect him more than two or three over the back, the skin on 
the inner part of the legs or about his flanks being thinner, and more tender than on his back. But do not whip him much-just enough to scare him; it is not because we want to hurt the horse that we whip him; we only do it to scare that bad disposition out of him. But whatever you do, do quickly, sharply and with a good deal of fire, but always without anger. If you go to scare him at all, you must do it at once. Never go into a pitched battle with your horse, and whip him until he is mad, and will fight you : you had better not touch him at all, for you will establish, instead of fear and regard, feelings of resentment, hatred, and ill will. It will do him no good, but harm, to strike him, unless you can frighten him; but if you can succeed in frightening him, you can whip him without making him mad; for fear and anger never exist together in the horse, and as soon as one is visible, you will find that the other has disappeared. As soon as you have frightened him, so that he will stand up straight and pay some attention to you, approach him again and caress him a good deal more than you whipped him; thus you will excite the two controlling passions of his nature, love and fear; he will love, and fear you too; and, as soon as he learns what you require, will obey quickly.

If the colt is of too mulish a disposition to yield to careful and gentle treatment, as here given, you must resort to the several measures recommended for taming vicious horses, as explained elsewhere in these pages. 
HOW TO LEAD A COLT WITH A BROKE HORSE.

! If you should want to lead your colt by the side of another horse, you must first put the horse into a stable with the colt. You now attach a second. strap to the colt's halter, and lead your horse up alongside of him. Then get on the broke horse and take one strap around his breast under the martingale, (if he has any on,) holding it in your left hand. 'This will prevent the colt from getting back too far; besides, you have more power to hold him, with the strap pulling against the horse's breast. The other strap take up in your right hand to prevent lim from rumning ahead; then turn him about in the stable, and if the door is wide enough, ride out with him in that position; if not, take the broke horse out first, and stand his breast up against the door, then lead the colt to the same spot and take the straps as before directed, one on each side of his neck, and then let some one start the colt out, and as the colt comes out, turn your horse to the left, and you will have them all right. You can manage any kind of a colt in this way, without trouble; for, if he tries to run ahead, or pull back, the two straps will bring the two horses facing each other, so that you can very easily follow up his movements without doing much holding, and as soon as he stops running backward, you are right with him, and all ready to go ahead. If he gets stubborn and does not want to go, you cán remove all his stubbornness by riding your horse against his neck, thus compelling him to turn to the 
right; and as soon as you have turned him about a few times, he will be willing to go along. 'The next thing, after you are through leading him, will be to take him into a stable and hitch him in such a way as not to have him pull on the halter, and as they are often troublesome to get into a stable the first. few times, I will give you some instructions about getting him in.

\section{HOW TO LEAD THE COLT INTO A STABLE.}

You should lead the broken horse into the stable first, and get the colt, if you can, to follow in after him. If he refuses to go, step up to him, taking a little stick or switch in your right hand; then take hold of the halter close to his head with your left hand, at the same time reaching over his back with your right arm so that you can tap him on the opposite side with your switch; bring him up facing the door, tap him slightly with your switch, reaching as far back with it as you can. 'This tapping, by being pretty well back, and on the opposite side, will drive him ahead, and keep him close to you; then by giving him the right direction with your left hand you can walk into the stable with him. I have walked colts into the stable this way in less than a minute, after men had worked at them half an hour, trying to pull them in. If you cannot walk him in at once in this way, turn him about and walk him around a while until you can get him up to the door without pulling at him. Then let him stand a few minutes, keeping his head in the right direction with 
the halter, and he will soon walk in of his own accord. Never attempt to pull the colt into the stable; that world make him think at once that it was a dangerous place, and if he was not afraid of it before he would be then. Besides, we do not want him to know anything about pulling on the halter. If you want to tie up your colt, put him in a tolerably wide stall, which should not be too long, and should be connected by a bar or something of that kind to the partition behind it; so that, after the colt is in he camnot go far enough back to take a straight, backward pull on the halter; then by tying him in the center of the stall, it would be impossible for him to pull on the halter, the partition behind preventing him from going back, and the halter in the center checking him every time he turns to the right or left. In a stall of this kind you can break any horse to stand tied with a light strap, anywhere, without his ever knowing anything about pulling. For if you have broken your horse to lead, and have taught him the use of the halter (which you should always do before you hitch him to anything), you can hitch him in any kind of a stall, and if you give him something to eat to keep him up to his place for a few minutes at first, there is not one colt in fifty that will pull on his halter, or ever attempt to do so.

This is an important feature in breaking the colt, for if he is allowed to pull on the halter at all, and particuiarly if he finds out that he can break the halter, lse will never be safe. 
POWELL'S MANAGEMENT OF WILD HORSES.

Cause your horse or colt to be put in a small? yard, stable, or room. If in a stable or room, it ought to be large in order to give lim some exercise with the halter before you lead him out. If the lorse belongs to that class which only appears to fear man, you must introduce yourself gently into the stable, room, or yard where the horse is. He will naturally rum from you, and frequently turn ohis head towards you; but you must walk about extremely slow and softly, so that he can see you whenever he turns his head towards you, which he never fails to do in a short time-in a quarter or half an hour. I never knew one to be much longer without turning his head towards me. At the very moment he turns his head, hold out your left hand towards him, and stand perfectly still, keeping your eyes upon the horse, watching his motions, if he make any. If the horse does not stir for ten or fifteen minutes, advance as slowly as possible, and without making the least noise, always holding out your left hand. If the horse makes the least motion when you advance towards him, stop and remain perfectly still until he is quiet. Remain a few moments in this condition, and then advance again in the same slow and almost imperceptible manner. If the horse then stirs again, stop without changing your position. It is very uncommon for the horse to stir more than once after you begin to advance; yot there are some exceptions. He generally keeps 
his eyes steadfast upon you, until you get near enough to touch him on the forehead. When you are thus near to him, raise slowly and by degrees your hand, and let it come in contact with that part just above the nostrils, as lightly as possible. If the horse flinches (as many will), repeat with great rapidity these light strokes upon the forehead, going a little further up towards his ears by degrees, anc descending with the same rapidity until he will le: you handle his forehead all over. Now let the strokes be repeated with more force over all his forehead, descending by lighter strokes to each side of his head, until you can handle that part with equal facility. Then touch in the same light manner, making your hands and fingers play around the lower part of the horse's ears, coming down now and then to his forehead, which may be looked upon as the helm that governs all the rest.

Having succeeded in handling his ears, advance towards the neck, with the same precautions, and in the same manner; observing always to augment the force of the strokes whenever the horse will permit it. Perform the same on both sides of the neck, until he lets you take it in your arms without flinching.

Proceed in the same progressive manner to the sides, and then to the back of the horse. Every time the horse shows any nervousness, return immediately to the forehead, as the true standard, patting him with your hands, and thence rapidly to where you bad alrerdy arrived, always gaining ground a 
considerable distance further on every time this happens. The head, ears, neck, and body being thus gentled, proceed from the back to the root of the tail.

'This must be managed with dexterity, as a horse is never to be depended on that is skittish about the tail. Let your hand fall lightly and rapidly on that part next to the body a minute or two, and then you will begin to give it a slight pull upwards every quarter of a minute. At the same time you continue this handling of him, augment the force of the strokes as well as the raising of the tail, until you can raise it and handle it with the greatest ease, which commenly happens in a quarter of an hour in most horses, in others almost immediately, and in some much longer. It now remains to handle all his legs; from the tail come back again to the head -handle it well, as likewise the ears, breast, neek, \&c., speaking now and then to the horse. Begin by degrees to descend to the legs, always ascending and descending, gaining ground every time you descend, until you get to his feet.

Talk to the horse while you are thus taming him; let him hear the sound of your voice, which at the beginning of the operation is not quite so necessary, but which I have always done in making him lift up his feet. "Hold up your foot," you will say, at the same time lifting up his foot with your hand. He soon becomes familiar with the sounds, and will hold up his foot at command. Then, proceed to the hind feet, and go on in the same manner; and in a short 
time the horse will let you lift them, and even take -them up in your arms.

All this operation is no magnetism, no galvanism; it is merely taking away the fear the horse generally has of man, and familiarizing the animal with lis master. As the horse doubtless experiences a certain pleasure from this handling, he will soon become gentle under it, and show rery marked attachment to his keeper.

THE KIND OF BIT TO BE USED, AND HOW TO USE IT.

In first accustoming a colt to the bit, you should use a large, smooth snaffle, so as not to hurt his mouth, with a bar at each side to prevent it from pulling through either way. This should be attached to the head-stall of your bridle, and put it on your colt without any reins to it, and let him run loose in a large stable or shed, some time, until he becomes a little used to the bit, and will bear it without trying to get it out of his mouth. Repeat this several times, before you do anything more with the colt; and as soon as he will bear the bit, attach a single rein to it, without any martingale. Iou should also have a halter on your colt, or a bridle made after the fashion of a haltor, with a strap to it, so that you can hold or lead him about without pulling much on the bit.

Farmers often put bitting harness on a colt the first thing they do to him, buckling it on as tight as they can draw it, to make him carry his liead high, nnd then turn lim out in a lot, to run half a day at 
a time. This is one of the very worst punishments they can inflict on a colt, and is very injurious to a young horse that has been used to running in pasture with his head down. I have seen colts so injured in this way that they never got over it.

A horse should be well accustomed to the bit before you put on the bitting harness, and when you first bit him you should only rein his head up to the point where he naturally holds it, let that point be high or low; he will soon learn that he cannot lower his head, and that raising it a little will loosen the bit in his mouth. This will give him an idea of raising his head to loosen the bit; and then you can draw the bitting a little tighter every time you put it on, and he will still raise his head to loosen it. By this means you will gradually get his head and neck in the position you want him to carry it, and give him a nice and graceful carriage without hurting him, making him mad, or causing his mouth to get sore. Horses that have their heads drawn up tightly, should not have the bitting on more than fifteen minutes at a time.

\section{HOW TO SADDLE A COLT.}

Any one man who has this theory, can put a saddle on the wildest horse that ever grew, without any help, and without scaring him. The first thing will be to tie each stirrup strap into a loose knot, to make them short and prevent the stirrups from flying about and hitting him. Then double up the skirts and take the saddle under your right arm, so as not to frighten 
him with it when you approach. When you get to him, rub him gently a few times with your hand, then raise the saddle very slowly, until he can see it, and smell, and feel it with his nose. Then let the skirts loose, and rub it very gently against his neck the way the hair lays, letting him liear the rattle of the skirts as he feels them against him; each time a little further backward, and finally slip it over on his back. Shake it a little with your hand, and in less than five minutes you can rattle it about over his back as you please, and pull it off and throw it on again, without his paying much attention to it.

As soon as you have accustomed him to the saddle, fasten the girth. Be eareful how you do this. It often frightens the colt when he feels the girth binding him, and making the saddle fit tight on his back. You should bring up the girth very gently, and not draw it too tight at first, just enough to hold the saddle on. Move him a little, and then girth it as tight as you choose, and he will not mind it.

You should see that the pad of your saddle is all right before you put it on, and that there is nothing to make it hurt him, or feel unpleasant to his back. It should not have any loose straps on the back part of it, to flap about and scare him. After you have saddled him in this way, take a switch in your right hand to tap him up with, and walk about in the stable a few times with your right arm over your saddle, taking hold of the reins on each side of his neck with your right and left hands, thus marching him about in the stable until you teach him the uso 
of the bridle and can turn him about in any direction, and stop him by a gentle pull of the rein. Always caress him, and loose the reins a little every time you stop him.

You should always be alone, and have your colt in some light stable or shed the first time you ride him; the loft should be high, so that you can sit on his back without endangering your head. You can teach lim more in two hours' time in a stable of this kind, than you could in two weeks in the common way of breaking colts, out in an open place. If you follow my course of treatment, you need not run any risk, or have any tromble in riding the worst kind of horse. You take him a step at a time, until you get up a mutual confidence and trust between yourself and horse. First teach him to lead and stand hitched; next acquaint him with the saddle, and the use of the bit; and then all that remains is to get on him without scaring him, and you can ride him as well as any horse.

\section{HOW TO MOUNT THE COLT.}

First gentle him well on both sides, about the saddle and all over, until he will stand still without holding, and is not afraid to see you anywhere about him. As soon as you have him well gentled, get a small block about one foot or eighteen inches in leight, and set it down by the side of him, about where you want to stand to mount him; step up on this, raising yourself very gently. Horses notice every change of position very closely, and if you 
were to step up suddenly on the block, it would be very apt to scare him; but by raising yourself gradually on it, he will see you, without being frightened, in a position very near the same as when you are on his back. As soon as he will bear this without alarm, untie the stirup strap next to you, and put your left foot in the stirrup, and stand square over it, holding your knee against the horse, and your toe out, so as to touch him under the foreshoulder with the toe of your boot. Place your right hand on the front of the saddle, and on the opposite side of you, taking hold of a portion of the mane and reins (they hang-loosely over his neck), with your left hand, then gradually bear your weight on the stirrup, and on your right hand, until the horse feels your whole weight on the stirup; repeat this several times, each time raising yourself a little higher from the block, until he will allow you to raise your leg over his croup, and place yourseli in the saddle. Another, and in some cases a better way of mounting, is to press the palm of your right hand on the off-side of the saddle, and as you rise lean your weight on it. By this means you can mount with the girths loose, or without any girths at all.

There are three great advantages in having a block to mount from. First, a sudden change of position is very apt to frighten a young horse that has never been handled; he will allow you to walk to him, and stand by his side without scaring at you, because you have gentled him to that position; but 
if you get down on your hands and knees and crawl towards him, he will be very much frightened: and upon the same principle, he would frighten at your new position if you had the power to hold yourself over his back without touching lim. Then the first great advantage of the block is to gradually gentle him to that new position in which he will see you when you ride him. Secondly, by the process of holding your weight in the stirrups, and on your hand, you can gradually accustom him to your weight, so as not to frighten him by having him feel it all at once. And, in the third place, the block elevates you so that you will not have to make a spring in order to get on the horse's back, but from it you can gradually raise yourself into the saddle. When you take these precautions, there is no horse so wild but what you can mount him without making him jump. I have tried it on the worst horses that could be found, and have never failed in any case. When mounting, your horse should always stand without being held. A horse is never well broke when he has to be held with a tight rein when mounting; and a colt is never so safe to mount as when you see that assurance of confidence, and absence of fear, which cause him to stand without holding.

HOW TO RIDE THE COLT.

When you want him to start, do not touch him on the side with your heel, or do anything to frighten him and make him jump. But speak to him kindly, 
and if he does not start, pull him a little to the left until he starts, then let him walk off slowly with the reins loose. Walk him around in the stable a few times until he gets used to the bit, and you can turn him about in every direction and stop him as you please. It will be well to get on and off a good many times until he gets perfectly used to it before you take him out of the stable. After you have trained him in this way, which should not take more than two or three lours, you can ride him anywhere you choose without ever having him jump or make an effort to throw you.

When you first take him ont of the stable, be very gentle with him, as he will feel a little more at liberty to jump or run, and be easier frightened than he was while in the stable; but you will nevertheless find him pretty well broke, and will be able to manage him without trouble or danger.

When you first mount a colt, take a little the shortest hold on the left rein, so that if anytling frightens him, you can prevent him from jumping by pulling his head around to you. This operation of pulling a horse's head around against his side, will prevent him from jumping ahead, rearing up, or running away. If he is stubborn and will not go, you can make lim move by pulling his head around to one side, when whipping him would have no effect. And turning lim around a few times will make him dizzy, and then by letting him have his head straight, and giving him a little touch with the whip, he will go along without any trouble. 
Never use martingales on a colt when you first ride him; every movement of the hand should go right to the bit in the direction in which it is applied to the reins, without a martingale to cliange the direction of the force applied. You can guide the colt much better without it, and teach him the use of the bit in much less time. Besides, martingales would prevent you from pulling his head round if he should try to jump.

After your colt has been ridden until he is gentle and well accustomed to the bit, you may find it an advantage, if he carries his head too high or his nose too far out, to put martingales on him.

You should be careful not to ride your colt so far at first as to heat, worry, or tire him. Get off as soon as you see he is a little fatigued; gentle him and let him rest; this will make lim kind to you, and prevent him from getting stubborn or mad.

\section{TO BREAK A HORSE TO HARNESS.}

Take him in a tight stable, as you did to ride him; take the harness and go through the same process that you did with the saddle, until you get him familiar with them, so you can put them on his back and rattle them about without his caring for them. As soon as he will bear them, put on the ines, caress lim as you draw them over him, and drive him about in the stable till he will bear them over his hips. The lines are a great aggravation to some colts, and often frighten them as much as if you were to raise a whip over them. As soon as he 
is familiar with the harness and lines, take him out and put lim by the side of a gentle lorse, and go through the same process that you did with the "balking horse. Always use a bridle without blinds when you are breaking a horse to harness.

\section{HOW TO HITCH A HORSE IN A SULKY.}

Lead lim to and around it; let him look at it, touch it with his nose, and stand by it.until he does not care for it; then pull the shafts a little to the left, and stand your horse in front of the off wheel. Let some one stand on the right side of the horse and hold him by the bit, while you stand on the left side, facing the sulky. This will keep him straight. Run your left hand back and let it rest on his hip, and lay hold of the shafts with your right, bringing them up very gently to the left hand, which still remains stationary. Do not let anything but your arm touch his back, and as soon as you have the shafts square over him, let the person on the opposite side take hold of one of them, and lower them very gently to the shaft bearers. Be very slow and deliberate about hitching; the longer time you take the better, as a general thing. When you have the shafts placed, shake them slightly, so that he will feel them agaiust each side. As soon as he will bear them without scaring, fasten your braces, \&c., and start him along very slowly. Let one man lead the horse to keep him gentle, while the other gradnally works back with the lines till he can get behind and drive him. After you have driven him in 
this way a short distance, you can get into the sulky, and all will go right. It is very important to have your horse go gently when you first hitch him. After you have walked him awhile, there is not half so much danger of his scaring. Men do very wrong to jump up behind a horse to drive him as soon as they have him hitched. There are too many things for lim to comprehend all at once. The shafts, the lines, the harness, and the rattling of the sulky, all tend to scare him, and he must be made faniliar with them by degrees. If your horse is very wild, I would advise you to put up one foot the first time you drive lim.

\section{TAMING A HORSE WITH VICIOUS HABITS.}

Having given full instructions relative to my system of dealing with young colts, I will now proceed to detail the plan of operations for taming or subduing wild or vicious horses. 'The principles of this

- method are the same as those in managing coltskindness and gentleness-but the practice differs. When you desire to subdue a horse that is very wild, or has a vicious disposition, take up one fore-foot and bend his knee till his hoof is bottom upwards, and nearly touching his body; then slip a loop over his knee, and shove it up until it comes above the pastern-joint, to keep it up, being careful to draw the loop together between the hoof and pastern-joint with a second strap of some kind to prevent the loop from slipping down and coming off. This will leave the horse standing on three legs; you can 
now handle him as you wish, for it is utterly impos sible for him to kick in this position. There is something in this operation of taking up one foot, that conquers a horse quicker and better than any. thing else you can do to him; and there is no pro cess in the world equal to it to break a kicking horse, for by conqering one member, you conquer, to a great extent, the whole horse.

You can do anything you wish with the horse in this condition, as when he becomes convinced of his incapacity to cope with man, he will abandon all antagonistic demonstrations, and become willing to obey, and generally docile. Operate on your horse in this manner as often as the occasion requires, and you will soon find him as gentle as his nature will permit him to be. By these means the most vicious, uneasy, unruly or fretful horse may be cured, though it depends upon the age and disposition of the animal how long it will take to make him amiable. When you first fasten up a horse's foot, he will sometimes get very mad, and strike with his knee, and try every possible way to get it down; but as he cannot do that, he will soon give up.

Conquering a horse in this manner is better than anything else you could do, and leaves him without any possible danger of hurting himself or you either; for after you have tied up his foot, you can sit down and look at him until he gives up. When you find he is conquered, go to him, let down his foot, rub his leg with your hand, caress him, and let him rest a few minutes; then put it up again. Repeat this a 


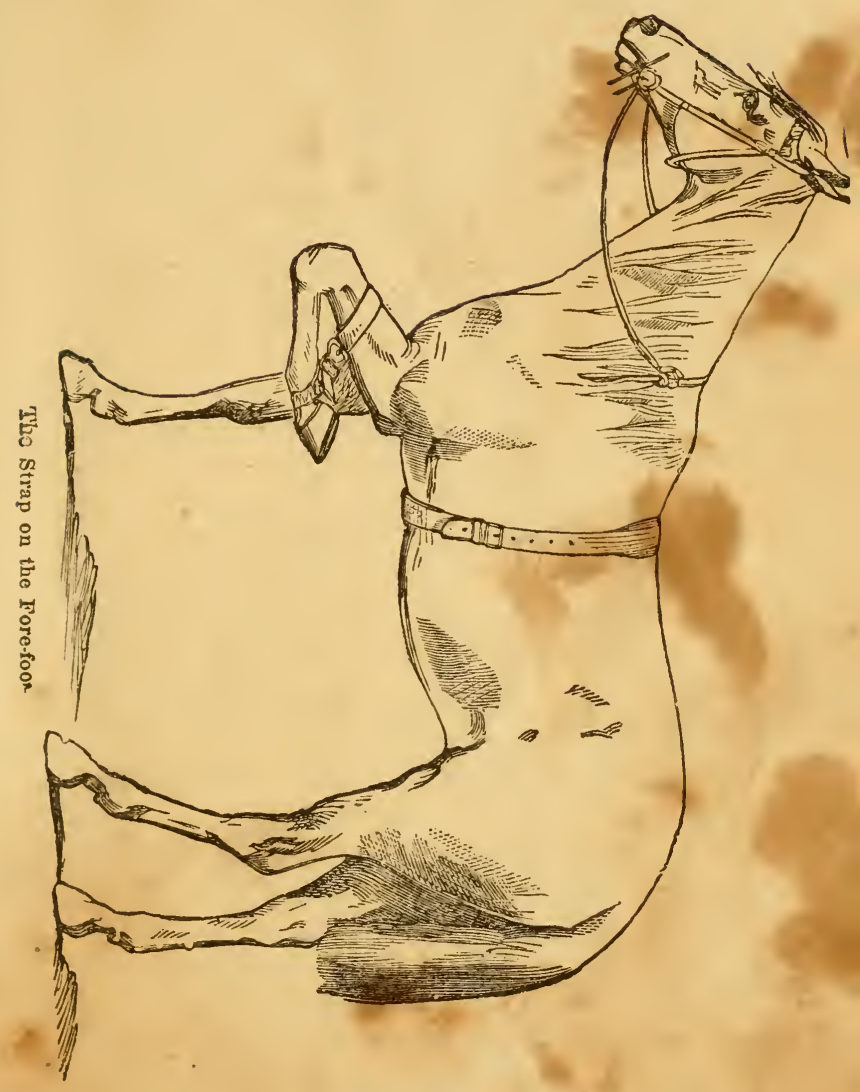


few times, always putting up the same foot, and he will soon learn to travel on three legs, so that you can drive him some distance. As soon as he gets a little used to this way of trareling, put on your harness and hitch him to a sulky. If he is the worst kicking horse that ever raised a foot, you need not te fearful of his doing any damage while he has one foot up; for he cannot kick, neither can he run fast enough to do any harm. And if he is the wild. est horse that crer had harness on, and has run away every time he has been harnessed, you can now hitch him to a sulky and drive him as you please. If he wants to run, you can let lim have the lines, and the whip too, with perfect safety; for he can go but a slow gait on three legs, and will soon be tired and ready to stop; only hold him enough to guide him in the right direction, and he will soon be tired and willing to stop at the word. Thus you will effectually cure him at once of any further notion of running off. Kicking horses have always been the dread of ererybody; you always hear men say, when they speak about a bad horse, "I don't care what he does, so he don't kick." This new mode is an effectual cure for that worst of all habits. There are plenty of ways by which you can hitch a kicking horse, and force him to go, tliongh he kicks all the time; but this don't have any good effect towards breaking him, for we know that horses kick because they are afraid of what is behind them, and when they kick against it and it hurts them, they only kick the harder; and this will hurt 
them still more and make them remember the scrape much longer, and make it still more difficult to persuade them to have any confidence in anything dragging behind them ever after. But by this new method you can hamess them to a rattling sulky, plow, wagon, or anything else in its worst shape. They may be frightened at first, but cannot kick or do anything to hurt themselves, and will soon fird that you do not intend to hurt them, and then they will not care anything more about it. You can then let down the leg and drive along gently without any further trouble. By this new process a bad kicking horse can be learned to go gentle in harness in a few hours' time.

\section{HOW TO MAKE A HORSE LIE DOWN.}

Everything that we want to teach the horse must be commenced in such a way as to give him an idea of what we want him to do, and then be repeated till he learns it perfectly. To make a horse lie down, bend his left fore-leg and slip a loop over it, so that he cannot get it down. Then put a surcingle around his body, and fasten one end of a long strap around the other fore-leg, just above the hoof. Place the other end under the before-described surcingle, so as to keep the strap in the right direction: take a short hold of it with your right hand; stand on the left side of the horse; grasp the bit in your left hand, pull steadily on the strap with your right; bear against his shoulder till you cause him to move. As soon as he lifts his weight, your pulling will 
raise the riher joot, and he will have to come on his knees. Keen the strap tight in your hand, 80 that he cannet straighten lis leg if he rises $u_{2}$ ). IIold lim in this position, and turn lis head towards you; bear against his side with your shoulder, not hard, but with a steady, equal pressure, and in about ten minutes he will lie down. As soon as he lies down, he will be completely conquered, and you can handle him as you please. 'Take off the straps, and straighten out his legs; rub him lightly about the face and neck with your hand the way the hair lies; handle all his legs, and after lie has lain ten or twenty minutes, let him get up again. After resting him a short time, make him lie down as before. Repeat the operation three or four times, which will be suffcient for one lesson. Give lim two lessons a day, and when you have given him four lessons, he will lie down by taking hold of one foot. As soon as lie is well broken to lie down in this way, tap him on the opposite leg with a stick when you take hold of his foot, and in a few days he will lie down from tha mere motion of the stick.

\section{RECAPITULATION, AND MINUTE DIRECTIONS.}

In practicing the foregoing method upon a colt, lic should be first accustomed to be handled, and taught to lead easily. In approaching a spiteful or viciors horse, you had better make your advances with a halfopened door between you and lim; gradually mako his acquaintance, and teach him that you do not caro for his open mouth; but a regular biter must be gag. 


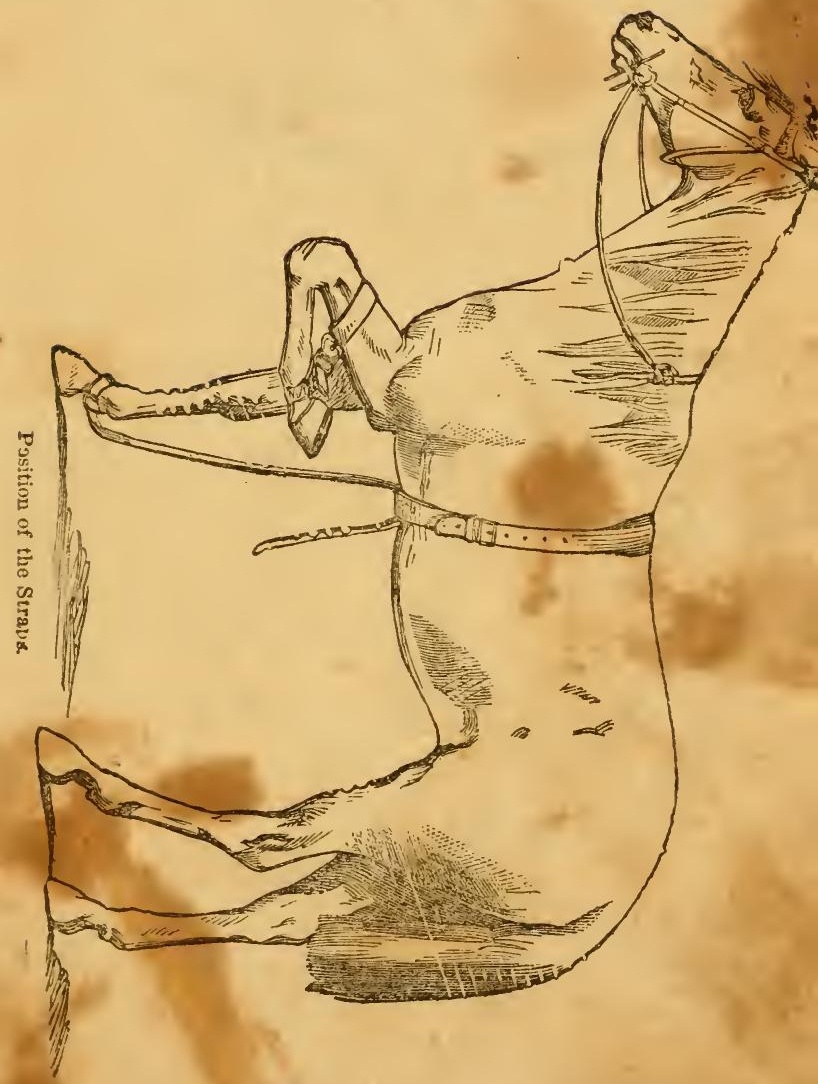


ged with a wooden bit made for the purpose, so large that he cannot close his mouth. Here is the kind of bit to be used :

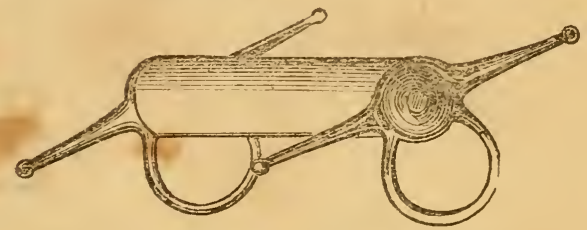

Of course there is no difficulty in handling the leg of a quiet horse or colt, and by ennstantly working from the neck down to the fetlock, you may do what you please. But many horses, and even colts, have a most dangerous trick of striking out with their fore-legs. There is no better protection against this than a cart-wheel. The wheel may either be used loose, or the animal may be led up to a cart loaded with hay, when the horse-tamer can work under the eart through one of the wheels, while the colt is vibbling the load.

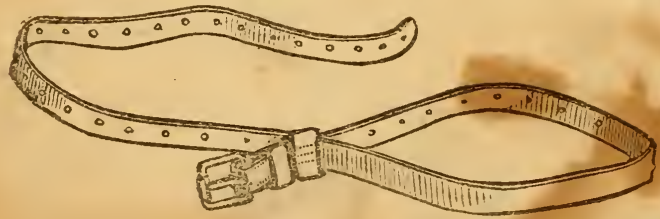

Strap No. 1.

Having, then, so far soothed a colt that he will permit you to take up his legs without resistance, take the strap No. 1, pass the tongue through the loop under the buckle so as to form a noose, slip it 
over the near fore-leg and draw it close up to the pastem-joint, and fasten it as represented in the engraving. But you must not be rash in lifting the leg, and employ.but little force in doing so. It is better to wait until he lifts it willingly by the use of gentle means. Do not get out of temper if you have to make a dozen ineffectual attempts to raise it. The near fore-leg being securely strapped, and the horse secured from biting, if necessary, with the wooden bit, (described elsewhere,) you will then make him hop about as before stated. 'This he will learn to do easily. The trainer must, however, take care to keep behind his horse's shoulder and walk in a circle, or he will be likely to be struck by the animal's head or strapped up leg.

A horse can hop on three legs for two or three miles, if you give him his own time, and no plan that has ever been tried is equal to this for curing a kicking or balky horse. After you have tired him out pretty well in this manner, you proceed to make him lie down, which process requires considerable patience and skill. For this purpose take strap No. 2, and making a loop with it put it round the off foreleg. With a very quiet horse this can easily be done; with a wild or vicious horse you may have to make him step into it; at any rate, when once the off fore-leg is caught in the noose it must be drawn tight round the pastern-joint. Then put a stout glove on your right hand, pass the strap through the belly part of the surcingle, take a firm short hold of it with your gloved right hand, standing 
close to the horse behind his shoulders, and with your left hand take hold of the near rein; by pulling the horse gently to the near side he will bo almost sure to hop; if he will not, he must be led.

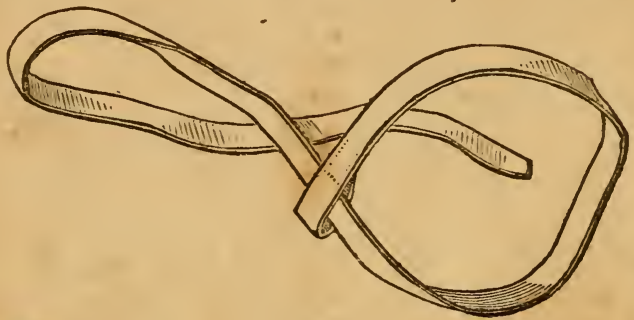

Strap No. 2 .

The moment he lifts up his off fore-foot, you must draw up strap No. 2 tightly and steadily. The horse will then go down on his knees, for if you hold the strap tight he will not be able to stretch out his foot again. As soon as a horse recovers from his astonishment at being brought to his knees, he begins to resist; that is, he rears up on his hind legs, and springs about in a manner that will sometimes alarm the trainer. [See picture of horse struggling on page 39.] During these struggles you must not try your strength against the horse's strength, but merely follow him about, holding the strap just tight enough to prevent him from nutting out his off foreleg. As long as you keep close to him and behind his shoulders, you are in very little danger. The bridle in the left hand must be used like stecring lines, by pulling to the right or left as nccrsion re. quires: the lorse, turning on his lind legs, may be 


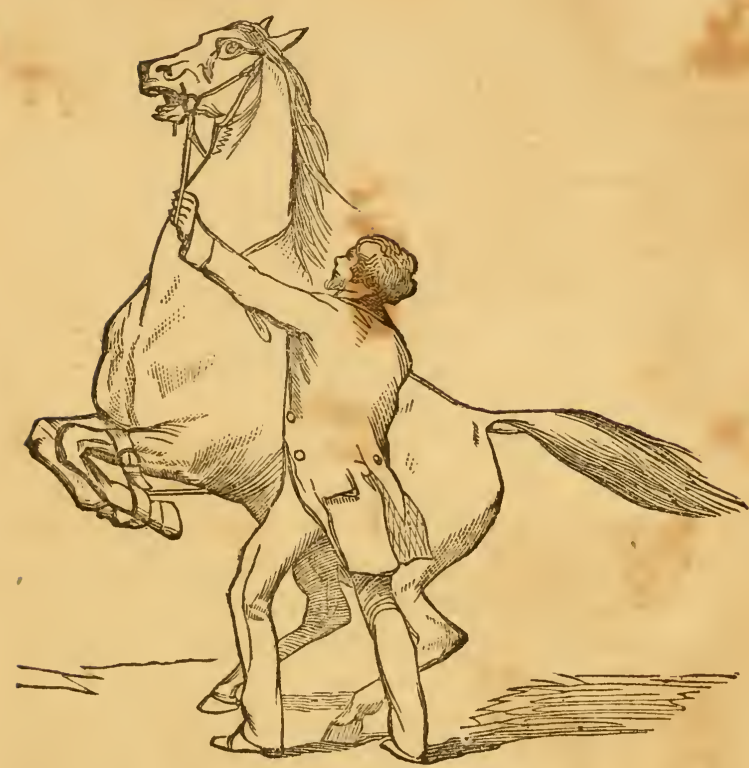

fatigued by being forced to walk backwards. The strap passing through the surcingle keeps, or onght to keep, the trainer in his right place-he is not to pull or in any way fatigue himself more than he can help, but, standing upright, simply follow the horse

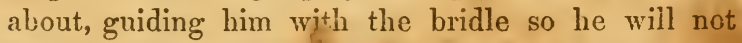
precipitate himself against the side of the stable or room in which you are exercising him. When held and guided properly, he will scon sink down. Cornfed horses will hold out longer than grass-fed ones, and the most energetic horse will scarcely struggrle 
more than ten or fifteen minutes. Usually, at the end of eight minutes' violent struggles, the animal sinks forward on his knees, sweating profusely, with heaving flanks and shaking tail. If he still resists he may be forced by the bit to walk backwards and forwards, but this is generally unnecessary, as by pushing gently at his shoulder, or b: pulling steadily the off-rein, you can get him to fall, in the one case on the near side, in the other on the off side; but this assistance should be so slight that the horse will not attempt to resist it. The horse will often make a final spring when you think he is quite beaten; but at length he slides over, and lies down, panting and exhansted, on his side. If he is a pretty spirited animal, take advantage of the moment to tie up the off fore-leg to the surcingle, as securely as the other, in a slip-loop knot.

Now let your horse recover his wind, and then encourage him to make a second fight. It will often be more stubborn and more fierce than the first. The object of this tying-up operation is, that he shall thoroughly exhaust without hurting limself, and that he shall come to the conclusion that it is you who, by your superior strength, have conquered him, and that you are always able to conquer him.

Under the old rough-riding system, the most vicious horses were occasionally conquered by daring men with firm seats and strong arms, who rode and flogged them in乞o stiljection; but these conquests were temporary, and usually personal; with every stranger, the animal womld begin his game again. 


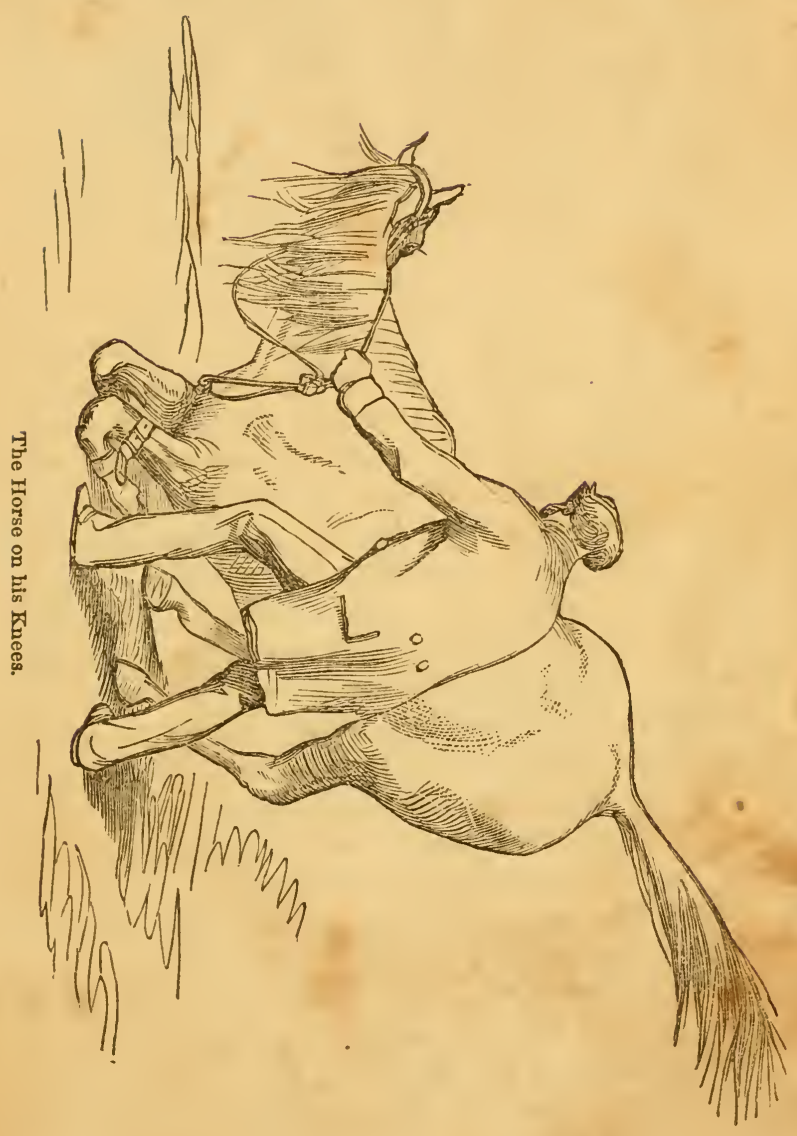


One advantage of this system is, that the horse is allowed to exhaust himself under circumstances that render it impossible for him to struggle long enough to do himself any harm. It has been suggested that a blood-vessel would be likely to be broken, or apoplexy produced by the exertion of leaping from the hind legs; but, up the present time, no accident of any kind has been reported.

\section{TREATMENT OF THE HORSE AFTER HE IS DOWN.}

- If the horse has fought hard in going down, he will then usually lie perfectly still, and you can gentle him, scrape the sweat off, and rub him down, smoothing the hair of his legs, and drawing the fore one straight out. In this position you have the opportunity of making him perfectly familiar with you, and the more you fondle him and reconcile him to you the better. If you are treating an unbroken colt in this way, you may now mount his back, and thus, by finding out that you mean him no harm, he will learn to submit to being mounted when he stands up. You can also lay a saddle or harness on him and familiarize him with those articles. His head, tail and legs should now be handled with freedoin, caressing and talking to him all the while. If he has hitherto resisted shoeing, handle all his legs with a view to accomplish it, and if he attempts to resist, continue until you subdue him, speaking to him with a voice of authority. If he is a bad kicker you may be obliged to confine his fore-legs; and with those tied, you may spend an hour in 





handling his legs, tapping the hoofs with your hand or a hammer-all this to be done in a firm, measured, soothing manner; only now and then, if he resist, krying, as you paralyze him with the ropes, "Wo!" in a determined manner. It is by this continuai soothing and handling that you establish confidence between the horse and yourself. After patting him as much as you deem needful, say for ten minutes or a quarter of an hour, you may encourage him to rise. Some horses will require a good deal of helping, and it may be necessary to draw out their forelegs before them. The handling of the limbs of colts in this condition, particularly requires caution. A colt tormented by flies, will kick forward nearly up to the fore-legs. If a horse, unstrapped, attempts to rise, you may easily stop him by taking hold of a fore-leg and doubling it back to the strapped position. If by chance he should be too quick, don't resist, for it is an essential principle of this system nerer to enter into a contest with a horse unless you are certain to be victorious. In all these operations you must be calm, and never be in a hurry, or in a passion.

The principle established by this mode of treatment is that you show no violence to frighten the horse, and yet you force him to submit to your will, caressing himwen he assents and gently forcing him when he does not. Repeated lessons will convince the most vicious horse that youre his master, and your gentle caresses consequent on his submission will at the same time give him confidence in 
you. It has been suggested that a novice should begin his practice on a gentle horse that he can handle at pleasure, and the plan is a good one. He may thus become familiar with the process before trying it, in earnest, on a vicious or unbroken animal.

A singular fact in illustration of the beanty of this treatment of refractory lorses is mentioned in an English periodical. A beautiful gray mare, which had been fourteen years in the band of one of the Life Guards regiments, and consequently at least seventeen years old, would never submit quietly to have her hind-legs shod; the farriers had to put a twitch on her nose and ears, and tie her tail down: even then she resisted violently. After three days' treatment similar to that above described, she was easily shod with her head loose. And this was not done by a trick, but by proving to her that she could not resist even to the extent of an inch, and that no harm was intended her.

\section{HOW TO MANAGE BALKY HORSES.}

Horses know nothing about balking until they are forced into it by bad management. When a horse balks in harness, it is generally from some mismanagement, excitement, confusion, or from not knowing how to pull, but seldom from any unwillingness to perform all that he understands. High-spirited freegoing horses are the most sulject to balking, and only so because drivers do not properly understand Low to manage this kind. A free horse in a team may be so anxious to go, that when he hears the 
word he will start with a jump, which will not nove the load, but give him so severe a jerk on the shoulders that he will fly back and stop the other horse. The teamster will continue his driving without any cessation, and by the time he lias the slow horse started again, he will find that the free horse has made another jump, and again flown back. And now he has them both badly balked, and so confused that neither of them knows what is the matter, or how to start the load. Next will come the slashing and cracking of the whip, and hallooing of the drirer, till something is broken, or he is through with his course of treatment. But what a mistake the driver commits by whipping his horse for this act! Reason and common serse should teach him that the horse was willing and auxious to go, lut did not know how to start the load. And should he whip lim for that? If so, he should whip him again for not knowing how to talk. A man that wants to act with reason should not fly into a passion, but should always think before he strikes. It takes a steady pressure against the collar to move a load, and you cannot expect him to act with a steady, determined purpose while you are whipping him. There is hardly one balking horse in five hundred that will pull truly from whipping: it is only adding fuel to fire, and will make him more liable to balk another time. You always see horses that have been balked a few times, tum their heads and look back as soon as they are a little frustrated. This is because they have been whipped, and are afraid of what is behind 
them. This is an invariable rule with balky horses, just as much as it is for them to look around at their sides when they have the bots; in either case they are deserving of the same sympathy, and the same kind of rational treatment.

When your horse balks, or is a little excited, or if he wants to start quickly, or looks around and don't want to go, there is something wrong, and he needs kind treatment immediately. Caress him kindly, and if he don't understand at once what you want him to do, he will not be so much excited as to jump and break things, and do everything wrong through fear. As long as you are calm, and can keep down excitement of the horse, there are ten chances to have him understand you, where there would not be one under harsh treatment; and then the little flare up would not carry with it any unfarorable recollections, and he would soon forget all about it, and learn to pull true. Almost every wrong act the horse commits is from mismanagement, fear or excitement; one harsh word will so excite a nervous liorse as to increase his pulse ten beats in a minute.

When we remember that we are dealing with dumb brutes, and reflect how difficult it must be for them to understand our motions, signs and language, we should never get out of patience with them because they don't understand us, or wonder at their doing things wrong. With albour intellect, if we were placed in the horse's situation, it would be difficult for us to understand the driving of some 
foreigner, of foreign ways and foreign language. We should always recollect that our ways and language are just as foreign and unknown to the horse as any language in the world is to us; and should try to practice what we could understand were we the horse, endeavoring by some simple means to work on his understanding rather than on the different parts of lis body. All balked horses can be started true and steady in a few minutes' time; they are willing to pull as soon as they know how; and I never yet fourd a balked horse that I could not teach to start his load in fifteen, and often in less than three minutes' time.

Almost any team, when first balked, will start kindly if you let them stand five or ten minutes, as though there was nothing wrong, and then speak to them with a steady roice, and turn them a little to the right or left so as to get them both in motion before they feel the pinch or the load. But if you want to start along a team that you are not driving yourself, that has been balked, fooled, and whipped for some time, go to them and hang the lines on their hames, or fasten them to the wagon, so that they will be perfectly loose; make the driver and spectators, if there are any, stand off some distance to one side, so as not to attract the attention of the horses; unloose their check reins, so that they can get their heads down, if they choose; let them stand a few minutes in this condition, until you can see that they are a little composed. While they are standing you should be about their heads gentling 
them; it will make them a little more kind, and the spectators will think you are doing something that they do not understand, and will not learn the secret. When you have them ready to start, stand before them, and as you seldom have but one balky hoise in a team, get as near in front of him as you can, and if he is too fast for the other horse, let his nose come against your breast; this will keep himsteady. for he will go slow rather than run on you; turn them gently to the right, with the wagon; have it stand in a favorable position for starting out, letting them pull on the traces as far as the tongue will let them go; stop them with a kind word, gentle them a little, and turn them back to the left, by the same process. You will have them under your control by this time, and as you turn them again to the right, steady them in the collar, and you can take them where you please.

There is a quicker process that will generally start a balky horse, but not so sure. Stand him a little ahead, so that his shoulder will be against the collar, and then take up one or his fore feet in your hand, and let the driver start them, and when the weight comes against his shoulders, he will try to stop-then let him have his foot, and he will go right along. If you want to break a horse from balking that has long been in that habit, you ought to set a day apart for that purpose. Put him by the side of some steady horse; have check lines on then; tie up all the traces and straps, so that there will be nothing to excite them; do not rein them 
up, but let them have their heads loose. Walk them about together for some time as slowly and lazily as possible; stop often and go up to the balky horse and gentle him, but keep him just as $\mathrm{q}_{1}$ uiet as you can. He will soon learn to start off at the word, and stop whenever you tell him.

As soon as he performs right, hitch him to an empty wagon. It would be well to shorten the stay chain behind the steady horse, so that if it is necessary he can take the weight of the wagon the first time you start them. Do not drive but a few rods at first; watch your balky horse elosely, and if you see that he is getting excited, stop him before he stops of his own accord, caress him a little, and start again. As soon as they go well, drive them over a small hill a few times, and then over a large one, occasionally adding a little load. 'I'his process will make any horse true to pull.

CHOKING, A MEANS OF SLBDUING THE HORSE.

This is another method of conquering a skittish, stubborn or refractory horse. It is resorted to in cases where the measures before described fail to produce the desired effect. The principles on which the plan of choking are based, are, that you must make a powerful appeal to the intelligence of the animal by physical means before you can subdue him. Now we know that most animals, in fighting; seize each other by the throat, and that a dog thus held by his antagonist for a few minutes, on being released, is often so thomughly eowed that no human 
artifice can induce him to again resume the unequal contest. It is, then, reasonable to suppose that choking will have a similar effect on the horse. When it can be done witlout injuring the animal, it is an easy mode of subduing him, for by its operation he becomes docile, and will thereafter receive any instruction which he can be made to understand. Teaching the horse, by this means, to lie down at our bidding, tends to keep him permanently gentle towards man, for it is a perpetual reminder of his subdued condition.

It requires a good deal of practice to tame a horse successfully by choking; also a nice judginent to know when he is choked sufficiently, as there is a bare possibility that he might get more than would be good for him. We advise persons not perfectly familiar with a horse to resort rather to the strapping and throwing-down process, unless the animal to be operated upon is so vicious and intractible that he cannot be cured by it. It is the fault of most people who have owned a horse to imagine that they are experts in his management; while, on the contrary, many professional horsemen are the very worst parties to attempt his subjugation.

In practicing the choking process, retire with the animal to be operated upon into a close stable, with plenty of litter upon the floor (tanbark or sawdust is preferable). In the furst place fasten up the left fore-leg with strap No. 1, (p. 36,) in such a manner that it will be permanentiy secured. 'Then take a broad strap with a buekle. n buckls frome at the end, and 




pass it around the neck just back of the jaw-bone, in the position given in the engraving. Draw the strap as tight as possible, so tight as to almost arrest the horse's breathing. The strap nust not be buckled, but held in this position to prevent slipping back. The animal will struggle for a few minutes, when he will become perfectly quict, overpowered by a sense of suffocation; the veins in his lhead will swell; his eyes lose their fire; his knees totter and become weak; a slight vertigo will cnsue, and he will grow gradually exhausted. By now backing lim around the stable, he will come down on his lknees, in which position it is an easy matter to push him on his side, when his throat should be released. You must now operate with the horse in the same manner as described after getting him down by straps. Speak kindly to him, rub him gently the 
way the hair lies, fondle him in various ways, and he will be completely subdued. You should not attempt to fondle him, however, until you are satisfied that he has got over the excitement which the choking caused in lim. It is ouly necessary in extreme cases to repeat the operation of clioking, as no horse can effectually resist its terrible effects.

It should be constantly borne in mind that the operator must not be boisterous or violent, and that the greatest possible degree of kindness is absolutely essential. When the horse is prostrate he should be soothed mitil his eyes show that he has become perfectly tranquil.



Another process of choking is described by the above engraving. After tying up your horse to the manger, make friends with him by some one of the coaxing processes heretofore given, and when you get him in thorough good humor with you, begin the 
choking by seizing him on the throat near the jaw, at the same time holding on to his mane with your left hand. When you have exhausted him suffiiciently, let go the mane and rap him gently on the fore-legs until he lies down; or you may touch him with your foot instead. After he is down, rub lim gently, speak kindly to him, and as soon as he is properly composed, fondle and caress him.

\section{GENERAL RULES, AND REMARKS.}

In taming the horse either by choking or any of the other processes here given, the following rules should be observed: First-When forcing down the horse in either of the ways deseribed, be careful of lis neck. Do not let him fall upon that, or he may break it, as the spine of the horse is easily broken. Second-Do not force him down violently under any circumstances. The way to get lim down is by patiently choking him and waiting until he goes down easily and from sheer exhaustion. Thirdly-Keep him very quiet by stroking or patting lim with your hand in a gentle and delicate manner, until he is entirely over the excitement which your operations have caused in him. You can generally tell when he is appeased by the expression of his eyes. Fourtlly-In backing the liorse, never use violence. Hold the halter and of rein in your left hand, while managing him to bring him down.

In teaching a horse to follow you, and in curing him of kicking or biting, or balking, or indeed any 
bad habit, the choking operation is resorted to with equal success as in the case of taming or breaking. If he continues stubborn, you have only to repeat the operation, giving him one or two lessons a day, and in a short time he will be perfectly subdued. A young horse learns to obey quicker than an older one. When you get a horse down by any of the processes we have mentioned, a quarter of an hour or twenty minutes is ample time to keep him prostrate for the purpose of subjugation. Breathing into a horse's nostrils when he is down is practiced by some horse-tamers, and this is undoubtedly a soothing operation, as it brings you into close contact with the animal, thus giving him an opportunity of examining you with lis nose-a process peculiur to horses. You should always litter your stable well when you perform these operations of flooring the horse. Clean straw or tanbark, or anything to make a soft stable bottom will answer.

\section{HOW TO MAEE A HORSE FOLLOW YOU.}

Turn him out into a large stable or shed, where there is no chance to get out, with a halter or bridle on. Go to him and gentle him a little; take hold of the haltex and turn him towards you, at the same time touching him lightly over the hips with a long whip. Lead him the length of the stable, rubbing: him on the neck, saying, in a steady tone of voice, as you lead him, "Come along, my boy !" or use his name instead of my boy, if you choose. Every time you turn, touch him slightly with the whip, to make 
him step close up to you, and then caress him with your hand. He will soon learn to hurry up to escape the whip, and be caressed, and you can make him follow you around withont taking hold of the halter. If he should stop and turn from you, give him a few sharp cuts about the hind legs, and he will soon turn his head towards you, when you must always caress him. I few lessons of this kird will make him rum after you, when he sees the motion of the whip-in twenty or thirty mimutes he will follow you around the stable. After you have given him two or three lessons in the stable, take him in a small lot and train him; and from thence you can take him into the road, and make him follow you anywhere, and run after you.

TO MAKE A HORSE STAND WTHHOTT HOIOING. "

After you have well broken him to follow you, stand him in the center of the stable-begin at the head to caress him, and gradually work backwards. If he moves, gives him a cut with the whip, and put him back to the same spot from where he started. If he stands, caress him as before, and continue gentling him in this way until you can get around him without making him move. Keep walking round him, increasing your pace, and only touch him occasionally. Enlarge your circle as you walk around, and if he then moves, give him another cut with the whip, and put him back to his place. If he stands, go to him frequently and caress him, and then walk round him again. Do not keep lim in 
one position too long at a time, but make him come to you occasionaily, and follow you around the stable. Then stand him in another place, and proceed as before. You should not train him more than half an hour at a time.

\section{TO PREVENT A HORSE FROM SCARING.}

This process is very simple. Whenever a horse scares at objects on going along the road, always stop him, and let him face the object. Lead him slowly towards it, and let him touch it with his nose. Take the pains to do this on every occasion, and it will soon break him entirely. If your horse is frightened.at an umbrella, you can soon learn him to be used to that. Gro into the stable with him, and first, let him look at the umbrella before it is opened-let him touch it with his nose. Open it a little way, and then let him see it, and finally open it wide. By ordinary patience you can soon learn the horse to have the umbrella opened suddenly in his face, without his being afraid of it. By a sinilar treatment you can break any horse from scaring at almost anything that may look frightful to him. If you wish to make a trial of this theory, just take a horse into the stable, and let him examine the frightful object a fow minutes, after his mode of examining things, and you will be perfectly satisfied. There is a singular fact connected with taming the horse that I would have never believed if I had not tried it. If you accustom him to any particular olject by showing it to him on one side, only, he will 
not be afraid when he sees it with the eye on that side, but he will be afraid if you approach him with it on the other side. It is therefore necessary to pacify him on both sides in all cases. After you have accustomed him to the umbrella, or whatever you may wish to make him familiar with, on his right side, repeat the operation on the left side in the same manner as if you had not approached him at all.

BLINDS, OR BLINKERS.

All my experience with and observation of horses, proves clearly to me that blinkers should never be used, and that the sight of the horse, for many reasons, should not be interfered with in any way. Horses are only fearful of objects which they do not understand, or are not familiar with, and the eye is one of the principal mediums by which this understanding and this familiarity are brought about. The horse, on account of his very amiable nature, can be made in the course of time to bear almost anything in any shape; but there is a quicker process of reaching his intelligence than that of wearing it into him through his skin and bones. However wild or nervous a horse may be, he. can be taught in a very short time to understand and not to fear any object, however frightful in appearance. Horses can be broken in less time, and better, vrithout blinkers; but horses that have always worn them will notice the sudden change, and must be treated carefully the frst drive. After that they will drive better with- 
out the blinkers than with. I have proved by my own experiments that a horse broken without blinkers can be driven past any omnibus, cab or carriage, on a parallel line as close as it is possible for him to go, without ever wavering or showing any disposition to dodge. I have not in the last eight or ten years, constantly landling horses, both wild and nervous, ever put blinkers on any of them, and in no case have they ever shied at passing objects.

'The horse's eye is the life and beauty of the animal, as well as the index of all his emotions. It tells the driver, in the most impressive characters, what the horse's feelings are. By it he can tell the first approach of fear in time to meet any difficulty; he can tell if he is happy or sad, hungry or weary. The horse, too, when permitted to sec, uses his eyes with great judgment. He sees better than we do. He can measure distances with his eyes better than we can, and, if allowed free use of them, would often save himself, by the quickness of his sight, from collisions when the driver would fail to do so by a timely pull of the reins. It would also save many accidents to pedestrians in the streets, as no horse will run on to any person that he can see. Blinkers are rapidly going out of use in the United. States, and I have yet to find the man who, having once left them off, could ever be persuaded to put them on again. 'They are an unnecessary and injurious incumbrance to the horse, and in years hence will be a thing to be read of as one of the follies happily reformed in the nineteenth century. 
RULES TO BE OBSERVED IN FEEDING.

Never give a horse whole grain. By bruising it, and wetting it with soft water, you save thirty per cent. of its nutricious effects. Steam it in preference to wetting, if you have facilities for loing so. Feed your horse two hours before he begins his day's work. Give lum the largest feed at night. Never tie him up to a rack; it is cruel to thus prevent a ho:se from lying $f \circ x \mathrm{n}$ when he is tired. 'The best way is to take awc! your rack altorether, and arrango jour stable so as to inake it unnecessary to tie up the horse The stable shculd always be dry and well littered. Never gire rour horse hard water to drink, if soft water is to he had. If you cannot, get soft water, uraw the havd. water out of the well two hours before you ict him drink it. Beans should be full a year old before tley are fit to feed to horses; they should be bruised, tie same as grain, not ground. Youatt recommends for Le"se feed, the following mixture: Cut hay, \&wo parts; cut straw, threc parts-add to this a quantity of bruisal teans, oats, or other grain—wet the whole with scit water, and mix it well. Do not feed your horse tor mtich hay, as it is not only a waste of provender, bet wien he is put to work with an ovarloaded stomach it endangers his wind. If Ieft to puli hay out of the rack ai pleasure, a horse will eat and waste somp thi:ty pounds a day, whereas, by cutting up his hay anc mixing it with other feed, as above described, ten pourds is an ample abundance for twenty-fous 
hours. Horscs, wheis worked, shorld be fed three or four times a day with a mixture of hay, straw and grain, as above described. Give them their food in the manger, anc be careful that it is swee and clean. By following these rules, your horses will always be in gooà condition-will not have that swelled belly so peculiar to animals who ara allowed to fill their storachs with hay--ard will usually enjoy good hecith.

\section{RLLES FOI. PURCHASING A HORSE.}

When you are looking to purchase a horse, first examine the eyes weli. The best judges are sometimes deceived in the eyes, therefore you cannut be too careful. Clearness of the Eyes is a sure indication of their goodnoss; but this is nct all that should be attended to : the eyelids, eyebrows, and all the other parts, must also be considered; fo: many horses whose eyes appear clear and brilliant, go blind at seven or eight years old. Therefore be careful to observe whother the pats between the eyelids and the eyebrows are free from buncher. and whether the parts round the under eyelids be full, or swelled; for these are indications that tho eyes will not last. When the eyes aie remarkably flat, or sunk within their orbits, it is a bad sign; also when they look dead and lifeless. T'he iris, or rircle that surrounds the sight of the eye, should be distincr, and of a pale, variegated, cinnamon color, for this is always a sure sign of a good eye. and it adils beauty tc the appearance of the animai. 
In the next place, examine the Tecth, as you would not wish to purchase an old horse, nor a very young one for service.

The Feet should next be regarded; for a horse with bad feet is like a house with a weak founda. tion, and will do little service. 'The feet should bo smooth and tough, of a middle size, without wrinkles, and neither too hard and brittle, nor too soft; the Ileels should be firm, and not spongy and rotten; the Frogs horny and dry; the Soles somewhat hollow, like the inside of a dish or bowl. Such feet will never disappoint your expectations, and such only should be chosen.

Particular regard should be had to the Shoulders; they should not bo too much loaded, for a horse with heavy shoulders can never move well; and on the other hand, one that has very thin shoulders, and a narrow cliest, though he may move briskly so long as he is sound, yet he is generally weak, and easily lamed in the sloulders; a medium should therefore be chosen.

The Rody, or Curcass, should neither be too small nor too large. The Pack should be straight, or have only a moderate sinking below the Withers: for when the back of a horse is low, or higher behind than before, it is both very ugly and a sign of weakness. The back should also be a proper length. 'The Ribs should be large, the Flanks smooth and full, and the Hind-parts, or uppermost Huunche's not higher than the shoulders. When the horse trots before you, ohserve if his haunches cover his 
fore-knecs. A horse with a short hind-quarter does not look well.

The next thing to be regirded in a horse is his Wind, which may be easily judged of by the motion of his flanks. A broken-winded horse also pinches in his flanks, with a very slow motion, and drops them suddenly, which may be easily perceived. Many horses breathe thick that are not brokenwinded; indeed, any horse will in foggy weather, or if foul fed, without sufficient exercise; but if a horse has been in good keeping, and had proper exercise, and yet has these symptoms, there is some defect, either natural or accidental; such as a narrow chest, or some cold that has affected the lungs.

There are other particulars that should be observed in choosing a horse. If his Head be large and fleshy, and his Neck thick and gross, he will always go heavy on the hand, and therefore such should never be chosen. A horse that has his Hocks very wide, seldom moves well, and one that has them too near will chafe and cut his legs by crossing them. Fleshy-legged horses are generally subject to the Grease, and other infirmities of that kind, and therefore should not be chosen.

The Temper of a horse should be particularly attended to. Avoid a fearful horse, which you may know at first sight by his starting, crouching, or creeping, if you approach him. A hot and fretful horse is also to be avoided, but the buyer should be careful to distinguish between a hot, fretful horse, and one that is eager and craving. The former bo- 
gins to fret the moment he is out of the stable, and continues in that humor till he has quite fatigued himself; and the latter only endeavors to be foremost in the field, and is truly valuable; he has those qualities that resemble prudence and courage; the other those of intemperate heat and rashness.

A horse that goes with his fore feet low is very apt to stumble; and there are some that go so near the ground that they stumble most on even roads; and the dealers, to remedy to this, put heary shoes on their feet, for the heavier a horse's shoes are, the higher he will lift his feet. Care also should be taken that the horse does not cut one leg with the other. A horse that goes near the ground will cut the low side of the fetlock joint, but one that goes high cuts below the knee, which is called the speedy cut. A horse that lifts his feet high, generally trots fast, but is not the easiest for the rider. Some horses cut with the spurn of the foot, and some with the heel; but this you may soon perceive by their standing; for if a horse points the front of his foot inward, he cuts with the spurn, and if outward, with the heel.

'These few instructions may be of use in purchasing horses; but I advise every one to get some experimental knowledge of them before he trusts to his own judgment, for the dealers have so many arts to hide the defects of their horses, that the best judges are often deceived. 


\section{K N O W L S O N'S}

\section{COMPLETE FARRIER AND}

HOIR S D O T T I. 


\section{INDEX TO CONTENTS.}

Back Sinerrs, sprain in.........46 Bladder, disorders of............ 29

Blood Sparin..................51

Bone Spavin................... 50

Bots and Worms..............11

Broken Wind..................22

Bruises of the Withers..........58

Coffin Joint, sprain in..........46

Cold, remedy for............... 3

Colic, or Gripes................ 7

Colic, Flatulent or Windy...... 7

Colic, Bilious or Inflammatory... 9

Convulsions .....................16

Corb ......................... .52

Congh and Asthma............ 5

Crown Scab, the.............62

Cup-Bone, lameness in the........48

Farcy, or Farcin...............37

Zarcs, the Water ................41

Feet, hurts in the..............56

Fevers ........................17

Ferer, a Compound.............19

Fistula, or Bruises of the Withers 58

Founders ....................42

Girth-Galls, Plushes, \&c. ........59

Glanders, the.................54

Grease, the...................60

Gripes, the Dry................10

Gripes, or Colic............... 7

Hidebound, the..................35

How to Manage a Horse on a : Journey....

Hurts in the Feet..............56

Imposthumes .................54

Intestines, disorders of...........27

Jaundice, or Yellows............13

Journey, how to manage on a....62,
Kidneys and Bladder, disorders of 29

Knees, sprain in ...............47

Lameness in the Stifle..........47

Lameness in the Cup-Bone ......48

Mallenders and Sallenders.......52

Yange, the ........................

Joulten Grease.................32

Pasterns, sprain in.............47

Poll Evil ....................43

Plushes from Saddles............59

Remedy for a Cold ............. 3

Ring-Bone .................... 52

Sallenders .....................52

Scouring.....................27

Scratches....................61

Sparin, Bone.................50

Spavin, Blood or Bog...........51

Sprain in the Back.............44

Sprain in the Shoulder..........45

Sprain in the Coffin Joint........46

Sprain in the Back Sinews......46

Sprains in the Knees and Pasterns 47

Stag Evil.................... 16

Stifle, lameness in the..........47

Strangles, the.................52

Surfeit...............................

Swellings and Impostumes........54

Twitter-Bone ................57

Warbles, Girth-Galls, \&c. ........59

Water Farey, the...............41

Whirlbone, lameness in the......48

Windgalls .................... 60

Wind, a Broken.............. 22

Withers, bruises of.............58

Worms and Bots.................

Wounds ..........................55

Yellows, the.................13 


\title{
THE COMPLETE FARRIER,
}

\author{
or,

\section{HOR SE DOCTOR.}

\section{Remedy for a Cold.}

People not much accustomed to study the diseases of horses, look upon a cold as a trivial matter. But they should bear in mind that nearly the whole of the disorder's to which this noble animal is liable, derive their origin from a Cold. The causes of Colds are various, but the most usuai one is riding the horse until he is hot, and then suffering bim to stand still exposed to the cold air; removing him from a hot stable to a cold one : if the horse has been highfed, and clothed, the cold contracted in this manner often proves very violent; and this is the reason why horses often catch a serere cold on their first coming out of the dealer's hands : neglecting to rub him properly down, and to rub the sweat carefully off when he comes in from a journey; and I have known grievous disorders brought on by removing horses into a new stable before the walls and plastering were dry. Workmen are often in fault for not leaving airholes above; as when a horse comes into a new stable, and gathers heat, it will cause the walls and plastering to sweat very much, especially if there are no air-holes left. Many a horse has lost his eyes, and some their lives, by being put into new stables before they were dry.

Symptoms. - When a horse has caught a cold, a cough will follow, and he will be heavy and dull in proportion to the severity of the disease : his eyes will be watery; the kernels about his ears. and under his jaws, will swell, and a thin, mucous gleet will run from his nose. If the cold be

- riolent, the horse will be feverish; his flanks will heare, and he will refuse his food. The owners should be very careful to obserre these last symptoms, because when they appear, and are attended with a slimy mouth, cold ears and feet, moist eyes, and a great inward soreness, there is danger of a fever, and generally of a malignant kind. But when the horse coughs strongly, and snorts after it, eats scalded bran, and drinks warm water, moves briskly in his stall; dungs and 
stales freely, and without pain, his skin feels kindly, and his coat does not stare, there is no danger, nor any occasion for medicine. You sbould, howerer, bleed him, keep him warm, give him some feeds of scalded bran, and let him drink warm water.

THE Cure.-If the horse feels hot and refuses his meat, it will be necessary to bleed him plentifully, and to give the following drink:

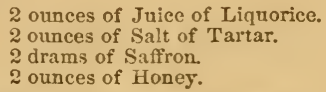

Cut the juice small, dissolve all together in hot water, and give it nearly cold. This drink may be repeated as occasion requires, but let twenty-four hours elapse first. Or give

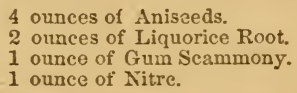

Boil these together in three pints of water for ten or twelre minutes; strain the liquor through a cloth; and add two unces of honey to it when you give it to the horse.

The following ball, commonly called The Cordial Ball, is one of the best yet found out for coughs or colds. Be careful to get your drugs good, for this ball is of great worth in many diseases : and few things will remore a cough or cold, or clear a horse's wind, sooner or better :

Take 4 ounces of Aniseeds Powder.

4 ounces of Fenugreek.

4 ounces of Liquorice Powder.

4 ounces of Elecampane Powder.

4 ounces of Flour of Brimstone.

6 ounces of Grains of Paradise, in fine powder.

4 ounces of Liquorice, cut small, and dissolved in White Wine.

1 ounce of Saftron, pounded small.

1 ounce of Oil of Aniseeds.

8 ouners of Olive Oil.

8 ounces of Honey

Bray them all well together till they come into paste, and if they should be too dry, add a little more olive oil and honey. The dose is abcut two ounces, and may be given three or four times a day, if needful. These balls, consisting of warm, opening ingredients, are of great use; and given in small quantities, about the size of a pullet's egg, will enconrage a tiree perspiration; but in case of a Ferer, they should be giren with the greatest caution.

It will be of great use to put scalding-hot bran into the manger, that the horse may hold his head over it, and receive 
the steam up his nostrils, which will cause a running from them, and relieve him very much. I have known asarabacen, dried and rubbed to powder, and blown up the nostrils. to cause a discharge; for when a horse has eaught a violent cold, he is often troubled with a pain in his head, which a good discharge at the nose is very likely to eure. For the same purpose the horse should be warmly clothed, especially about the head, neck, and throat, as it has a tendency to promote a rumning at the nostrils.

By this simple method, with proper care, hot mashes, and warn water, most colds may be cured; and as soon as the horse begins to feed heartily, and snorts after coughing, an hour's exercise every day will greatly hasten the eure. If the legs swell, and the horse be full of tlesh, rowels are necessary.

\section{A Cough, and Asthma.}

Among all diseases to which this noble creature is subject, none has given more perplexity to Farriers than a settled Cough ; incleed it too often defies all the attempts of art, and the horse frequently becomes Asthmatical, or Brokenroinded.

Cacses. - The canses are rarious. Sometimes it is owing to colds imperfectly cured; sometimes to pleurisies, ol malignant fevers, which have left a taint upon the lungs or other vessels ; sometimes to small eruptions in the glants, which cause the lungs to be much larger than they ought to be, and a quantity of phlegm, and mucilaginous juices, which stuff up the glands and branches of the windpipe ; and sometimes to fleshy substances engentered in the large blood ressels; for all these things hinder a free respiration, and excite a cough. It is of the utmost importance to distinguish one kind of cough from another, and this makes the disorder so hard to cure: for it can not be cured till the seat of the complaint be found out.

If the cough be of long standing, attended with a loss of appetite, wasting of flesh, and weakness, it denotes a Consumption; and that the lungs are full of knotty, hard substances, called tubercles. When a congh proceeds from phlegm, and mucilaginous matter, stuffing up the vessels of the lungs, the flanks have a sudden, quick motion : the horse breathes quick, but not with his nostrils distended like one that is broken-winded; his cough is sometimes moist, and sometimes dry and busky; before he conghs he wheezes. and sometimes throws out of his nose or mouth large pieces 
of white phlegm, especially after drinking, and this discharge generally gires rery great relief.

Ccrk:-If the horse be full of flesh, take from him a moderate quantity of blnod. The next day gire him scalded bran, and in the evening the following ball:

1 ounce of Powder of Aniseeds.

1 ounce of Liquorice Powder.

1 dram of Calomel, 8 drams to an ounce.

Work them into a ball with Barbadoes tar. Gire this ball the last thing at night, and be careful to keep the horse out of wet, and from cold water the next day. On the second morning give the following purge :

1 ounce of Barbadoes Aloes.

1 ounce of Castile Soan.

$1 / 2$ ounce of Powdered Ginger.

1 drain of Oil of Aniseeds.

Bray them together in a mortar, with a little syrup of buckthorn to make them into a ball, which is to be giren in the morning, and plenty of warm water, and walking exercise, till it be wronght off. It will not work the first day. In three dars after, give six ounces of the Cordial ball in a little warm ale, fasting. and to fast two hours after. Repeat the Calomel ball, phrsic, and Cordial ball, six alays after, in the same manner as before. Let the horse's bay be sweet, and his manger-meat scalded bran, with a spoonful of honey in each feed : let him hare walking exercise in the open air, but be careful of wet, and of cold water.

When this course has been pursued two or three times, give two or three ounces of the Cordial ball erery morning. The above method will remore most Coughs, but if it fail, try the following :

1 ounce of Gum Ammoniacum, in fine powder.

1/2 ounce of Gum Galbanum, in powder.

2 drams of Saffron, brayed.

2 drams of Assafœtida, in powder.

Work them up with honey, or Barbadoes tar. into one ball; roll it in liquorice powder, and give it fasting. and to fast two hours after. This ball must be giren erery morning, for six or seren times, before it can hare a fair trial. In the cure of this disease, the diet should be very moderate. the usual quantity of hay should be abridged. and sprinkled with water, and the usual allowance of grain and water divided into several portions; for with these regulations in diet the disease will soon be cured; and where it is incurable, the horse will be so far recovered as to be able to do a great deal of work. 
It may not be improper here to add that some young horses are subject to coughs when cutting their teeth. and their eyes are also affected from the same canse. In these cases always bleed, and if the cough be obstinate, repeat it, and give warm mashes, which are often suftieient alone to remove the complaint. When young horses have a cough that is eaused by worms, as is often the case, such medicines must be given as are proper to destroy those vermin. [See Worms.]

\section{The Colic, or Gripes.}

The Colic proceeds from various causes; therefore the method of cure varies; for otherwise the medicines intended to cure it may inerease it. and perhaps render it fatal. We shall, therefore, divide this disorder into three different species, and endeavor to give such plain directions for managing each, as can not fail to prove very beneficial. The three species are these :-1. The Flatulent, or Windy Colic ;

2. Bilions, or Inthammatory Colic;

3. The Dry Gripes.

\section{The Flatulent, or Windy.Colic.}

Srmptoms. The horse is rery restless, lying down and starting up again. He strikes his belly with his hind feet, stamps with his fore feet, and refuses his meat. When the pain is violent, he has convulsive twitches; his eyes are turned up. and his limbs stretehed out, as if dying; and his ears and feet alternately cold; he falls into profuse sweats, and then into cold damps; often tries to stale, and turns his bead frequently to his flanks; he then falls down, rolls about, and often turns on his back. This last symptom proceeds from a stoppage of urine, which generally attends this species of colic, and may be increased by a load of dung pressing on the neck of the bladder.

Causes.-This disease often proceeds from catching cold by drinking cold water when hot, and the perspirable matter is by that means thrown upon the bowels, which causes them to distend violently, and sometimes brings on an inflammation in the small intestines, when the body begius to swell, and the cure is despaired of.

CurE.-The first thing to be done is to empty the straight gut with a small hand dipped in oil. This frequently gives room for the wind. before confined in the bowels, to discharge itself; and, by taking off the weight that pressed upon the neck of the bladder, the suppression of urine is removed, 
upon which the horse immediately stales, and becomes much easier. If the horse be young, and full of blood, it will be proper to take a sufticient quantity of blood from the neck.

When these purgative operations have been performed, the following may be given, as it seldom fails to give relief:

4 ounces of 'Tincture of Senna, or Daffy's Elixir.

6 drams of Tineture of Opium.

1 dram of Oil of Juniper.

8 ounees of Juniper Berries, bruised.

Put one quart of boiling water on the juniper berries, let them stand a few minutes, strain it off, put all together, and give them to the horse.

If he does not find relief soon after taking this dose, both by staling and breaking wind, it is doubtful whether be will receive any benefit from it; so you must prepare the following clyster for him as soon as you can:

Take 4 ounces of Camomile Flowers.

2 ounces each of Aniseeds, Fennel and Coriander.

Boil them in one quart of water, and add 2 ounces of Castile Soap, cut small, while the water is hot, that the soap may dissolve. Give it blood warm. During the fit the horse may be walked abont, or trotted a little, but should by no means be harrassed, or driven about till he is jaded. If no better, give the following :
2 drams of Camphor.
1 dram of Pellitory of Spain.
2 ounces of Ginger Powder.
3 gills of Holland Gin.

If the horse sweat much at times, and then falls into cold sweats, give four ounces of mithridate, in three gills of Holland gin. and repeat the clyster. If the disorder continue three or four hours, give one ounce of tincture of opium, in three gills of Holland gin. When the horse begins to recover, he will lie quiet, without starting and trembling; and if he continues in this quiet state an hour, you may conclnde that the danger is over. Dress him down well, and give him a small quantity of warm water, if he will drink it : bed him down well, cover hin to keep him warm, and then leave him to get a little rest. You must consider that the disorder has left a little soreness on him, both within and without; therefore, make him a little gruel, with a pint of red wine in it; and if any skin be knocked off abeut his ejes, or his huckbones, rub it with the wash recommended for bruises.

Sometimes the Colic is received into the stomach, and does not act so violently, nor cause the horse's pains to toe so strong. You may best judge of this by his motions. He 
will draw his four fect together, lay himself down, stretch out his feet and head, throw his head back, and often put his nose to his chest; after standing a little, he will lie down again as before. When the colic is easier, he will lie for an hour or more together, with his feet stretched out and his head thrown back, or with his nose upon his ribs. This is cansed by bad feed, or bad water, or both: sometimes by drinking hard water when hot. or by a change from soft grit water to limestone or iron water, or by the break of a storm. I have had five or six horses under my care in this disorder in one day, at the break of a frost, by drinking ice or snow water. Sour grains, sour grass, dry meal, dust, bad hay, and many other thing cause this disorder. Give the following, which is almost a certain cure in two hours ·

\section{- 1 ounce of Spirits of Sweet Nitre. \\ 1 ounce of Spirits of Yitre \\ 1 ounce of Tineture of Opium. \\ 1 ounee of Sweet Oil.}

All to be given together in a gill of warm ale. Bed the horse well down, and leave him that he may get a little sleep, after which he will get up and feed. This is one of the best medicines that has yet been found out. It has saved hundreds of horses, and will save hundreds more if rightly applied.

\section{The Bilious or Inflammatory Colic.}

Sxмpтомs.-This kind of Colic. besides most of the synnp toms of the former, is attended with a fever, great heat, pant ing, and dryness of the mouth. The horse also generally parts with a little loose dung, and a little scalding-hot water; which, when it appears blackish, or reddish, indicates an ap. proaching mortification.

Take 3 ounces of Senn?.

1 ounce of Salt of Tartar. Infuse them in a quart of boiling water an hour-strain, and add

2 ounces of I,enitive Eleetuary.

4 ounces of Glauber's Salt. Mrix when hot.

If the disorder be not remored by the above medicine, but, on the contrary, the fever and inflammation continue to increase, attended with a discharge of flesh-colored matter, the event will probably be fatal; and the only medicino likely to prevent it, is a strong decoction of Jesuit's bark, a pint of which may be given every three hours, mixed with a gill of red port wine; or you may give one ounce of the powder of bark with the wine. Or, if these can not be got easily, give four ounces of tincture of rhubarb in three gills 
of red port wine. Also give a clyster erery two hours, marle of two new-laid eggs, well broken. and two ounces of molasses, in one quart of milk. Gire it warm.

If the horse recover, it will be proper to give him a gentle purge or two in a week after.

Take 1 ounce of Rhubarb, in Powder.

1/2 ounce of Jalap, do.

Work them up into a ball with syrup of buckthorn, and give it to the horse, with warm water to work it off.

\title{
The Dry Gripes.
}

Symptoms.-This disorder mostly proceeds from costiveness, and is discovered by the horse's frequent and fruitless attempts to dung, the blackness and hardness of the dung, the frequent motion of his tail, the high color of his urine, and his great uneasiness.

Curs.-The first thing to be done is to draw the dung out of the fundament, with a small hand, as far as you can reach, and then give the following:

\author{
4 ounces of Castor Oil. \\ 4 ounces of Tincture of Senna. \\ 1/2 ounce of Oil of Juniper.
}

Give them all together, and then the following clyster :

Boil in a quart of water a handful each of

Camomile Flowers and

Marshmallows. Strain off and add

2 ounces of Linseed Oil, or Pale Oil.

If the horse do not mend. repeat both the drink and the clyster. During this disorder the horse must not have any dry food; but boiled linseed and scalded bran, with warm water to drink. Gentle walking exercise is a great means to cause the physic to work; but be careful of cold.

From the account that I have giren of the different species of the Colic, the reader will be abundantly convinced how necessary it is to be acquainted with each, that he may be able to give proper medicines and to relieve the creature's excruciating pains. He should carefully avoid all hot, violent medicines, which always prove hurtful in every species of this disorder, and frequently fatal. Nor is it any wonder that horses treated in that manner should die, for such medicines stimulate the neck of the bladder, augment the heat of the blood, before much too great, and inflame the bowels, by which a mortification is brought on, and the horse is lost by the very means used for his recovery 
Sharp fits of the Gravel are sometimes taken for the Colic ; but should ihis happen, the drink recommended for the Colic will also be proper for the Gravel.

\section{Worms and Bots.}

Horses are subject to five sorts of worms, and perhaps to many more, but I shall only describe three, which are the most common. The worst sort to destroy are long, round worms, resembling earth-worms, but smaller at the tail; they have a seam all the length of their bodies, and are very hard: these are called Round Worms. The next are small worms, about the size of a sewing needle; they have reddish flat heads, having nine feet on each side, and are called Ascarides: these are also very troublesome to borses. The third sort are short, thick worms, called Bots : their seat is mostly at the stomach, but when horses get any food that they are fond of, they fill themselves so full, that they lose their hold, and come along with the dung to the fundament, and there catch hold and stick to the end gut, partly out of the horse ; this happens mostly in Spring, when they get the juice of fresh grass.

It is well known that horses which have many worms can never thrive, or earry much flesh. If the breeding of these vermin were prevented, it would add much to the strength of the horse ; and it might be done by giving him a decoction of bitter herbs, such as wormwool, in Spring. It may be boiled, or steeped in hot water, and given two or three times a week. Or a decoction of wormwood, buck-bean, gentian root, and camomile flowers, of each a large handfiul, boiled in a sufficient quantity of water, and given as above, will answer the end.

Symproms. - The symptoms which indicate worms are various, as the animals are different, and seated in different parts of the body. When the Bots are seated in the straight gut, they are never dangerous, but are often thrust out with the dung. They generally come in the months of May and June, and scarcely ever continue in a horse above a fortnight. But when they breed in the stomach, they often cause convulsions, and even death. The Bots that breed in the stomach are about the size of a large maggot, composed of circular rings, and have little, sharp. prickly feet along the sides of their bellies, by means of which they fasten themselres to the part from whence they derive their nourishment, to prevent their being loosed from such adhesion before they come to maturity; and as they drain the coats of the stomach like 
leeches, it is no wonder that they often throw the horse into convulsions. which terminate in death. unless the cause be remored. The riolent agonies of the creature are the only indications of their existence. The other kinds of worms are mole troublesome than dangerous, and are discovered by the following signs: There is a white fur on the end of the straight gut; the horse is lean and jaded; his coat is rough and staring; and if you rub your hand backward on the hair, a white seurf will rise, as if he had been surfeited; and though he eats with a remarkable appetite. he does not thrive. He often strikes his hind feet against his belly, and is sometimes griped, but without the riolent pains that attend the colic, or stranguary ; for he never rolls or tumbles, but is uneasy, often laying hinself down quietly on his belly for a little while, and then rising and beginning to feerl. But the surest symptom is when the horse roids the worms with his dung.

The way these creatures get into the stomach is curious. While the horse is feeding, the bot-fly lights on his side in a place convenient to the animal's mouth. He then stings the horse and flies away. The horse naturally turns his head and throws his mouth to the place which has been stung-the eggs adhere to his lips, and in this way are taken into the stomach, where they hateh into worms, which instantly fasten themselres to the coats of the stomach. Keeping a horse well curried and brushed, and keeping him in stable during the fly-bot season, will often prevent the disease.

Ccre.-Many medicines have been given to destroy these rermin. without knowledge or judgment, and eren contrary to common reason. Some give coarse sugar for that purpose, but, in my opinion it will rather increase than destroy them; although a few will fill themselves so full as to lose their hold, and come away with the dung.

Take 1 ounce of Socotrine Aloes.

1 dram of Calomel, 8 drams to an ounce.

1 dram of Oil of Aniseeds.

2 drams of Powdered Finger.

$1 / 2$ ounce of Syrup of Buckthorn.

Beat all up together in a mortar till the Aloes are well broken. and the whole is brought into a paste; which give in the morning, fasting, and to fast one bour after ; also give warm water, and walking exercise, till wrought off. It will not work the first day. Be careful that the horse be open in bis borly before you give the ball. In grass time you will bave nothing more to do than to give it, and to put the borse 
where he can get water. This dose is for a pretty strong horse, so you must add or diminish according to size. This dose must be repeated as need requires, but not within seven days. It will destroy most kind of worms; but the bard round worms require different treatment, as they are the worst of any to get rid of. To destroy them give the , following :

1 dram of Calomel, 8 drams to an ounce.

6 drams of Jalap.

6 drains of Rhubarb, in powder.

Wrought up into a paste with conserve, or honey; and two days after give the following:

1 dram of Calomel, 8 drams to an ounce.

1 ounce of dried Foxglove Leaves, powdered.

$1 / 2$ ounce of Worm Seed, powdered.

1 ounce of Jalap, in powder.

To be given in three gills of malt liquor from the mashtub. If the above be given every week for three weeks together, you may be sure that most of the vermin will be expelled. If the medicines be given in the bouse, let the food be light and opening, and warm water for two days, with walking exercise.

I advise all who have horses troubled with worms, to give savin, dried and powdered, beforo they give the worm physic. If one ounce a day be given for a week before, in a mash of bran, it will be much better. The above ball is good for many disorders besides worms.

\section{The Yellows, or Jaundice.}

This disorder is very common in horses, and sometimes it is either unknown, or overlooked, till it gets much worse to cure. A young horse is easily cured. but an old one is bad to eure. Some people may say, Horo can a horse have the Jaundice, wchen he has no gall-bladder? I auswer, Though he has no gall-bladder in sight, he has a large vessel in the liver rchich answers the same end. IVe may here observe, the handiwork of God in placing a horse's gall-bladder differently from those of other animals, when we consider that the. horse is the swiftest and most laborious creature in the world; so that if the gall-blarlder had been placed on the liver, it would always have been exposed to injuries.

Srmptoms.-The white of the eyes is jellow, also the inside of the mouth, the tongue, and the bars in the mouth, are of a dusky yellow; the horse is dull, and refuses all kinds of food; a slow fever is perceived, which increases with the 
Jellowness; the dung is often hard and dry, and of a pale yellow color ; the urine is commonly of a dark, dirty brown, and when it has settled, sometimes looks like blood: tho horse stales with pain and difficulty; and, if the disorder is not checked, becomes in a short time unable to stir about. When this disease gets strong hold of a horse before proper medicines are applied, it is often fatal, or it brings on some other disorder as bad, or worse than itself.

Cure.-Bleed plentifully, and as this disease is always attended by a costive habit of body, it will be proper to give a clyster or two before you give the physic. A clyster may be made of one ounce of camomile flowers, boiled in a quart of water with two ounces of Castile soap. 'Then give the following ball :

4 drams of Indian Rhubarb.

2 drams of Saffron.

6 drains of Socotrine Aloes.

1 ounce of Castile Soap.

To be brayed in a mortar with a little syrup of buckthorn, and made into two balls; one to be given the last thing at night, and the other the first thing in the morning; and give plenty of warm water to work them off. If the disease is obstinate and will not yield to the above, give the following ball :
1 dram of Calomel, 8 drams to an sunce.
1 ounce of Barbadoes Aloes.
1 ounce of Venice Soap.
1 ounce of Turmeric.
1 dram of Oil of Juniper.

All to be brayed in a mortar with a little syrup of buckthorn, and made into two balls; one to be given at night, and the other in the morning, with plenty of warm water. and walking exercise till wrought off.

If the horse is better after the first medicine, repeat it, for it is much safer than the last; but if not, the last may be given, and repeated as need requires; but be careful not to give it in less than six days distance.

If, after giving one dose of the last ball, you give the following powders every day in celantine tea. if it can be got, or in warm ale, you will find them very useful in removing the complaint.

2 ounces of Salts of Tartar.

1 nunce of Ethiop's Mineral.

2 ounces of Turmeric.

These powders are proper to be given after either of the former doses. 


\section{The Staggers.}

This disease is caused by the liver making blood so fast that the cavity of the heart is overloaded and the blood flies uy the neck vein till the head is overloaded too; and if relief can not be obtained, the horse soon dies.

Sruptous. - The most common are, drowsiness, watery and somewhat full and inflamed eyes, a disposition to reel, feebleness, a bad appetite, the head generally hanging down, or resting on the manger. There is little or no fever, and the dung and urine are very little altered. The horse soon begins to reel, and falls down, and sometimes is so outrageous as to bite every thing in his way.

Cure.-In the first place, bleed him well as soon as you possibly can, by striking the reins in sereral places at once, and taking away four or five quarts at one time; and, in order to raise up his head and shoulders, support them with plenty of straw. If he survive the first fit, cut several rowels, give him clysters at night and morning. made of barley-water and a little sweet oil and salt; and blow up his nostrils a little Cayenne pepper, or white hellebore. Also give him

4 drams of Bark.

16 grains of Turbeth Mineral.

$1 / 2$ ounce of Camphor.

Give it in a little warm ale. When ale cannot be conveniently had, any other beverage to disguise the taste will answer. If the horse be ontrageous, give him

1 ounce of Tincture of Opium.

1 gill of Syrup of Poppies.

1 ounce of Tincture Guaiacum.

Be careful not to let him knock his head, for it will increase the disorder. If he gets throngh the first fit, give him two ounces of crocus metalorum every day, to thin his blood for fear of a relapse. It will be proper to give him the following ball once a month for some time after:

1 ounce of Rhubarb, in powder.

$1 / 2$ ounce of Jalap.

1 dram of Calomel, 8 drams to the ounce.

To be made into a ball with syrup of buckthorn. This ball will be of great use in thinning the blood, and preventing a return of the disorder ; for when a horse has had one fit of it, he is very likely to have another, if care be not taken to prevent it. 


\section{Convulsions, or the Stag Evil.}

Of all disorders to which horses are subject, this is the worst, and is scarcely discoverable till the horse falls down raging mad. It seizes him all at once, without any previoug warning. He raises bis head, with his nose toward the rack, pricks up his ears, and cocks his tail. In this posture he continues, and those who do not understand the disorder never suppose that he ails any thing of consequence. But other symptoms soon convince them of their mistake; for his neck grows stitf, cramped, and almost immovable; his jaws are locked, and every tendon in his body becomes stiff. If he can get his mouth open he will bite any thing that comes in his way; and if he lives a few days in this condition, several knots will arise on the tendinous parts of it. Every muscle is so much cramped and extended. that the horse looks as if he were fastened to the place, with his legs stiff, wide, and staggering, and the skin drawn so tight over every part of his body, that it is almost impossible for him to move ; and if you attempt to make him walk, he will be ready to fall at every step, unless he be well supported. At the same time his eyes are so fixed by the contraction of the muscles as to give him a dead look. He snorts and sneezes often, pants continually, and his shortness of breath increases till the distemper takes a favorable turn, or the horse falls down and dies.

Cure.-In the first place, bleed plentifully, unless the horse be old and low in flesh, or taken from some hard duty, and then you must not take so much blood. After bleeding give the following ball, if you can get it in, but the horse is very often jaw-locked till nothing can be got in but by clysterpipe put between his fore and axle teeth.

$1 / 2$ ounce of Assof œtida.

$1 / 2$ ounce of Gum Guaiacum.

1/2 ounce of Gum Camphor.

Make them up into a ball with honey, and give one of these balls every twelve hours, for two days, if you can get them in ; and if not, dissolve them in a little hot beer, and give them with the clyster-pipe. Be careful to powder the Gums. Then make an ointment or lotion of the following :

1 ounce of Oil of Spike.

1 ounce of Oil of Amber.

1 ounce of Oil of Bricks.

1 ounce of Spirits of Sal Ammoniac.

Shake them well together, and rub the jaws just below the 
ears. where they lock in the upper chap ; also rub the small of the back well, where the cross bones join the back bone.

In this, as in most other disorders, the body should be kept gentiy open with laxative purges and emollient clysters. When the jaws are so locked that you can not get any thing in, do not open them by force, for that would increase the disorder instead of reliering it.

Sheep skins, newly taken off, and laid with the flesh side to the horse, will sweat him greatly, and by that means draw a quantity of water from the blood: indeed, there are few things that will relieve a locked jaw more: but if they be laid on the loins, they must not lie above three hours at a time before they are turned with the wool side to the horse. You may keep the skins on twenty-four hours if you change sides every two or three hours.

If the horse can not take either food or water in at his mouth, he must be supported by elysters, made of barleywater and milk, and giren both at the mouth and the fundament. I once supported a large wagon-horse in this manner for twelve days, and he recovered.

Convulsions are caused by different things, but often by bots in the stomach; for these destructive rermin suck up the juices that should feed the blood, and bring it into a thin, bad state; indeed they are sure to destroy the horse by one means or other when there are a great number of them in the stomach.

When youl suspect that these rermin are the eause of the disorder, give the ball recommended to destroy bots. If the horse get better the first time, be s!re to guard against a relapse, for he will not be apt to get better a second time.

Tapping under the jaws, and at the breast, is sometimes of great service in this disorder, but I am of opinion that sweating with sheep skins will relieve much sooner. If the stiffness of the jaws continues after the convulsions bave ceased, the following medicine should be given :

\footnotetext{
$1 / 2$ ounce of Matthews' Pill.

$1 / 2$ ounce of Assafcetida.
}

Make them into a ball, and gire it twice, (one day between the doses,) and it will give relief.

\section{Fevers.}

Horses are subject to few disorders which are not attended with more or less fever.

Cadses.-Ferers are often brought on by sudden heats and colds; by going out of warm stables into cold ones; by be- 
ing clothed, and then haring the clothes stript off; and hy being turned out to grass; for many people turn their horses out to grass in the morning. and let them lay out, which is quite wrong: for when they are turned out to grass, to be there night and day, it is best to turn them ont at night, for then they will graze all night; but if you turn them out in the moruing, they will fill themselves in the day-time, an 1 lie still all night, which is the way to catch cold. Most fevers are brought on by colds, therefore be careful to keep your horses as much as possible from catching cold.

Sxwptoms.-The horse is remarkably restless, ranging from one end of his rack to the other: his flanks work, his eyes appear red and inflamed, his tongue is parched, and his breath hot and of a strong smell. He often smells at the ground, he loses his appetite, and though he will take hay into his mouth, he does not chew it; his whole body is hotter than usual, but not parched : he dungs often. but little at a time. and it is generally hard, and in small pieces; his urine is high-colored, and he generally stales with pain and difficulty; he is always craving for water, but drinks very little at a time; and his pulse is much quicker than usual.

Curk.-Whenever a ferer talies place, the first part of a cure is bleeding, and if the horse be strong and in good condition, the quantity should be two or three quarts. When this has been done, give him a pint at a time of the following infusion, three or four times a day:

4 ounces of Juice of Liquorice.
4 ounces of Iiquorice Root.
2 ounces of Salt Petre.
4 ounces of Salt of Tartar.
8 ounces of Good Raisins.
2 ounces of Aniseeds.
2 drams of Saffron.

Boil all these together in six quarts of water. for ten minntes; let it stand till cold, and then strain it off. It is one of the best medicines for colds, conghs, hoarseness, or fevers. in either horse or man; and if it were more known. and more used, it would give greater relief in violent colds than any thing yet found out. It is kind in its operations. opening to the lungs, works gently by stool and urine, is free in its passage, and opening in its nature.

The horse should scarcely eat any thing but mashes made $o^{f}$ linseed and bran, and giren in small quantities. If he - $\rightarrow$ fuses them, let him have dry bran sprinkled with water, ard put a little hay into his rack, as a small quantity of it $\therefore$ i! not hurt him, and a horse will often eat hay when ke 
will not eat any thing else. His water should be rather warm, and given often, but in small quantities; and his clothing moderate, too much heat being pernicious in a fever. If he refuse his meat, do not let it lie before him, but take it away, and clean his rack and manger. If he be able to go about, a little walking exercise in the open air will be very proper, but you must be careful not to get hin wet.

This method, with good nursing, will often be sufficient to restore the horse to health; but if he refuse his meat, more blood should be taken from him, and the drink continued; and if his dung be hard and knotty, a clyster should be given.

Take Marshmallows and

Camomile Flowers, a handful each.

Boil one-third away in three quarts water-strain, and add 4 ounces of Venice Treacle.

1 pint of Pale Rape Oil.

The abore will make three clysters, to be given at four hours distance. If lis pulse continue high and quick, give the following :

\footnotetext{
2 ounees of Nitre.

2 ounces of Cream of Tartar.

4 ounces of Glauber's Salt.

2 ounces of Lenitive Electuary.
}

Dissolve them in hot water, gire one-half, and the other half the day following. If the horse be very open in his body, you need not give the above; but if dry, be sure to give it him. If he be very open, give him four drums of bark in a gill of red port. By pursuing this method, the horse will begin to recover, and will relish his hay, though his flanks will continue to heave for a fortnight. Nothing more will be requisite to complete the cure than walking him abroad in the air, and giving him plenty of clean litter to rest on in the stable.

There is another and much worse kind of fever to which horses are often subject, and which often proves fatal if not properly treated, viz. :

\section{A Compound Fever.}

Srmptoms. - The symptoms of this disease are-a slow ferer, with great depression; and sometimes inward heat and outward cold, and at other times heat all over. but not excessive. The horse's eyes are moist and languid; his mouth is continually moist, so that he is not desirous of drinking, and when he does drink, a rery little satisfies him; he eats very little, and moves his joints in a loose, fechle manner. 
grating his teeth rery disagreeably; his body is generally open. his dung soft and moist, and he stales irregularly, , sometimes making little water, and at others a large quantity, which-is of a pale culor, and has very little sediment.

Cunk.-In the first place, take from the horse a moderate quantity of blood. Let it not exceed three pints, but repeat the operation according to its strength, if there be any tendency to inflammation; after this the nitre drink already described may be given, with the following addition:

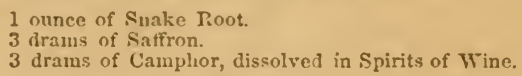

The horse's diet should be scalded bran; and linseerl, boiled, and wronght up with bran. Also give him the best hay by a handful at a time. It is often necessary to feed him by the hand, for sometimes he is not able to lift his beal to the rack.

In this disease, drinking is absolutely necessary to thin the bloot ; and therefore if the horse refuses warm water. he should be indulged with such only as had the cold taken otf. This niay be done with a hot iron, or by letting it stand in the pail in a warm stable; and this will be better than foreing warm water on the horse's stomach. If this method does not prove sufficient, but the ferer shall continue to increase, the following ball should be given immediately, as the danger augments every hour.

$$
\begin{aligned}
& 1 \text { ounce of Camphor. } \\
& 1 / 2 \text { vunce of Fin Myrrh. } \\
& 1 \text { ounce of Sintilis. } \\
& 2 \text { drams of C'utstor. }
\end{aligned}
$$

Make them up into two balls, and give one at night, and the other in the morning. If no better in a short time, give the following infusion :

$$
\begin{aligned}
& 1 \text { ounce of Snakr Ront. } \\
& 2 \text { ounce's of Fentian Ront. } \\
& 2 \text { ounces of Lemon Peel. } \\
& 2 \text { drams of Saffron. }
\end{aligned}
$$

Boil these well together in three quarts of water, and give a pint once a day. If the abore ball fails of success, give toe following:

\footnotetext{
1 ounce of Camphor, dissolved in Spirits of Wine.

1 ounce of Sal A numoniac.

1 pint of good Vinegar.
}

Put them all together, and stir them abont till the fume subsides. This is for two doses to be taken at twelve hours' distance, diluted with water. There is not perbaps a more 
powerful and effectual medicine lnown than camphor in all kinds of putrid fevers. it being active, attenuating, and particularly ealculated to promote urine and perspiration, the two prineipal outlets by which relief is to be obtained; and 'if this medicine were more often given than it is, it would be a greater credit to the farrier, and give greater relief to the horse.

If the horse be costive, clysters, or an opening drink, should be given; and should he purge mollerately, be careful not to suppress it; but if it eontinue so long as to enfeeble the horse, give him a little red port wine and bark. Also observe to let the animal drink plentifully, for that will greatly promote the operation of the above named medicines, as both the disorder and the medicines will eause a thirst. If the horse ean bear walking about, a little open air will be proper, but be careful to keep him well covered. Particular attention should also be paid to his staling, which if it flow in too great quantities, must be repressed by proper astringents, and by giving him lime-water; and, on the other hand, if he stale so littlo as to occasion a fullness or swelling in his body and legs, give the following drink :

\section{1 ounce of Nitre. \\ 2 ounces of Castile Soap. \\ 1 ounce of Venice 'Turpentine. \\ 2 drams of Oil of Juniper}

Make them into a ball with liquorice powder, and give them at twice twenty-four hours distance. These balls may be given as occasions may require, and are very proper to convey off the greasy, slimy matter from the passage of the urine, and to settle swelled legs.

These are the best methods of management, and will gen' erally prove successful; but sometimes art will fail, and the horse will discharge a greenish or a reddish gleet from his nostrils, and sneeze very frequently; he will continue to lose his flesh, become hide-bound, refuse his meat, swell about his joints, and his eyes will appear fixed and dead ; a purging also ensues, and a dark-colored, fuetid matter is discharged. When these symptoms appear, the case may be considered desperate, and all attempts to save the horse will be fruitless.

In this disorder you must take care not to let the borse eat too much, for his diet should be light, and in small quantities at once, and increased gradually as he nua gain strength. When his skin feels kind, his ears and feet continue moderately warm, his eyes look lively, his nose remains clean and dry, his appetite mends, he lies down with 
ease, and dungs and stales well, you may conclude that the danger is nearly over, and that nothing more is needful but care to complete the cure. On the contrary, by orerfeeding, you will run the risk of bringing on a bad surfeit, and the horse may be, according to the old saying,-liilled with keeping.

Sometimes the fever returns; so that every one who has a horse in a fever should be careful of cold for some time after, as his blood is left in a thin, bad state. His legs will probably be subject to swell; and if the swelling leave a dimple when you press your finger upon it, it is a sign of a dropsy; in which case it will be advisable to put two rowels on each side of his belly, and to give him half an ounce of the best yellow bark every day for some time. At other times a ferer leaves a running at his nose, of a thin, yellow, glueish matter, and small swellings below his ears and chaps. When you find these symptoms, give owe ounce of crocus metalorum every day in a mash of bran, and rub the swellings with mercurial ointment.

Care should be taken to keep the head and throat warmer than common, as the kernels about the latter are swelled; and also to promote a free perspiration, and to increase the running at the nose, which has the same effect in horses as spitting has in the human species; but never syringe the nose, as is often done, to promote the discharge, for it has an effect quite contrary, and lessens the quantity of matter instead of increasing it; and checking the discharge of matter at the nostrils otten causes swellings at the glands, and other bad consequences. Let me once for all remind you that all such discharges are critical, and thrown by Nature to free herself from the load that oppresses her, and consequently should by all means be promoted.

\section{A Broken Wind.}

This disorder may sometimes be prevented, but can not be cured; and it has hitherto been as little understood as any to which a horse is subject. People have had rarious opinions respecting its cause, and why some horses are more subject to it than others; but of all the opinions hitherto delivered, that of Mr. Gibson seems the best founded. He thinks that it is frequently owing to the hasty or injudicious feerling of young horses for sale; by which means the srowth of the lungs is rapidly increased, and all the contents of the chest so much enlarged, that in a few years the cavity of the chest is not sufficient to contain them when 
they are expanded "D perform their proper functions. Nor is this opinion foun lerl upon bare conjecture, for horses that have died broken-winded have been opened, and the lungs and other parts fomin too large for the chest. Kut although hasty feeding is often the cause of this disorder, yet it is not always, for a narrow chest may cause it. It has been ohserved that horses rising eight years old are most subject to it. The reason of this is, because a horse arrives at his full strength and maturioy at that age. At six he generally finishes his growth in height; then he lets down his belly, and spreads, and all his jarts gain their full size; so that the pressure on the lungs and the midriff is now increased.

Also, when the horse catches cold and gets a dry cough, the lungs are much lar time riding sharply is enough to force the lungs so hard against the midriff as to force a passage through it.*

A few year's back some people pretended to cure the complaint by boring; bat none were ever cured by it yet, nor ever will be. They made a hole above the fundament, to let out the wind that was forced through the midriff into the bowels; and this caused the horse to be continually discharging wind out of the place; so that the pretended cure was worse than the disease.

Dissections of horses that have died broken winded, have sufficiently proved the truth of the above observations; and that not only the lungs, together with the heart and its bag. were preternaturally large, but also the membrane which divides the chest; and that the midriff was remarkably thin. In some horses the disproportion has been so great that the beart and lungs have been almost twice their natural size, yet perfectly sound: and without inv ulceration whatever, or the least defect in the windpipe or in its glands.

From these observations it abundantly appears, that the enormous size of the lungs, and other contents of the chest, by hindering the free action of the midriff, is the prineipal cause of this disorder; and as the lungs are found much more fleshy than usual, they must consequently have lost a great part of their spring and tone.

Therefore, as this disorder is caused by the largeness of tlie lungs, we may conclucle that it is one of those diseases which can not be cured by art; and that the boastings of those who pretend to cure it are built on a sandy foundation. They may indeed relieve the complaint, but will never cure

* The Midriff, or Diaphragm, is that which is commonly called the Skirts, and separates the Chest (where the lungs lie) from the Bowels. 
it, for an absolute cure is not in the power of any human being. All that I can do is to lay down some rules which have a great tendency to prevent this disorder. if pursued in time; and some remedies that will aftorl relief when it has taken place and render the horse eapable of performing good survice, notwithstanling his misfortune.

Srmptoms.-The first symptoms of a Broken Wind is an obstinate dry cough, which is neither attended with sickness nor loss of appetite; but on the contrary, with a disposition to foul feeding, eating the litter, and drinking large quantities of water.

Prevextios:- When a horse is troubled with an obstinate dry cough, and eats his litter. it will be necessary to bleed him, and to give him the mercurial physic already prescribed, repeating it two or three times. Afterwards give the following balls for some time, which have been found of great service :

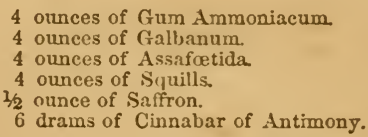

Make the whole up into balls with honey and a little liquorice powder, and give one about the size of a pullet's egg every other morning. This is a very good ball for a dry cough.

But it is not enough to give proper medicines; the horse's diet should also be earefully attended to at the same time, if we would hope for success. In order to this, the horse should eat very sparingly of hay. which, as well as his grain, should be wetted with chamber-ley, which is much better than water. Chamber-ley is best for this purpose, because of the volatile salts which it contains, as they aro a means of removing the thirst. For the same reason, garlic is rery efficacious in this disorder. Two or three clores being given in each feed; or three ounces bruised, and boiled in a quart of milk and water, and giren erery morning for a fortnight, has been found very serviceable. So easy a remedy should never be neglected; for, by warming and stimulating the solids, and at the same time dissolving the tenacious juices which choke up the ressels of the lungs, it greatly relieves this complaint. Morlerate exercise should never be omitted; and althongh broken-winded horses are not able to endure much labor the first summer, yet many hare been found less oppressed the secoud, and scarcely perceptibly 
affected the third, being then able to perform a long journey, and to endure great fatigue. A horse kept constantly in the field, when not in work, will be able to do good service for many years.

It may not be improper to obserre that those who hope to cure a broken-winded horse, or even one that is troubled with an obstinate cough, by putting him to grass, will find themselves wretchedly mistaken; for on being taken into the stable and fed with dry meat, he will be much worse than before; and some that,hud only a dry cough when they were put to grass, have returned broken winded. Therefore, always remember that if you can not keep a horse of this description constantly abroad, it is best not to put him to grass at all, as, instead of curing, it will tend to augment the disorder.

In short, the grand secret of managing horses of this kind, consists in having particular regard to their diet and exercise. A moderate quantity of hay or grain, and water, should be given at a time, and the former constantly moistened, to provent their wanting too much of the latter. T'hey should have moderate exercise, but never any that is violent. By this method, and giving the following ball once every fortnight or three weeks, the horse will be able to do good service for many years :

6 drams of Socotrine Aloes.

2 drams of Myrrh.

2 drams of Galbanum.

2 drams of Ammoniacum.

2 ounces of Bayberries, in porvder.

Make the whole into a ball with a little oil of amber, and a sufficient quantity of syrup of buckthorn. This ball operates so gently that there is no need for confinement, except a little the day following that on which it is given. The horse must have warm mashes and warm water, and the utmost care must be taken to prevent his catching cold.

\section{A Consumption.}

Srmptous.-A Consumption is a want of nowrishment, and a waste of flesh. The horse's eyes look dull, his ear's and feet are commonly hot, he coughs violently by fits, sneezes often, and groans at the same time; he gleets at the nose, and sometimes throws a yellowish matter, rather curdled, from his nose ; his flanks have a quick motion, and he has little appetite to hay, though he will eat grain, but be grows hot after it.

Causes.-Damp stables are most likely to bring on this 
disorder, though it may be brought on by many other things. In my time I hare known many horkes suffer much by dump stables. I knew a gentleman who had two valuable horses, and he built a brick stable for them, without any air-holes above their heads. He put the horses in as soon as the stable appeared dry, and their heat soon caused the walls of the place to sweat, anil to run down with water, by which means both the horses were thrown into a Consumption and died. I mention this to caution otber's.

Cure.-The first. and indeed one of the principal things to be done, is to bleed in small quantities. A pint, or at most a pint and a half, is sufficient at once, and the operation is to be repeated whenerer the breath is more than commonly oppressed. We are assured, by dissection, that in a Consumption both the glands of the lings and the mesentery are swelled, and often indurated. The only medicines that can be depended upon, are mercurial purges and ponderous alteratives. I have already given you examples of the former, and the following is a formula of the latter. Mix

\section{4 ounces of Crocus Metalorum. \\ 1 ounce of Calomel pp. \\ 1 pound of Gum Guaiacum, fincly powdered.}

Give about an ounce erery day in a massh of bran and linseed. Iceland liverwort, a bandful boiled in a gallon of water, is much better to make mashes up with than water; for it is a great helper of the blood. Lut it is to bo obserred that nothing will answer so good an end as Spring grass; so that if the horse be afflicted with this disease in Spring time, turn him out to grass as soon as jou can; and if the nights be cold, turn him out in the day-time, and take him in at nights. Salt marshes are the most proper places, when they can be met with. When a horse has had this disorder, he can never more bear cold and hard service as before.

\section{A Scouring, and Other Disorders of the Intestines.}

You should consider well what the Scouring proceeds from, whether it is cansed by foul feeding, bad water, hard exercise, sudden heat or cold, an overflowing of bile, or a veakness of the intestines.

If it is brought on by foul feeding, or bad water. it should not be stopped, but rather be promoted; for it should be remembered that Nature by this means throws off the seeds of disease, and evaeuates the morbid matter which would otherwise be retained to the great disadvantage, and per- 
baps to the destruction, of the animal. The great difficulty therefore consists in knowing when these discharges are critical and salutary, and when detrinental and noxions; for the former must not be checked, but the aid of medicine must be called in to put a stop to the latter.

For instance, - if a healthy horse, upon taking cold, or after hard riding, over feeding, or at the beginning of a slight fever, have a moderate purging, you must be careful not to stop it. but on the contrary to promote it, by an open diet, and plenty of warm gruel. But if this purging continue a long time, with smart gripings, and the inner skin of the bowels come away with the dung, and the horse lose both his flesh and his appetite at the same time, recourse must immediately be had to proper medicines; among which the following are very eflectual. I do not wish any one to give medicines upon merely hearing the names of the drugs, but to know first in what manner the drugs will operate.

\section{Take 1 ounce of Rhubarb, in powder. \\ 2 drams of Myrrh, do. \\ 2 drams of Saffron.}

Give altogether in warm ale, and warm water for two days after. This dose will not only work gently, but will be of great service to the horse, as it will bring away the slime which lodges in the small intestines, and correct the bile of the stomach, which is the cause of this disorder. When the disorder continues, and the horse:s flesh keeps wasting away, recourse must be had to astringents. Tormentil Root dried, and pounded in a mortar, and put through a seive, is one of the best astringents jet found out, though rery little known. The dose is from an ounce to an ounce and a half. I believe that this valuable root has done more good in my time, in stopping looseness and bowel complaints, than any thing else. When the purging is attended with fever, a different method of practice is necessary.

\section{Take $1 / 2$ ounce of Rhubarb, in powder. \\ 1 ounce of Lenitive Electuary. \\ $1 / 2$ ounce of Camphor. \\ 1 ounce of Powdered Ginger.}

To be given in a pint of old ale. This is a very proper medicine when the horse is troubled with a fever; but if he have no fever upon him, give the following :

1 ounce of Tormentil Root, in powder.

1/2 ounce of Japan Earth, do.

Give these in red wine, or if that be thought too expensive, in oak bark tea. Japan earth is a great healer of the bow- 
els. Repeat this last medicine three or four times to allow it a fair trial ; giving the horse at the same time but little exercise, for he can not then bear much. Should this medi. cine fail, and the disorder increase instearl of decreasing, which may be known by his flanks and belly being full and distended, and his appearing to suffer strong griping pains, give the following clyster :

1/2 ounce of Isinglass, dissolved in a quart of warm milk.

2 ounces of Mithridate.

Sometimes the flux is so riolent as not to be overcome by the preceding medicine. when recourse must be had to the following. Boil a handful of oak bark in a quart of water, strain it off, and add

2 ounces of Tormentil Root, in powder.

2 ounces of Bole.

Give them all together. This should be repeated once a day, for two or three days.

The practitioner should carefully attend to the symptoms that accompany this disorder; for if the discharge be attended with any acrid mueus, or slime, the griping pains being very severe, there is then a sure indication that the common lining of the bowels is wasted away; and then it will be necessary frequently to inject the following clyster, warm, in order to prevent the fatal consequences which will otherwise soon ensue :

4 ounces of Starch, dissolved in a quart of water.

Half a pint of Sweet Oil.

Yolks of three Eggs, well broken.

A little Loaf Sugar.

This will do for twice, at four hours' distance.

In treating this disease, be exceedingly careful to follow my directions, and to get good drugs, for your success will depend upon this, and a cautious watching of the symptoms.

It is also necessary to observe that some horses, from hav. ing weak stomachs and bowels, throw out their aliment un. digested, and their dung is habitually soft, and of a pale color; they also feed sparingly, and are always low in flesh. This complaint. which often proves fatal at last, may be removed by the following medicines:

\footnotetext{
6 drams of Socntorine Aloes.

3 drams of Rhubarb, in powder.

1 dram of Myrrh.

1 dram of Safiron.
}

Make all up into a ball with syrup of ginger. After the above stomachic purge shall have been given two or threo 
times, a pint of the following infusion should be given every morning :

Take 2 ounces of Orris Root,

A handful each of

Gentian,

Columbia Root,

Winter Bark, Aniceeds,

Orange Peel, Fennel Seeds, and Camomile Flowers.

Boil all together in a gallon of strong ale, and when cold, clear it off, and add one pint of spirits of wine. If this be thought too strong, two quarts more of ale may be added. This is an excellent cordial both for healing and strengthening the stomach and bowels. These are the best methods of treating the above disorders, to which horses are often subject, and in which they are often lost for want of proper trcatment.

But before we conclude this chapter, it is necessary to observe that the scourings which succeed long-continued sickness, such as the Farcy, Putrid Fevers, or an inflamed state of the blood, where bleeding and other proper eracuations have been neglected, too often terminate fatally ; especially when the creature discharges a fotid slime, and when the same matter gleets from his nose; for in these cases the blood is dissolved, and the whole mass of the fluids is be come putrid, and discharges itself by those drains.

\section{Disorders of the Kidneys and Bladder.}

Inflammation of the kidneys and bladder are sometimes brought on by other disorders, and often by sprains, hard exercise, catching cold when hot, or from the want of proper care.

Stmptous of a Hurt in the Kidneys.-The horse is very weak in the back and loins; he stales with difficulty, is faint, eats very little; his eyes appear languid and of a dead color ; his urine is foul, thick, and often bloody, especially after a violent strain; be can not move backwards without great pain, which may be seen at every attempt. It is sometimes hard to distinguish an inflammation from a sprain, or what is called, "tifled in the back." There is no method but observing the gait of the horse. If he have got tifled in the back, he will be hard put to it to keep from coming down behind, and indeed will often come down; his eyes will look rather red, but his urine the same as before. A tifle lies in the marrow, or pith of the back.

Ccrk.-The principal remedy for a hurt in the kidneys is theeding. which should be done pretty plentifully, as by this 
means an inflammation will be prevented; and if you have reason to think that the inflanmation is already begun, from the creature's being feverish, and staling with great difficulty, the operation should be repeated; for unless the inflammation be Prevented, or immediatcly remored, the consequence will be fatal. But, although bleeding is the prineipal, it is not the only remedy, for rowelling is of great service. Put a rowel on each side of his belly, and give the following balls twice a day. in a pint of the decoction of marshmallows, haring an ounce of gum arabic, and an ounce of honey dissolved in it:

1 ounce of Salts of Prunella.

6 drams of Spermaceti.

2 ounces of Castile Soap.

Add as much honey as will make a ball; and if the urine be bloody, an ounce of Japan earth must be added. If the fever continue, you must repeat the bleeding, and give emollient clysters, and the cooling, opening drink, before reeommended for Fevers, till it abate. These methods will often prove successful, but sometimes the disease is too obstinate to be overcome by them, and the urine still passes with pain and difficulty. Recourse must then be had to the following balls, and they must be repeated twice a day till the horse stales without pain, and his urine becomes clear. and without any purulent settlement :

\section{1 ounce of Venice Turpentine. \\ 1 ounce of Castile Soap. \\ 6 drams of Nitıc. \\ 2 drams of Myrrh, in powder.}

Make the whole into a ball with honey, and wash it down with a strong decoction of marshmallows.

'These are the best methods of treatment in this disorder, and will in general prove successful. Sometimes indeed this malady is too strong for the power of medicine, and then the urine continues turbid, and daily becomes of a deeper color, with a fotid smell, a sure sign that the kidurys are ulcerated; which generally terminates in a consumption, and the creature becomes absolutely incurable.

In treating of the Colic I have recommended a method for remoring the Stranguary, when it proceeds from wind, or from dung pressing upon the neck of the bladder ; but sometimes it proceeds from an inflammation, and a retention of urine.

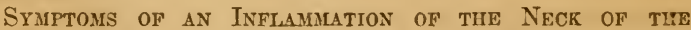
BLADDER.-When a horse is seized with a Stranguary from the above cause, he will make frequent motions to stille, 
standing wide and straddling, his bladder being full of urine, and his flanks distended; he will be uneasy, constuntly shifting his hind feet, ard often giving clicks in his motions; he also sometimes hangs his head, and then raises it suddenly.

Cure.-First bleed largely, and then gire the following:

1 ounce of Spirits of Sweet Nitre.

2 ounces of Syrup of Marshmallows.

1 ounce of $V^{\top}$ enice Soap.

Cut the soap small, dissolve it in a gill of hot water, put the abore to it, and give it to the horse. Repeat it every eight hours. Also dissolve an ounce of gum arabic and an ounce of nitre in a gallon of water, and let him drink plentifully of it. If he will drink it of his own accord, it is best ; but if not, horn a little into him, for it will greatly tend to remove the cause of the disease, and consequently to terminate the effects.

'There is a disease of the kidneys, viz. : a Diabetes, or profuse staling, which pruduces effects directly opposite. This disorder is seldom cured in old horses, as their fibres are become rigid, and unable to perform their office, a misfortune which all the power of medicine can not remove. But in young horses this disease is often cured, and the following method will generally be attended with success :

Cure of a Drabetes.-In order to cure this threatening disorder, great care must be taken not to let the horse drink too much water, and never to give him any moist food. Attention to these particulars will go a great way towards a cure : and instead of giving him common water to drink, give him lime-water; to make which, take about three pounds of lime, unslacked, put it intc a clean ressel, and for every pound of lime pour six quarts of water into it; let it stand three days, take the scum off the top, and gire the horse the water to drink. Be careful not to stir the lime at the bottom of the ressel. This is a very clear, wholesome water, and very good for many disoriters. In the mean time the following medicine should be given :

1 ounce of Peruvian Bark.
1 ounce of Japan Earth, in powder.
1 ounce of Irish Slate, do.

Gire these in lime-water, and repeat as often as needful.

Some Farriers give strong alum possets two or three times i day; but this kind of treatment cannot be proper, for the alum takes so fast hold of the juices of the stomach. that if the horse were not ill, it would be enough to make him so. 


\section{The Molten Grease.}

This is so common a disorder, that it ought to be weli understood; but, alas! like many others, it is often mistaken for something else. This disease is a melting down of the fat of the horse's body, caused by riolent exercise in very hot weather; or if the horse be full of flesh, it may happen in cold weather. Hard riding, or sudden colds, will bring on this disorder.

Symptoms.-It is always attended with a ferer, heat, restlessness, starting and trembling, inward sickness and shortness of breath. Also the horse's dung is extremely greasy, and he often falls into a scouring. His blood, when cold. is covered with a thick scum of fat, of a white or yellow color, but generally the latter. The congealed part, or sediment "ppears like a mixture of size and grease, and is so extremely slippery that it will not adbere to the fingers; and the small proportion of serum is also slippery and clammy. The horse soon loses his flesh and fat, the latter being probably dissolved into the blood. Such as have sufficient strength to sustain the first shock, commonly become hidebound, and their legs swell greatly; and in this state they continue till the blood and juices are rectified; and if that is not done efiectually, the Farcy, or an obstinate Surfeit, is generally the consequence, which can not be removed but with the utmost difficulty.

Cure.-In the first place bleed pretty plentifully, and repeat the operation two or three days successively; but take care that you take only a sinall quantity at a time after the first bleeding, as otherwise the creature would be rendered too weak to support himself, and his blood too poor to be easily recruited. As soon as he has been bled the first time, let two or three rowels be put in, and the emollient clysters prescribed for Fevers be thrown up daily, to mitigate the fever, and to cleanse the intestines from the greasy matter. At the same time plenty of water-gruel should be given, and sometimes a small quantity of water, with a little nitre dissolved in it. The latter will be of great service, as it will prevent the blood from running into grumous concretions, and proving the source of innumerable disorders, it not causing a total stagnation, and consequently the death of the animal.

The borse must be treated in this manner till the ferer be entirely gone, and he shall have recovered his appetite; and then it will be necessary to give him three or four purges, a week distant from each other, which will make 
him stale and perspire plentifully, and at the same time bring down the swelling of his legs. The following is well calculated for the purpose :

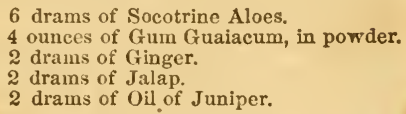

To be made into a ball with syrup of buckthorn. By pursuing this method the horse will soon be recovered, for this purge will mend his appetite, and increase his flesh. If it be too weak, add a dram more of aloes. It will bring down his swelled legs, and carry away all the superfluous natter that elogs the blood. When you give the physic, be careful to give plenty of warm water all the time.

\section{A Surfeit.}

Some people pronounce every ill-thriven horse surfeited, whether he is so or not. A Surfeit is nothing more than the effects of an ill cured disease, and therefore what is called a Surfeit in horses is very different to the disease which bears that name in the human body; the latter being the beginning of a disease, and the former the remains of one.

Sxuptoms.-The horse's coat will stare, look of a rusty color, and eren appear dirty, although the greatest pains have been taken to keep him clean. His skin will be covered with scales and dandrutt, which will appear like meal among the hair, and when cleaned off will be followed by a succession of the same matter, oceasioned by the perspiration being obstructel. Some horses will be covered with a kind of scab, sometimes moist, attended with heat and inflammation, and the humor so rery sharp, and causing so rioleut an itching, that the creature is incessantly rubbing himself, and by that means making himself raw in different parts of his body. Some horses have neitler scales, dandruff, nor scab; but look dull, sluggish, and lazy. Some are hidebound, and others afflieted with flying pains and temporary lameness. In short, the symptoms are very various, and almost as numerous as those of the seurry itself.

Catses.-The causes are as various as the symptoms. Some horses are surfeited by high feeding and want of proper exercise; which produce a bad digestion, and generate ill humors. Some are surfeited by unwholesome food; some by hard riding; some by drinking cold water when they are bot; some by bad or improper physic, and some by standing 
In stables through which the rain drups, or 7y lying wet. But as manr also get surfeited by standing when hot at the doors of public houses, such bad practices should be guarded agninst.

f Cusk-If we dnly consiler the nature of Surfeita, their fure will be much more easily perturmerl. 111 allow that they arise from a bad state of the blourl; but how is this to be remedied? By bleeding and purging. liut this must be done in a rery gentle mamuel. Take about a quart of blood, and the next day give the following ball:

\section{1 onnce of Socotrine Aloes. \\ 1 drain of Calomel, $\mathrm{Pp}$. \\ 2 drams (Oil of Aniseeds.}

Add as much lenitive electuary as will make it into a ball. Gire plenty of warm water to work it off. Repeat both bleeding and physic in eight days; and when the last dose is wrought otf. give him six ounce's of the cordial halls in a little warm ale. Also give a spoonful of the fullowing powders every day in a mash :

\section{4 ounces of Flonr of Firimstone. \\ 4 ouners of Crncis Metalorum. \\ 4 ounces of Nitre, in powder.}

Mix all up well together. By perserering in the abore method you may cure the most inveterate Surfeit, and if any scabs or runuings appear in the skin, rub them with the following :

\footnotetext{
4 ourres of Snlphar Tivum.

2 ounces of White Copperas.

2 ounces of White Hellebore, in powder.
}

Mix these powlers with churn-milk, rub the places affected well, and the grievance will soon disappear. Sometimes a Surfeit settles in the legs, and they swell much, and then break ont and run rery much. When this is the case, two taps put iuto the lower belly will be of great use. Staling balls should be given every third day, and plenty of warm water to work them off with. Make the staling balls as follows :



Bray all well tngether into a paste, in a mortar, and form it into a ball. The above is only for one dose. but you nay make as many as you think proper at onee, and keep them fur use. Give ther at vight, and they will work off the nexs 
day. These balis are of great serrice in many of the disorders of borses. and are some of the best staling balls yet found out.

By following the foregoing directions, a cure will generally be performed. Sometimes in this disorder little knots break out, especially mpon the hind parts of the horse, and these knots throw out a little matter. When this is the case, you must rub them with strong mercurial ointment. Sometimes these little tubes, or pustules, have living insects in them: but by rubbing them as I hare just directed you, they will be destroyed and the cure completed.

\section{The Hidebound.}

This disorder is too often brought on by the horse being worked too hard, and badly kept; although this is not always the case. When the skin of a horse sticks so close to his ribs that it appears immorable, the horse is said to be hidebound. But this is not properly a disease, but rather a symptom, being often caused by previous disorders, such as fevers, convulsions, surfeits, worıns, or disorders of the kidneys or lungs.

Cure. - As the hidebound may proceed from various canses, it is necessary to determine the cause. before such medicines can be applied as will remore it. If it owe its origin to hard labor and want of food, rest and plenty will soon remore it. If it be caused by worms, worm medicines must be applied; or if it be left by any imperfectly-cured disorder, the following drink must be given :

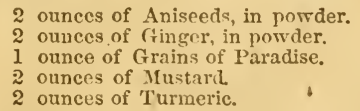

All to be powdered, and to be given in warm ale, fasting, and to fast two hours after. Bleeding, tapping and physic are also necessary, when the hidebound is left by any disorder.

\section{The Illange.}

This disorder is more shameful than dangerous. for you can not go abroad with \& seabbed horse without being hissed at, neither is it proper; for this disease is so infectious that every horse that may come near it will be in danger.

The Mange is too well known to need a long description, though some have been mistaken, and have taken a hot itcbing eruption for it. 
SrMptous.-At first it is confined to the skin, but by long continuance it ritiates and pollutes the blood. The skin is generally thick, and full of wrinkles, especially about the mane, the loins, and the tail ; and the little hair remaining on those parts stands erect. The ears and eyebrows are commonly naked; and when the limbs are affected, they hare the same appearance : but at the same time the horse is not raw, nor does the skin peel off as in a Surfeit.

Cacses.-The Mange is generally taken by infection, for it is so rery catching. that if a horse be put into a stable where one in the Mange has stood. before it be thoroughly cleansed, he will hardly fail being infected. But though infection is the general, it is not the only cause of the Mange. Low feeding. and running long abroad in cold, pinching weather, without sufficient provender, will cause a borse to have the Mange.

CrRE.- When the horse has been infected by another, the disorder is not so obstinate as when caused by starration, for the blood will not be in so bad a state. When you think a horse has got the Mange, apply the following where 5ou think it needful, and it will cure it at the beginning without much trouble or expense :
4 ounces of Sulphur Tirum.
4 ounces of White Copperas.
4 ounces of White Hellebore Root, in powder.

Mix all together in two quarts of butter-milk, and rub the places well By this method you can cure most scabs of short duration; but when once the Mange has got great hold, it will require sharper treatment. Make the following for one horse :

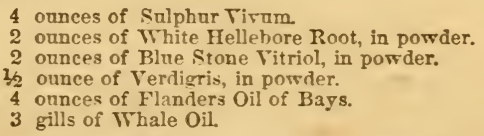

Mix all well together, and rub the horse well with it all orer-in the sun, if in summer. but before a fire if in the winter. In summer you must also turn him out to grass after rubbing. but in winter keep him warm in the honse. You must be careful to wash rour saddles and bridles, cart gears, stands, mangers. racks, \&c.. well with quick-lime and chamber-ley ; for if you do not clean all that the horse may hare nsed, the infection will remnin. You will find the abore a certain cure, if managed rightI 5 , for I hare cured hundreds with it, and I do not remember one instance of its failure. 
At the same time give freely of flour of sulphur and liver of antimony; and if you have a number of horses infected, be sure to rub them all together.

Some people say that when a horse is rubbed for the scab he will infect others, but I am of opinion that he will not, neither do I remember an instance of it.

\section{The Farcy, or Farcin.}

There have been many opinions respecting this disease. Some authors reckon five kinds; but although there are so many different branches, yet four of them have the same root. The Water Farcy is different from the others, and therefore I shall put it afterwards by itself. There is a scurvy which horses are subject to, and which is often called a Farcy; but it is no such thing, for there are only the two kinds of Farcy, which I shall here treat upon. Horses are often said to bave the Farcy when they have not, for sometimes when people do not know the proper name of a disorder, they call it the Farcy. The true Farcy is a disorder of the blood-vessels, and generally follows the course of the veins, and when inveterate, thickens their coats and integuments in such a manner that they become like so many cords.

Srmptoms.-At the beginning of this disorder a few small knobs or tumors, resembling grapes, are found on the veins, which are so painful to the touch that the creature shows evident marks of uneasiness on their being pressed with the finger. They are at first very hard like unripe grapes, but in a very little time they grow soft, and break and discharge a bloody matter, and become very foul and untoward ulcers. This disease appears in different places on different horses. Some show it first on the head; some on the external jugular vein; some on the plate vein, extending from thence downward, on the inside of the fore-leg, towards the knee, or upwards towards the brisket. In some it first appears about the pasterns, on the sides of the large veins, and on the insides of the thighs, extending towards the groin; in others on the flanks, spreading by degrees towards the lower belly; and some horses are nearly covered all over the body at once.

Cure.-When the Farcy attacks only one part of a horse, and that where the blood-ressels are small, it may be easily cured; but when the plate vein is affected and turns corded, and especially when the crural veins, withinsile the thigh, are in that condition, the cure is very difficult, and the creature is rarely fit for any thing but the lowest work after it- 
Therefore those who depend upon some particular medicine, and flatter thomselves with being able to cure erery species of the Farcy with it, will find themselres wretchedly mistaken; for different medicines are needful. according as the disease is superficial or inreterate. The former is easily cured, for sometimes moderate exercise is sufficient; but the latter requires knowledge and experience; and often baffles the most skillful. and defies the whole power of medicine.

From the above description of this disease it appears that it is of the inflammatory kind, and that the blood-ressels are affected. Copious bleedings are therefore absolutely necessary, especially if the horse be fat and full of blood. This evacuation always checks the progress of the Farcy in its beginning, but its good effects soon ranish, especially if the horse be low in flesh. After bleeding, mix the following :

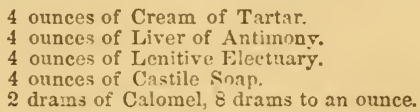

Make these into balls, and gire tro ounces a day for some time. While giving these balls, dissolre a little nitre in the water giren to the horse to drink. These medicines will keep his body open, and allay the inflammatory heat of his blood. which is the principal cause of the dise sse; and while they are given inwardly to remore the cause. let the tumors be rubbed twice a day with the following ointment:
4 ounces of Elder Ointment.
4 ounces of Flanders Oil oi Bays.
2 ounes of white Vitriol.
1 ounce of Red Precipitate.
2 ounees of Sugrar oi Lead.

Beat all well together into an ointment, and keep it for use. This ointment will soon disperse the tumors, which will leave small bald spots on the skin, but the hair will grow again in time. If the tumors break, and run a thick. Well digested matter, it is a sign that the disease is conquered, and the horse will soon be well; but it will be necessary to give him two ounces of liver of antimony every day for a fortnight. and two ounces every other day for a fortnight after, in order to sweeten his blood. and disperse the small bunches that remain. This method nerer fails when the small reins only are affected; and a short time will complete the cure.

But when the Farcy affects the large blood-ressels, the cure is far more difficult. Let the practitioner always attempt it at the beginning of the disease, as he then will have fever 
difficulties to encounter ; for delay renders that almost impossible to be overeome which at first might have been easily conquered. Therefore, when the plate or crural veins are corded, lose no time, but bleed immediately on the opposite side, and apply to the distempered vein the following mixture, which is proper to dress the wounds with, but ngt before they are broken out :

\section{1 dram of Corrosive Sublimate.}

1 ounce of Spirits of Salt.

Powder the sublimate, and put it into a bottle, and put the spirits of salt upon it to dissolve it; then add two ounces of vinegar, by degrees. This is a very proper mixture to dress the uleers with; but if it ean not be easily got, take

\section{6 ounces of Oil of Turpentine. \\ 3 ounces of Oil of Vitriol.}

Put the pot in water with the turpentine in it, and pour the oil of vitriol in, a little at a time, and keep stirring it till it shall have subsided. If the Farey be situated in the loose and fleshy parts, such as the flanks and belly, the mixture should consist of equal parts of oil of turpentine and oil of vitriol; but when the seat of the disease is in the parts which are less fleshy, the proportions above are best calculated to perform a cure. The medicine must be used in the following manner. Rub the parts affected with a woolen eloth. and then apply some of the compound oil to every bud and tumor. Continue this method twice a day, and at the same time give cooling physic erery other day. The balls and nitrous draughts before mentioned will answer the intention. By this treatment the tumors will be digested, and the cords dissolved ; but it will be necessary to give liver of antimony to complete the cure, and to prevent a relapse ; and also to dress the sores, when well digested, with a mixture of bees' wax and oil, which will heal them, and smooth the skin.

Sometimes the disease will not yield to this treatment, especially when situated near the flanks or the lower belly. In that case it will be necessary to bathe the parts with the compound oil, as far as the centre of the belly; and at the same time to give a course of antimonial medicines. The following composition is stronger than the last, and on that account is often used when the disease is obstinate :

\footnotetext{
4 ounces of Spirits of Wine.

2 ounces of $\mathrm{Oil}$ of Turpentine.

4 ounces of Oil of Vitriol.

2 ounces of Vinegar.
}

Mix all together, with the caution before directed. When 


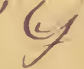

40

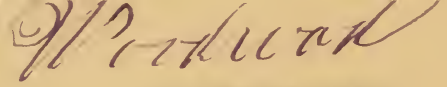

THE COMPLETE FARRIER,

this method fails, and the disorder becomes inveterate, try the following, which is recommended by an eminent practitioner :

1/2 pint of Linsecd Oil.

3 ounces of Oil of Turpentine.

3 ounces of Oil of Peter.

2 ounces of Oil of Bays.

$1 / 2$ ounce of Oil of Origanum.

$1 / 2$ ounce of Strong Aquafortis.

2 ounces of Barbadoes Tar.

2 drams of 'Tincture of Euphorbium.

Mix all together with caution, as before directed. This medicice must be rubbed on the tumors and corled reins once in two or three days, observing that if the months of the ulcers are choked up, or so thick as to confine the matter, to open a passage with a small hot iroul ; and also to destroy the proud flesh, which may be kept down by touch. ing it occasionally with oil of vitriol, aquafortis or butter of antimony.

In this disorder, these are the best ways of proceeding that have ret been discovered ; lut it is to be considered as an obstinate one, and is sometimes rery bad to cure. It has hitherto baffled many an able practitioner, and it is to be feared will baffle many more; fur when the blood has got into such a corrupted state. it bids defiance to medicines.

The ingenious Dr. Brackilen recommends the strong mercurial oiutment for rubbing the cords and tumors with before they break; and in order to disperse them when they are broken, to dress the sores with a mixture composed of equal parts of Venice turpentine and quicksilrer. If the month becomes sore by this means, a gentle purge shonld be given to prevent salivation. This is doubtless a rery good method, and if care be taken, will often prove effectual. He also recommends the following alterative ball :

\section{1 ounce of Liver of Antimony. \\ 1 ounce of Bezoar Mineral. \\ 4 ounces of Cordial Ball.}

Beat all well together, and give about the size of a walnut every day for some time, fisting, and to fast two or three hours after.

I have giren you the best prescriptions that I am able to give, and such as will not fail to cure if properly applied, if the horse be not incurable. I have been more particular in treating of this disetse. because it is common among borses, and very often managed improperly by those whis pretend to eure it. Such, therefore, as have valuable lorses in this clisease, would do well to be careful whom they em- 
ploy, and assiduous in observing the methods they make use of to eure it, if they do not think proper to attempt a cure themselves. In my opinion they may do it better themselves by following these direetions, than by trusting to farriers.

\section{The Water Farey.}

This disease varies very much from the last, and would more properly be called a Dropsy than a Farcy. There are two kinds of this disorder, but they are nearly of the same nature. One of them is produced by indisposition terminating in the skin, as is often the case in epidemical colds; the other is a true dropsy, where the water is not confined to the belly and limbs, but is found in different parts of the body, and a great number of soft swellings appear. When you press the finger pretty hard upon any of the swelled parts, or under the horse's belly, or on any part of the body, you may take it for granted that he has got the Dropsy, or what is called the Water Farcy.

This disorder mostly proceeds from foul feeding, or a continuance of very wet weather in the end of summer.

Crre.-Whenever the swellings appear, make scarifications, that is, holes through the slin. This may be done by a short fleam; and if you have not one short enough, put a collar made of a piece of leather on it. If the swelling be under the belly, strike a good many holes in at a time, but be careful to aroid the reins. By this means a great quantity of water will run out. Taps in the brisket are also often of great service. I have fleamed horses four or five times before I could get the swelling to subside. When the water has subsided, the blood is left in a bad state, to remedy which, a gentle purge should be given two or three times, eight days distance, to recover the crasis of the blood, and brace up the relaxed fibres of the whole body. Lime water is very proper, with a little nitre in it, and let the horse's food be warm mashes of bran, with a little malt in it. His keep must be increased by degrees. The disorder mostly happens to young horses that have not been used to high keep. You must give one of the following balls every day, omitting the time when the physic is working :

\footnotetext{
2 ounces of Squills.

1 ounce of Camphor.

1 ounce of Castile Soap.

$1 / 2$ ounce of Turpentine.

4 ounces of Yellow Resin.
}

Make these into a ball with honey, and give one ounce at a time. These balls will work the wator off by urine. Wheu 
the horse has been treated in this manner till the water is evacuated, and he begins to recorer, give him a pint of the following infusion erery day for a fortnight, fasting, and let him fast one hour after each dose :
4 ounces of Gentian Root.
4 ounces of Black Hellebore
2 ounces of Jesuit's Bark.
4 ounces of Camomile Flowers.
1 Handful of Centaury.

Boil all together in six quarts of water, for ten minutes, let it stand till cool, and then strain it through a cloth. This strengthening drink, will brace the fibres, cause the fluids to circulate quicker, and complete the cure.

\section{Founders.}

The Chest Founder is produced by riolent exercise on a full stomach, and drinking large quantities of cold branch water ; by the use of mouldy bran. corn, or oats, or by eating large quantities of green food, such as oats. wheat, peas, \&c, while performing hard labor. The seat of the clisease is in the lungs; the heart and liver are also considerably enlarged, insomuch that there is not room for them to perform their office with ease. The liver. lungs, diaphragm, and surrounding parts, are all corered with large brown spots, and are much inflamed.

SrMptoms.-A horse that is chest foundered, will straddle or stake with his fore legs, showing an unwillingness to bring his feet together; and if they are placed near each other, he will not permit them to remain so for a minute. Indeed, they are frequently twelre or eighteen inches apart, which is caused by a fullness and continual uneasiness about the chest: the carity being ton small to contain the lungs, \&c., in their enlarged situation, with ease. The hind legs are free from the palsied appearance of those before, and it is not difficult to distinguish it from a common founder, as it is wanting in all its symptoms, except the stiff and numbed appearance of the legs.

Large bleedings, and half an ounce of aloes given inter-, nally in a ball, have sometimes aflorded momentary relief. A horse laboring under this disease, is worth but little more than his board, as he is unable to bear fatigue, or undergo severe serrice.

The Common Founder is caused by riding the horse until much heated and fatigued, and the allowing him to cool suddenly, by drinking freely of cold water, or standing in an exposed situation, or in a cold stable without covering; or, 
withont sulden cooling. it may be produced by too bountiful feeding, and his swallowing his food greedily, while very warm and hungry. Under such unfavorable circumstances, the poor aninal. after resting, instead of being refreshed, is stiff and sore ; his rest, food, and drink, being more destructive to health than constant action and abstinence. On the contrary, had he been allowed to cool gradually, and fed sparingly, he would have escaped injury.

CurE.-Take from the neck rein a gallon of blood, and give as a drink, in a quart of strong sassafras tea, a tablespoonful of saltpetre, and a quarter of an ounce of assafoetida ; withholding any drink for six hours; at the end of which, should le not be better, take half the quantity of blood, repeat the drink, offering him bran or oats scalded with sassafras tea, his drink being mixed with tea. His feet should be well cleaned, and filled with cow dung.

Other Reuedies.- - As soon as your horse is foundered, bleed him in the neck in proportion to the sererity of the case. In extreme cases, bleed him as long as he ean stand. Then draw his head up, and, witls a spoon, lay salt back on his tongue, till he has swallowed one pint. Let him drink only moderately. Anoint his feet with spirits of turpentine, and he will soon be well. The founder pervades every part of the system. Bleeding arrests it in the blood, and the salt in the stomach and bowels. Attend to it immediately after the injury.

The Prairie Farmer recommends, as a simple and certain cure, to bleed the horse freely in the neck, as soon as tha founder is discurered. and as soon as practicable, place him in water about up to his belly-the colder the better-and let him stand two-thirds of a day; or, if badly foundered, longer. This drires the founder from his feet and legs, and prevents its settling there.

\section{Poll Evil.}

This disease in the horse proceeds sometimes from striking the poll of his head against any hard substince. or from bruising the part with the halter, which canses it to swell. First abate the inflammation by bleeding, physic. and the apblication of cold lotions to the part. This will sometimes di-perse the swelling. If it matters, hasten its formation with warm fomentations, poultices, or stimulating embrocations; then open the swelling so that the voliole of the matter should run out, and continue to do so. This is done by a seton Keep it clean with warm water. $\Lambda$ piece of the skin 
of old bacon rubbed on with a hot iron, is a good application. Poll Evil has been cured by the following mixture (apparently at least by it in some instances.) Take finely pulverized nint glass three spoonsful. put into urine, one pint in a bottle, and bury it in the gromnd for three or four days ; after which take one spoonful or more of the mixture, well shaken up, and put that much into each ear, once a day for. three, four or five days.

\section{A Sprain in the Back.}

All kinds of Sprains resemble each other. They are a relaxation of the tendinous fibres. from the muscular part; being overstretched. Sprains in the back are mostly caused by overweighting the horse, or by his losing his hind feet oll the side of a bill; and sometimes by putting him back too quickly. There is much difference between a Sprain in the back, and what is called tifled in the back. Sometines a horse catches cold in his loins by having his clothes or his saddle taken off when he is hot, and being turned out of doors; and some horses are subject to Rheumatics, which make them lame in many places, and are generally taken for Sprains.

To cure a sprain in the back, first bleed pretty freely, and then give the following drink:

1 ounce of Tincture of Guaiacum.

1 ounce of Balsam Capivi.

1 ounce of Oil of Juniper.

To be put into a quart of strong parsley-root tea; half to be given at night, half in the morning, and plenty of warm water to work them off.

Also, lay a sheep's skin with the flesh side to his loins for six or eight hours, if he can bear it; and then turn the wool side to him, and let it stay on a day, and when you take it off, sheet him well for fear of catching cold. Also, make a plaster of the following:
2 onnces of Oxycroseum.
2 ounces of Paracellis.
2 ounces of Red Dominion.
2 ounces of Burgundy Pitch.

Melt all together, and lay them on pretty warm, and put a little wool, clipped short, on the charge while hot, and then pour on a little cold water to fasten the whole together. These are the best methods I am acquainted with, and if properly pursued, and the mixtures carefully made, liere will be prompt relief. 


\section{A Sprain in the Shoulder.}

When the shoulder of a horse is sprained, he does not put out the leg like the other, but in order to ease it sets the sound foot firmly on the ground. When trotted in hand he forms a kind of circle with his lame leg, instead of putting it forward. and when he stands in the stable that leg is advanced before the other.

There is what is called a Shoulder-slip, which is worse than a Sprain. When this happens, the horse can neither lift his leg nor put it forward. You may know this by the shoulder-blade standing higher than the other; but to diseern that, you must make him stand on the lame leg, for the leg he stands on will always appear a little higher than the other. The flesh will also shortly waste away from the shoulder-blade, which is a sure sign of a Shoulder-slip. When this accident has taken place, put a tap in the lame side of the animal's breast, and blow the shoulder full of wind with a pipe. When you have rinded the skin to put the tap in, hold the skin fast to the pipe, and blow the part that you have rinded full, and let some one draw the wind up into the shoulder with the edge of his hand as far as the top of the shoulder-blade, and then put in the tap. or rowel, and stop the hole up well with tow and salve Give warm water for three days, and then open the place, stir the tap round, and rut the shoulder all over with the following liniment:

2 ounces of Spirits of Wine.

2 ounces of Sweet Oil.

2 ounces of Spirits of Sal Ammoniac.

Shake them well together, rub the shoulder well with the mixture every third day for some time, and if the horse do not get better with three or four times rubbing, use the following :

\footnotetext{
2 ounces of Oil of Turpentine.

1 ounce of Oil of Origanuin.

1 ounce of Oil of Bricks.
}

Shake these up together. rub all on at a time, and walk the horse abont a little afterwards. When near the sea, swimming in the salt water is rery proper, and I have known, swimming in fresh water to be of great use, particularly in clear running streams.

A sprain in the shoulder point requires nearly the same treatment as a slip, but you need not blow it. When it is attende1 by inflanmation, eooling mixtures, such as extract of lead and wate., mmat be used. But when a swelling or an inflammation takes place, it is mostly caused by a hurt, 
or by a stroke from another horse. If there be no strelling, rub the shoulder point well with the following mixture every third day:

1 ounce of Oil of Peter.

1 ounce of Oil of Amber.

1 ounce of Oil of Spike.

1 ounce of Oil of Bricks.

Shake these well together, and rub the shoulder point evey other day. If the horse be not better, take
1 ounce of Oil of Turpentine.
1 ounce of Oil of Origanum.
1 ounce of Oil of Swallows.
1 ounce of Oil of Amber.

Shake these together, and rub the shoulder point well with them every third day; and if the horse continue lame, recourse must be had to blistering.

\section{A Sprain in the Coffin Joint.}

This is often a grierous disease, and it is difficult to discorer where the lameness is. It is often neglected till the joint grows stiff, and then the horse pitehes upon his toe, and is afraid of bearing any weight upon his foot. If you press with your thumb in the hole in the horse s heel, and upon the cornet of his foot, you will soon discover whether the hurt is in the Cofin Joint.

When people can not tell the cause of a horse's lameness, they often say that he has got sprained in the coffin. In $\mathrm{my}$ opinion it is better not to doctor a horse than to apply stuff to you know not what. If people wonld liare a little patience. most lamenesses would soon show themselves, especially a Sprain in the Coftin Joint. for it would raise a ring -round the corner of the foot, not much nnlike a Ring-bone, but closer to the foot.

The first thing to be dune is to draw a little blood from the spurn rein, then mix an equal quantity of oil of bays, or oil of origanum, beat well together, and rub well all round, just above the hoof. Apply this for three or four days together, and if no better, you must have recourse to repeated blistering.

\section{A Sprain in the Back Sinews.}

This kind of Sprain is more frequent among horses than any other, and is so common that I need not describe it, but only inform you how to cure it.

If it be recent, bathe the leg with a little hot vinegar, or verjuice, with a little saltpetre dissolved in it, and put round 
it a proper bandage; or, curriers' shavings, wetted with a composition made of vinegar, spirits of wine, and a little tar, and laid on the swelling with a pretty tight bandage round them, will be of great use. Take it off once a day, and soak the shavings again. or get fresh. Injuries of this kind must not be expected to be removed immediately. Rest is absolutely necessary, and turning the loorse out to grass would be of great service as soon as the swellng disappears, but not before. If these methods fail, the next thing is to blister ; for I have known blistering succeed when all the former have failed. The last thing to have recourse to, is firing; and this must he done carefully, and by some experienced person.

\section{Sprains of the Knees and Pasterns.}

The knees are liable to many misfortumes besides sprains. The Speedy Cut is done by striking one foot against the other leg. just below the knee, and is frequently done by a horse that trots high. Sometimes it swells very much, and is taken for a sprain. Sometimes horses get kicked by others, or meet with some other accident which causes a swelled knee, which is sometimes bad to remove. A poultice, made as follows, and caretully applied to the part injured, will have a great tendency to remove the swelling :

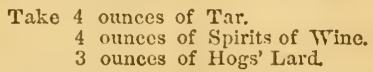

Melt these together over a slow fire, and be careful not to set fire to them, and put in as much linseed-meal as will make them of a proper consistence. This is a very good poultice for many other kinds of swellings, and although but little known hitherto, I hope that it will be found of great service. If any substance be left which will not give way to this method, you must lay on a little blistering ointment.

\section{Lameness in the Stifle.}

The Stifle is the tenderest part of a horse, except the eye. How many horse's have lost their lives by misfortunes in this part, and how many have been left lame by not being properly cured! A horse that is lame in the stifle generally treads on his toe. and can not set his heel to the gromnd without great pain and diffioulty. When you find this is the case, bathe the part well with warm rinegar; and if a puny swelling appear, foment it well with a woolen cloth wrung out of hot vinegar, wormwood and rosemary, having 
added half a pint of spirits of wine to a quart of the decoction. Let this operation be continued till the swelling is nearly gone.

Owners of horses should watch closely for this lameness. They cannot be too careful of the feet of their animals. You should examine the feet of your horses frequently, and with much minuteness.

When a horse has got a stroke and cut by the heel of his shoe, great care must be taken to keep out the cold air, and to keep him from drinking cold water, especially in winter time; for if the horse take cold, and an inflammation come on, there is reason to fear that death will follow. When you perceive that a horse has got a stroke and is cut through the skin, bathe it well with the following mixture:

2 ounces of Spirits of Wine.

1 ounce of Spirits of Sal Ainmoniae.

1 ounce of Oil of Amber.

Shake all well together, bathe the place well with it, and lay on a diachylon plaster with gum, in order to keep out the cold. If the horse grow very lame, and the place swell much, foment with the following:

Take a handful each of Trormwood,

Elder Leaves, Camomile Flowers,

Juuiper Berries, Marshmallow Leaves.

Boil in 2 gallons of Chamber-ley.

If the abore can not all be got, take double the quantity of juniper berries and camomile flowers, and foment for some time, as before directed; and when you leave off fomenting, rub with the above mixture. Be careful to wrap the part up warm, and as soon as it comes to matter, dress it with basilicon ointment. If any brown lee appear, syringe tincture of Benjamin, or balm drops, into the wound. When a callous substance, or proud flesh appears, eat it off with red precipitate. These are the best ways of curing a horse that has got lamed in the stifle.

\section{Lameness in the Cup-Bone, or Whirlebone.}

A lameness in this part of the hip is discorced by the horse's dragging his leg after him, and dropping backwards on his heel when he trots. If the muscles of the hips only are injured, the lameness may be soon cured; but if the ligaments of the cup are affected. or relaxed. the cure is often rery tedious; and when the cup is full of glueish liquor, the cure is doubtful. I have known the ligament which holds the hip bone in the cup to be broken, and then the hip bone 
hias come loose ; but this seldom happens, and when it does, nothing can be done to relieve it. When a borse is lame in the cup-bone, rub him well with the following mixture:

1 ounce of Oil of Amber.

1 ounce of Oil of Bricks.

$1 / 2$ onnce of Oil of Origanum.

1 ounce of Oil of 'Turpentine.

Shake these well up, rub one half on the cup, and the other half the third day. I have known this mixture remove the complaint when of long standing; but if it fail, you must try what blistering will do. The last thing to be tried is firing. I have fired horses that have been lame above a year, and eured then by it.

It is very easy to fire a horse in this part. Take the iron and make a circle, eight inches in diameter, like a cart-wheel, with scores about an inch asunder. Cut nearly through the skin; and if you do cut through in some places, it will be no worse. Then lay on the following charge :

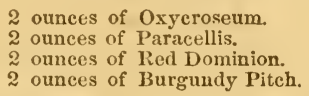

Melt these all together, lay them on pretty hot, lay a little wool, clipped short, on before it cools, and then a little water on to fasten all together.

Sprains in the Fetlock, or anywhere in the limbs, may be treated in the same manner, and if the oils will not remove the substances, blisters will; therefore I shall give you a recipe for a blister which is not only suitable for those complaints, but for other's where a blister is wanted.

$$
\begin{aligned}
& \text { Take } 1 / 2 \text { ounce of Quicksilver. } \\
& 1 / 2 \text { ounce of Venice Turpentine. } \\
& 2 \text { ounces of Flanders Oil of Bays. } \\
& 1 / 2 \text { ounce of Fum Euphorbiam. } \\
& 1 \text { ounce of Spanish Flies. } \\
& 2 \text { drams of Oil of Origanum. }
\end{aligned}
$$

Rub the Tenice turpentine and quicksilver well in a mortar for some time, anil then put in the oil of bays and rub for some time longer, till the quicksilver is quite killed. Powder the gum and flies well, and wix them all together. When you laty the blister on, lub it well against the hair to get it to the bottom; lay it on with a broad pointed knife, and cover it with a cloth, or the horse will get his mouth to it. This blister will answer any purpose you want a blister for, but you nust observe that there must be fifteen days between the times of laying it on. 


\section{The Pone-Spavin.}

Although this is a common disorder among horses, yat it is little understood by either breeders or farriers. The Lonespavin is a bony excrescence, or hard swelling, on the inside of the hock of a horse's leg, and sometimes owes its origin to kicks and blows, and sometimes to natural causes ; but in the former case it is much more easily cured than in the latter; and those that grow spontaneously on colts. or young horses, are not so bad as those that appear in horses that have arrived at their full strength and maturity. In old horses they are generally incurable.

Sometimes the horse is very lame when the Sparin is first coming ont, and when it has come out is better for some time, and then grows lamer again as the bone hardens. I would advise you to apply a blister as soon as you have any suspicion that a horse is likely to put out a spavin, and to continue blistering, every fortnight, for some time, by which means you may stop a Spavin in a young horse.

Ccre.-Mild medicines should be used if the horse is young, as they will in a short time wear the tumor down by degrees, which is much better than trying to remove it at once by severer methods, which often have a very bad effect, and produce worse consequences than those they were, intended to remove. But in full-grown horses other treat ment is necessary. The following ointinent is probably the best that can be used:
2 ounces of Cantharides.
4 ounces of Mereurial Ointment.
3 ounces of Tincture of Iodize.
4 ounces of Turpentine.
3 drams of Corrosive Sublimate. Mix with 2 pounds of Lard.

Cut off the hair from the part affected, and grease theroughly with the ointment thus made, rubbing it in well with the naked band. Let it remain two days, then grease the part with lard. In two days more wash it off with soap and water, and then apply the ointment again. Continue this till a cure is effected. By these means Bone-sparin may often be cured; but when they fail, recourse must be had to firing.

Before you fire a horse for the Bone-spavin, be carefil to take the vein out of the way. for it generally lies over the Spavin, and you can not fire deep cnongh to come at the callous substance without its removal. In order to destroy the vein, cut a nick through the skin upon it, just below the Spavin, and another just above it, and put a crooked neerle 
under the vein. and tie both ends : then cut the vein across between the tyings, both above and below, and you may either draw the piece of the vein out or leave it in. Let the iron you fire with be pretty sharp; cut four or fire nicks upon the bone, and let the iron take hold of the superfluons bone, in order that it may waste away by mattering; and when you have done, lay on some white pitch, pretty hot, and put a cloth round it to keep it on. In three days open the place and dress it with yellow basilicon.

\section{The Blood-Spavin, or Bog-Spavin.}

Many farriers and horse-dealers divide this disease into two heads, and give them different names; but to my certain knowledge they are both one, for I hare proved it in many ways. A Blood-spavin does not come by breeding from spavined mares. nor by being got by spavined horses, as the Bone-spavin does; but you may safely breed out of a Bloodspavined mare, or have the foals got by a Blood-spavined horse. In my opinion Blood-spavins are generally brought on either by Sprains, or hard labor when the horse is young, and sometimes when he is full-grown.

The Blood-spavin, or Bog-spavin, is a dilation of the vein that runs along the inside of the hock, and forms a small soft swelling in the hollow part, which in time renders the creature lame, but seldom till the gelatinous matter becomes ropy, like melted glue in a bag, and is situate on the inside of the hough. Sometimes it goes through the back part of the joint, and then it is called a thorough-pin.

Curk.-Soon as you discorer the rein puffed up, or forming a bag, lay on some blistering ointment, and in four days after bathe the swelling well with hot vinegar, with a little saltpetre dissolved in it. Aiso put a bandage round it to disperse the swelling as much as you can. If this method do not succeed, you must make two incisions in the skin lengthwise, as the vein runs, one just above, and the other just below the joint, and lay the rein bare: then put the end of a buck's horn under it. raise it up, and fasten it in both places with waxed thread: then cut the vein in two at both places, within the tyings, and if you think proper, draw the vein out. This method of proceeding will cure most Bogsparins at the beginning. The Blood-spavin may also be eured by applying the same ointment used in Bone-spavin, only it should be applied once in six days instead of once in four. This spavin ointment is very powerful, and when properly used is the best ever invented. 


\section{A Corb.}

This is a soft swelling that rises out of the joint on the back part of the hind-leg. just below the hock, and mostly lames the horse besides being uupleasant to the ere. To cure it, strike a few holes into it with a pricker. made so as just to go through the skin, then rub well with oil of origanum, and blister as often as needful. It this will not answer, use the Sparin ointment once in six days.

\section{A Ring Bone.}

This is so well known that I need not describe it. but only point ont the remedy ; yet I must observe that a Sprain in the Coffin is sometimes taken for a Ring-bone, when it causes a rim to rise just above the foot. ling-bones come ont from the pastern, between the fetlock and the foot; but if the pastern is long. they are nearer the foot. "1 hey will generally yield to the same metho:l of cure as a Corb. especially if just coming out, but if not, use the sparin ointment in same manner as in Bone-spavin, only do not apply it so often. Once in six days is often enough.

\section{Mallenders and Sallenders.}

The first is on the fore-leg, at the bend of the knee. and the last on the hind-leg. at the bend of the hough. They crack and throw out a thin brown matter, and sometimes, a bard scurf, or scab. which prerents the horse from bending the limbs which are affected as he should do.

Ccre.-They both proceed from the same cause, and consequently require the same treatment; which consists in washing the parts with old chamber-ley, or a warm lather of soap-suds, and afterwards applying strong mercurial ointment, spread on tow, to the eracks. once a day till the scabs fall off, when the cure will be completed; and then it will be necessary to gire hin a close or two of physic. If the disorder will not yield to the mercurial ointment, make a strong mixture of vitriol water, and wash the cracks with it, and it will dry them up, and cause the scabs to fall off.

\section{The Strangles.}

Most horses have this disorder while young, but at seren years old they are out of dinger. There are two kinds of this disorder. The common lind is a swelling under or between the jaw-bones. The other, which is called the bastard kind, is much the worst. Sometimes swellings appea: 
on the buttocks, break, and discharge matter for a few days, and then dry up, after which others appear in a fresh place in the same manrier. I have known horses that have had this complaint eight or ten weeks. The common kind begins with a swe!ling between the jaw-bones, which sometimes extends to the muscles of the tongue, and is often attended with so much heat, pain and inflammation, that before the matter is formed the creature swallows with the utmost difficulty.

Sruptous.-The Strangles is attended with great heat and fever, a painful cungh, and great inclination to drink, without being able. Some horses lose their appetites entirely, and others eat kut very little, occasioned by the pain resulting from the motion of the jans in ehewing and swadlowing. When the horse runs much at the nose, it is not a good sign. Although this disease is very troublesome, it is not dangerous, except when the swelling turns upwarls against the wind-pipe and gullet, and then there is dauger of suffocation if it do not break soon.

Cure.-The Strangles is not properly a disease, but a discharge common to young horses, and therefore it follows that the discharge must be promoted in order to throw off the offensive matter. The best method of doing this is to keep the swelling always soft by soaking it with softening ointment, such as narshmallows, or elder ointment. I have hnown oil of swallows. with a little spirit of hartshorn in it, to be very useful in bringing the swelling forward and caus. ing it to break. A cloth in the form of a cap. put on the hor'se's head, and stuffed with wool to keep the swelling warm, will be of great service. Some people apply a poultice, but there is no need of this if the above be properly used. Give plenty of warm water, with a little meal on it; for in this disorder a horse can not swallow dry food enough for its support. When they gather and break, see that the matter rums freely; if not, open them with the point of a sharp knife. It will be five or six days before they break.

When the swelling is broken, and the oritice of a proper size to discharge the matter, dress with the following ointment spread on tow :

Take 1 pound of Yellow Resin.

1 pound of Burgundy Pitch.

$1 / 2$ pound of Honiy.

$1 / 2$ pound of Common Turpentine.

11/2 pounds of Hog's Lard.

4 ounces of Beeswax.

1 ounce of Verdigris, finely powdered.

Melt the ingredients together, but do not put the Verdi. 
gris in till nearly cold, and keep stirring all the time till cold. or the Verdigris will fall to the bottom. This is one of the best salves for wounds that has been found out, and especially for old ones.

The Bastard Strangles requires the same kind of treatment, but it is proper to give the horse some calomel physic also.

\section{The Glanders.}

This disease has baffled all who hare tried to cure it, and probably will do so to the end of time; so I advise those who may have a glandered horse, to put him off as soon as they shall be certain that he is so. People often mistake other disorders for the Glanders. A violent cold sometimes causes a running at the nostrils, and kernels under the jaws, when the horse is free from the Glanders. Sometimes a running at the nostrils is caused by laying too much weight on a horse. I do not pretend to cure Glanders.

SyMPToMs.-The matter discharged from the nostrils of a glandered horse is either white, yellow, greenish, or streaked or tinged with blood. When the disease has been of long standing, and the bones are fouled, the matter turns blackish and becomes very bad. The Glanders is always attended with a swelling of the kernels, or glands under the jaws, but in every other respect the horse is generally healthy and sound, till the disorder has continued some time, and the morbid matter has affected other parts. If a thin, limpid fluid be first discharged, and afterwards a whitish matterif the gland under the jaw do not continue to swell, and the disorder shall have been recently contracted, a speedy cure may be effected by applying the following:

1 ounce of Roach Alum.

Powder these well, put them into a pint of warm vinegar, and syringe about an ounce up his nostrils every day. This may do good if the disorder be newly caught.

\section{Swellings and Imposthumes.}

When a swelling is in its first stage, bathe it well with verjuice or vinegar. with a little saltpetre dissolved in it; and if the swell still continue, mix
1 ounce of Extract of Lead.
1 ounce of Spirits of Wine.
1 ounce of Spirits of Sal Ammoniac.
3 ounces of Vinegar.

Rub the swelling well with it; but if it be very hot, add 
four ounces of water instead of the vinegar. Should the swelling come forward and form matter, which you may feel by the pressure of your finger, let the matter out, but be sure to make the incision large enough that you may dress it with ease. When you have laid the part open, dress it with the green salve before recommended, on tow, for you can not have a more proper salve. The next time you dress it, that is the doy after, make a wash of the following:

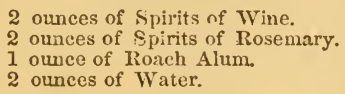

Mix these all together, and they will answer the purpose extremely well. When you have washed the wound with the above mixture, lay on a little green salre, on tow. and bind it on if you can, but if you can not, lay on a plaster to keep it on.

Some swellings, such as have been caused by bad barfen. on the shoulders, or blows on the legs, will not submit to weak mixtures, nor come to matter in a reasonable time. Mix the following, and it will either take them off or bring them to matter :

2 ounces of Oil of Spike.

1 ounce of Oil of Amber.

$1 / 2$ ounce of Oil of Origanum.

1 ounce of Oil of Turpentine.

Mix these well together, and rub the swelling well with them every other day. I have known this remove obstinate swellings.

\section{Wounảs.}

Wounds are caused by accidents of various kinds. When the skin is much torn from the flesh, if you are at hand while the wound is quite fresh, take a square-pointed needle and a waxed thread, and sew it up. Mind to put the needle in straight, one side over against the other; draw the skin tight, and tie a knot; cut off the thread, and then take another stitch about an inch off, and so proceed. When some people sew up a wound they do it the same as they would sew up a piece of eloth, but that is quite wrong, for they should tie a knot at erery stitch. and ent the thread off. But when you do not see the wound until the place is growing dead, and the skin is drawing up, then take off the loose stin; for if you keep it on it will curl up, and leave a blemish. Always keep the lips of a wound down.

When a wound is upon or near a joint, there is danger of 
throwing out a joint-lee, of which there are three linds. One, and mostly the first, is thin and bromn, something like sweet wort ; the second is rather thiclier and tougher, something like melted glue; and the third, which is the worst. is like muddy water and snort mixed together. This last has deceired many people; for when the wound has thrown out this kind of lee, with little white slippery pieces, something like matter, it has often been taken for such. When you find any of these kinds of lee, get a bottle of Riga Balsam, and syringe the wound every day. If Riga Balsam can not be got, use Tincture of Benjamin. I have known fomentations be of great use, especially on the stifle joint. When a wound is of a dead color, and the lips rise. and the dirty lee flows profusely, the cure is to be despaired of: If proud flesh arise when a wound is in a fair way for healing, take

1 ounce of Basilicon.

2 drams of Red Precipitate.

Mix them well together, and lay them on the proud flesh. This ointment is also very proper to dress a wound with that appears dead, and does not discharge a proper matter. If the proud flesh do not submit to the above, lay on a little blue vitriol, in powder, or touch it with caustic or oil of vitriol; and should none of these make it give way, lay on a little corrosive sublimate. The salves, tinctures and mixtures already laid down, are sufficient to cure any curable wound.

\section{Hurts in the Feet.}

Horses are oftener hurt in the Feet than any where else, and those hurts are often received from the blacksmith. Every blacksmith should be a farrier, and every farrier a blacksmith, for these businesses should go hand in hand. Sometimes a horse is lamed by being shod into the quick. The foot should always be carefully examined on the first appearance of lameness. Sometimes a nail with a flaw in it will cause a great grievance, as one part will come out and the other will go into the foot. Blacksmiths should never use such nails except in a frost, when they can put them into the old holes. Sometimes they leare stumps or pieces of nails in the feet; and sometimes when they drive a nail they turn the point into the foot, and then draw it back and put in another, taking no further thought about it, and when the horse becomes lame they say he is gravelled.

When a horse has got lamed in the foot, be careful to cut it well out, and to damage the hoof as little as possible, and 
dress the place with oil of turpentine, spirits of tar, and common tar. Lay no hot drying drugs on, unless proud flesh rise.

Sometimes corns on the heels cause a horse to be lame ; cut thein out, and dress the place with aryafortis. There is another fuult which blacksmitis are guilty of, and which is a great hurt to a horse. that is, cutting or piring the heel down too much. The heel being best to come at, they clap the paring-knife there and eut them down, when there is no need to take any off' them at all. 'The heels are the greatess support of the horse, and by paring them too thin, both corns and lameness in the back sinews are produeed.

Before a blacksmith begins to shoe a raluable horse, especially a road-horse, he should examine how he stands and how be goes. If he go low, heavy shoes should be used; but if he go high, light ones. If he turn his tces out, he will eut with the heel, and if he turn them in, will cut with the spurn. If he have a thin, flat foot, he should have broad shoes; but if a hollow, dished foot, narrow ones. If the erust be thin, and the rein near, small nails should be used. Some horses are hoof-bound-that is, have siraight heels which pinch the rein between the hoof and the coffin. When this is the case, thin the soles of the feet till the blood springs through, and then put on screw-shoes, and screw the feet ont. Let the screw-shoes stay on a fortnight. You may screw the feet out more than half an ineh.

The next thing to be considered is gravel risiug from the bottom to the top of the foot, and breaking out at the cornet How many twitter-bones have been flus formed that might have been prevented! When the gravel comes up to the top of the foot, take away the sole at the bottom, and the hoof at the top, and mix equal parts of oil of turpentine and oil of origanum, and bathe the top part of the foot. This will prevent a twitter from forming.

\section{A Twitter-Bone.}

A Twitter-bone makes a horse rery lame. ald not fit for work. It keeps throwing a tough white matter out of what is called a pipe. In order to cure it, first find out where the pipe leads. 'This you may do with a piece of round lead, the size of a small quill-barrel. Have the following ready, viz. :

1/2 an ounce of Sublimate, in fine powder.

1 ounce of Spirits of Salt.

Add juice of one lemon when Sublimate is dissolved.

Mix all together. and syringe a squirt full into the pipe when you take the lead out; and when you draw out the 
point of the syringe, put your thumb upon the place to pre. rent it coming back again. and then put on a pledget of green salve and tow. Do this ecery other day, for three or four times, and by this method most twitters may be remored. But if this method fail, the next thing to be done is to put a hot iron, the thickness of a small finger, where the pipe leads to, and to fill the hole with sublimate, and bind on it a pledget of green salve with a cloth. Let it be five days, and then lay on some more salve and tow, and in five days more the Twitter-bone and pipe will come out. The wound must be washed with the following mixture, and dressed with green salve and tow every other day, till nearly well :

1 ounce of Bole.

1 ounce of Oil of Origanum.

4 ounces of Oil of Turpentine.

Shake them up well together, and they will both help to heal the wound, and to bring down the substance. If any more Twitter-bones or pipes form, you must take them out in the same manner.

\section{A Fistula, and Bruises of the Withers.}

The Withers are much subject to bruises, caused by bad saddles, or such as are too wide in the front; but, whatever be the cause, it is well known that by neglect they often terminate in a Fistula.

When the Withers are bruised and a swelling appears. lay a poultice of bran and vinegar over the part. People who have a horse which is crushed in the Withers, and pay no regard to it, are worse than savages, and are not fit to have such a useful animal.

Crre.-After a horse has been bruised in the Withers, the skin breaks and matter is discharged, and then the owner supposes that the abscess will subside, but he is often mistaken; and the pipe which he perceives throwing out matter, is at the same time running forwards in the Withers, and forming a Fistula. When you find the disease proceeding in this manner, lay the pipe open with a sharp penknife all the length, for if you leave any umopened, it will form a Fistula. After you have laid the place open, dress it with the following mixture :

\footnotetext{
4 ounces of Potashes.

4 ounces of Honey.

2 ounces of White Vitriol.

1 pint of Vinegar.
}

Boil all together, wash the wound well with the mixture, 
and lay on the green salve and tow. If the abore be not dry enough, add two ounces more of white vitriol, and two onnces of bole. These will make a salve by themselves: and by these methods you may cure any disease of the Withers arising from external injuries.

But tumors often arise in the Withers from internal causes, such as the crisis of Fevers. When this happeus, you must not attempt to stop it, nor use any thing to put it back, for by this means sou would drive it more into the shoulderblades, and make it worse to cure; but. on the contrary. do every thing you can to assist Nature in bringing it forward. You can not do better than lay on poultices twice a day till it breaks, for reason tells us that it is better to do so than to cut it; but when it is broken, open the orifice with a knife, that you may have more freedom in dressing it ; but be careful in using the knife, that you do not catch hold of the ligament which turns along the neck to the Withers. Sometimes it runs to the other side of the neck. under the Withers. The cure is the same as before. Lay all the cavities open with the knife, and do not cut across if you can avoid it. Then take the following never-failing mixture to dress with :

4 ounces of Crude Sal Ammoniac.

2 ounces of Bole.

8 ounces of Honey.

2 ounces of Pearl Ashes.

2 ounces of White Vitriol.

1 pint of Vinegar.

Boil all together, and apply it to the wound every day at tirst, and afterwards every other day till well.

\section{Warbles, Girth-Galls, and Plushes from Saddles.}

These grievances are commonly known, and the following mixture will eflect a cure, take oft the soreness, and leave the skin kind. I may affirm that it is one of the best recipes yet found out for the purpose :

\footnotetext{
2 ounces of Extract of Lead.

$1 / 2$ an ounce of White Copperas.

2 ounces of Spirits of Wine.

4 ounces of Soft Water.

1 ounce of Spirits of Sal Ammoniac.
}

Mix all together in a bottle, keep shaking it up, and rub the affected places well with it, aud put your saddles and barfens on while the places are wet in order to prevent them from infecting other horses.

Sometimes horses have what are called Setfasts on their backs. Rub them with a little mercurial ointment, in order 
to raise them and make them come off; and if you can not pull them out after using the ointment, cut them out with a sharp knife, and apply to the place the above mixture, or heal it up as a common wound. Most excrescences on horses are cured in this manner.

\section{Windgalls.}

These are mostly on the hind legs, near the fetlock, but 1 have known them above the fetlock, and on the arm. Windgalls are not only eye-sores, but lame many a horse. Many methods are tried to disperse them without effect. If you put your finger on one side, and your thumb on the other, and press with one of them. you will find the Windgall to go quite through the leg. The reason that they are mostly on the hind leg is, because the loorse stands lower behind than before, and throws most weight on the hind legs.

Core.-On the first appearance of a Windgall, bathe the place well with warm rinegar and spirits of wine, and put a pretty tight bandage round it. If this do not remore it, lay on blistering ointment till the cure shall be completed. But. should this methorl also fail, which it seldom does, you must lay the $W$ indgall open and dress it as a common wound. Before you use the knife, be careful to get the horse's body into a proper cool state by physic.

\section{The Grease.}

This disorder is mostly brought on by soft corn, hard usage, want of proper cleaning, or a depraved state of the blood and juices; therefore it is proper to divide it into two heads.

Cure, when the Vessels are Relaxed.-On first observing the legs of a horse to swell atter standing several honrs, and to recover their proper dimensions with exercise, be careful to wash them clean with chamber-ley. soap-suds, or vinegar and water, every time he comes in. for this will prevent or remove the disorder. Horses that have round or fleshy legs are more subject to the Grease than those that have flit legs; but a flat-legged horse is more easily sprained. Nitre, sulphur, and liver of antimony, are proper both to prevent the Grease and to refine the blood. Mix equal parts of each, and give a meat-spoonful every day in his food.

CURE for the Grade from Isternal Cacsfs.-If the horse be full of flesh, the cure must be begun by bleeding, rowels, and repeated purging ; after which two ounces of the follow. 
ing balls should be given every other day for some time, and they will work by urine the day following :



Put these into a mortar with about two ounces of honey, or as much as will make them into balls, and they will carry off the offending humors, and fice the blood from its noxious qualities. But at the same time that these internal remedies are taken, outward ones should not be omitted. The leg's should be bathed with warm verjuice; and, if very bad, a poultice of boiled turnips applied. If turnips can not be got, make a poultice of linseed meal and bran, with a little hog's lard in to prevent it from growing hard.

Sometimes horses are neglected when in the Grease till they have what are called grape-legs. These may be cured on their first appearance, when they are in the bud, by lay. ing on caustic, or corrosive sublimate. When the swelling is abated, make the following into a salve to dress the sores with :

1 ounce of Blue Stone Vitriol, in powder.

2 ounces of White Lead, in powder.

4 ounces of Honey.

Mix these well together, and lay them on the sores with tow, to heal them; but, should they continue foul, and not frame to heal, mix four ounces of green salve, and four ounces of Agyptiacum ointment well together, and lay it on in the above manner. The mixture will both heal and dry up the sores.

\section{Scratches.}

This disease is a forermnner of the Grease, and is a hoi oozing matter that breaks out like links, with a nauseous smell. It is very troublesome to a horse, causing his heels to look red and angry, and to be rery sore; and sometimes it is so violent as to render a horse lame, and make him. unfit for use.

If you do not bleed and physic as soon as you find a heat in a horse's heels, you may soon have him laid in the Grease. Sometimes in sight touches of this complaint the heels are not hotter than usual. In that case, take a little flour of sulphur and spirits of wine, mix them together into an ointment, and fill the cracks well with it. When the disorder is 
too hot to be healed by this ointment, rub with a little Egyptiacum ointment, but be careful not to lay too much on, for it is a great drier.

Rat-tails at first resemble the Grease, and are attended with a hot scorbutic humor at the beginning, and often by neglect destroy the roots of the hair, and then there is no complete cure for them. but they may be relieved by rubbing with equal parts of strong mercurial ointment and Flanders oil of bass.

If a horse have got the Seurry, or Scabs on his legs, this ointment will mostly take them off ; but if not, mix well with hog:s lard, one dram of sulblimate, in fine powder. These two last mixtures will cure most Scabs, and mixed together they will cure the Itch.

\section{The Crown Scab.}

This disorder is similar to the last. It breaks out on the cornet of the foot, and is at first a hot running tumor. and afterwards a dry, scurry scab. Let the horse be bled and physicked, and then rub him with either of the abore ointinents, and the cure will be effected.

\section{How to. Manage a Horse on a Journey.}

In the first place, find out whether the horse is in health, and has been properly fed and exercised ; for when a horse is flushed up, and has had no exereise, he is very unfit for a journey. Before you set out be careful to obserre if his shoes are fast. and if they sit easy; also whether he cuts be. fore or behind, $c r$ interferes, as it is called. If a horse cnt with bad shoes. he will probably do it with new ones, notwithstanding what horse-dealers may say to the contrary.

If your horse's back inflame by the rubbing of the saddle, wash the part as soon as you perceire it with salt and water, or rinegar and water, and liave the stuffing of the saddle altered so as to remove the pressure from the part affected : but if the slin be broken before rou perceire it, the injured part should be washed with a mixture, composed of equal parts of extract of lead, spirits of wine, and water. You must look well after his back, and walk sometimes, in order to ease bim, especially when going down a hill.

It often bappens, especially to young horses, that the legs swell, or become gourdy, as farricrs call it, with-traveling, and more frequently when a horse cuts. It is also observed that the lind legs swell oftener than the fore legs, beenuse the fore parts stand lighest in the stall, and consequently 
the greatest stress lies on the hind legs. The best method of prevention is to wash the legs with warm water every time you bait, by which means the disease will be prevented, and much time, trouble and expense saved.

Nothing is of more consequence in traveling than to take care that your horse bas water at proper times and in proper quantities. When a horse travels he perspires considerably, especially in hot weather, and should therefore be allowed to drink a little more than usnal, as opportunity oflers. which will refresh him greatly; but never suller him to drink much at a time, for if you suffer him to drink his fill he will be dull and sluggish afterwards, besides the harm he may receive from drinking too much cold water when he is hot. Never allow your horse to be led to water, or to have his heels washed, after you have arrived at your inn, but let him have lukewarm water, or water moderately cool, when he has stood some time in the stable.

It is a general rule that when any extraneous body, or foreign matter, such as sand or gravel, is lodged in any part of the animal's body, it must be extracted as soon and as easily as possible. When gravelly matter has got into the quick at a nail-hole, or any other aperture, it ought to be removed as soon as possible, but with as little loss of substance as the nature of the case will admit of, for it is a folly to eut and pare away the hoof as some ignorant farrier's do ; because by that means they increase the evil instead of removing it, as it is a considerable time before the breach is repaired, and till that is done, the same part is likely to admit more gravel. So much, therefore, and no more, of the hoof should be taken away as is necessary, viz.: till the blackness or discoloration vanishes; then the wound should be dressed with the following balsam :

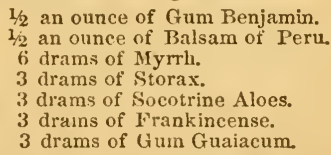

Powder the ingredients that will powder, and put them in a bottle with one quart of spirits of wine, and let them stand warm for eight or ten days, shaking the bottle up every day. This is an excellent balsam for green wounds, and no person that keeps valuable horses should be without it. $\Lambda$ pply it warm to the wound, dipping a piece of tow or lint into it, anc fastening it on to the part out of which the gravel or thorr has been taken, and renew it as it grows dry. 
Popular Books sent Froe of Postage at the Prices annexed.

The Sociable; or, One Thousan.l anil One IInme Amusements. Containing Acting Proverbs, Charades, Musical Burlesques, Tableaux Vivants, Parlor Games, Forfeits, Parlor Masic, und a choice rollection of curions mental and mechanical puzzles, etc. Illustrated with engruvings and diagrams.

$12 \mathrm{mo}$, cloth, gilt side stamp. Price.......................1 50

I ank Converse's Complete Banjo Instructor, without a Master. Containing $几$ choice collection of Banjo Solos. Hornpipes, Reels, 1 igs, IV alk-Aiouuds, Songs and Banjo Stories, progressively arranged ånd plainly explainesl, enabling the learner to become a proticient banjoist witlont the aid of a teacher. Illustrated with diagrams and explandtory symbols. 100 pages. Bound in boards, cloth back. Price............50 cts.

The Magician's Own Book. Containing several hunctrecl amusing Sleight-of-hand and Card Tricks, Perplexing Puzzles, Entertaming Tricks and Secret Writing Explained. Illustrated with over 500 woul engravings.

12mo., cloth, gilt side and back stamp. Price................\$1 50

The Secret Out; or, One Thoussnil Tricks voith Crids. A book which explains all the Tricks and Deceptions with Playing Carls ever known or invented. Illustrated with orer 360 engravings.

398 pages, $12 \mathrm{mo}$., cloth, gilt side. Price.......................\$1 50

Book of Riddles and 500 Home Amusements. Containing all kinil s of Curions Riddles, Amusing Puzzles, Queer Sleights and Entcr. taining Recreations in Science, for Family and Social Pastime. Illustrittewith G0 engravings. Paper covers. Price......................... 30 cts.

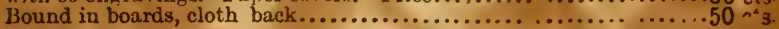

Parlor Tricks with Cards. Containing explanations of all the Deceptions with Playing Carls ever invented. The whole illustratel and male eașy with 70 engravings.

Paper covers. Price...................................... $3 n$ cts. Bound in boards, cloth back.................................5 50 cts.

The Book $\because$ Fireside Games. Conśaining a description of the most Entertaining Games suited to the Family Circle as a Recrestion. Paper covers. Price................................... 30 cts. Bound in boards, cloth back........................................

The Play-Room; or, In-Dinor Aames for Boys and Oirls. Small octavo, profusely illustrated with 197 fine wood-cuts.

Bound in boards, cloth back. Price........................... 50 cts. Bound in cloth, gilt side.....................................

The Play-Ground; or, Out-D.r $r$ Games for Boms. A book of healthy recreations for youth: Cuntaining over 100 Amusements. Illustrated with 124 tine woorl-cuts.

Bound in boards, cloth back. Price........................ 50 cts. Bound in cloth, gilt side....................................

The Parlor Magician; or, One ILumiterd Tricks for the Iruzoing-Ronm. Illustratcd and clcarly cxplained, with 121 engravings.

Paper covers. Price..........................................

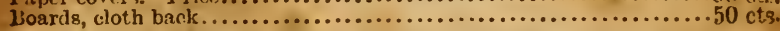

The Book of 500 Curious Puzzles. Containin m all kinds of entertaining Paredoxes, Deceptions in Numbers, etc. Tulustratrit with numerons arigrarlages. Panst covers. Price.................... 30 cts. Thound in binards; theth liark................................ 50 cts 
Dr. Valentinc's Comic Lectures; or, Morsels of Mirth for ths Melancholy. A budget of Wit and Irumor, and a certain eure for the blues and all other serious complaints. Comprising Comic Lectures on Heads, Faces, Noses, Mouths, Animal Magnetism, etc., with Specimens of Elon quence, Transactions of Learned Societies, Delineations of Eccentrie ( haracturs, Comic Songs, etc. By Dr. W. Valentine, the favorite Delincatus of Eccentric Characters. Illustrated with twelve portraits of Dr. Vaien tine, in his most celebrated characters.

12 mo., cloth, gilt. Price................................... 2 - Jrnamental paper cover. Price................................. 75 cts.

The Poet's Companion; A Dirtionary of all Allonable IRliymes in the English Language. This is a book to aid aspiring genius in the Compowition of Rhymes, and in Poetical Effusions generally. It gives the P'erfect, the Impertect, and the Allowable Rhymes, and will enable you to ascertain, to a ceriainty, whether any words can be mated. It is invaluable to any one $m$ ho desires to court the muses, and is used by some of llie lest



Ladies' Guide to Crochet. By Mrs. Ann S. Stephens. Copiously illustrated with original and very choice designs in Crochet, etc. printed in colors, separate from the letter-press, on tinted papcr. Also with numerous wood-cuts, printed with the letter-press, explunatory of terms, etc. Bound in extra eloth, gilt. This is by tar the best work on the subject of Crochet ever publishicd.

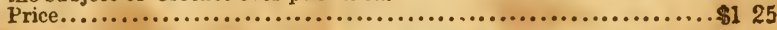

Chips from Uncle Sam's Jack Knife. Illustrated with over one hundred Comical Engravings, and comprising a collection ut oves five hundred Langhable Stores, Funny Adventures, Comic Poetry. Quecr Conundrums, 'Territic l'uns, Witty Sayings, Sublime Jokes, and Sentim:ental Sentences. 'The whole being a most periect portfolio for those who love to laugh. Large vetavo. Price............................... cts.

Fox's Ethiopian Comicalities. Containi. Strange Sayings, Eccentric Doings, Burlesque Speeche: Laughable Trolleries, I unny Stories, interspersed with Refined Wit, Broad Humor, and Cutting Sarcasm, copied verbatim, as recited by the celebrated Ethiopian Comedian.

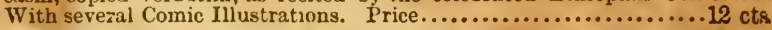

Mind Your Stops. Punctuation made plain, and Composition simplitied for Realers, Writers and Talkers. This little book is wortih ten times the price asked for it, and will teach accurately in every: thing, from the diction of a firendly letter to the composition of a lenrned

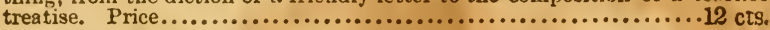

Hard Words Made Easy. Rules for Pronunciation and Accent; with instructions how to pronounce French, Italian, German, Danish, Dutch, Swedish, Norwegian, and other foreign names. A capital

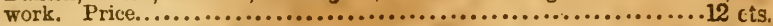

B.idal Etiquette; A Sensible Guide to the Etiquette ar a Observances of the Marriage Ceremonips; containing complete directicis for Bridal Receptions, and the necessary rules for bridesmaids, groom $\leqslant m \in \cdot 11$,

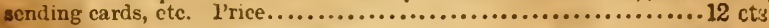

The Universal Book of Songs. Comprising a choice collection of $400 \mathrm{new}$ Sentimental, Scotch, Irish, Ethiopian and Comic Songs.

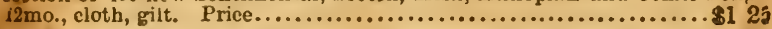

How to be Healthy; Being a Complete Guide to Iong Lito. By a Retired Phyeician. Prime....6...5...............12 cta 


\section{GOOD BOOKS}

Eent Frene of Poedage at the Prioes Marired

$$
-\frac{y}{2}
$$

Le 'if ẩchand's Fortune Téier and Dream Book, Thi Young Reporterf or, How to Write Short Hand, Brisbane's folden Rzady-Rcokoner, ....?...

The Ameridan Hoy'es or, Geatleman's Book of Games, ....... -2 r's The Look of Zidales, and 500 Amusements, ................... The Peslor Niggieian, 200 nlustrations, ........................ 50 Parlor Trisks with Cards, .................................. . . 50 Hillgrow's Baj fiom Guile, ................................ .

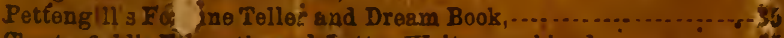
Chesterfield's Etiquette and Latter Writer combined, -.............. 35 Tontaine's Goldar Wheol Dream Book and Fortune Teller, . ...... Everlasting For funo Teller and Mol zetic Dream Book, .............

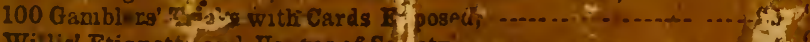

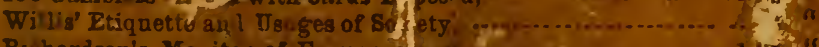
Riuhardson's Monitor of Fruemaso

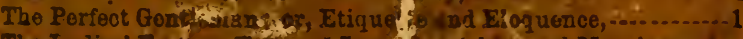
The Ladies' Fortune ferter or Love 'f gurtsh.jpand Man'iage, -... How to Play. Whist, Euchre, Lro, \& \& Poker, Horse Trming, as pragticed by J. है R rey, ........ . t .........



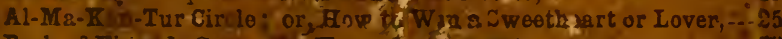

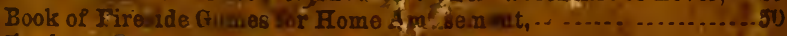
Book of sol Curinu 8 Puzzles, with ibo nlustrations, .............50 The Servetput; $c$, 1,0no Tricks filic Cards, ................. 50

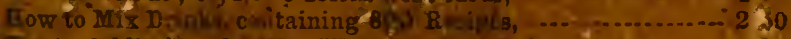

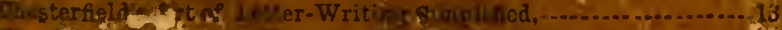

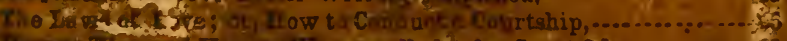



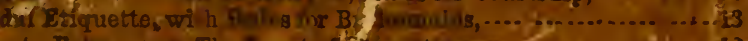

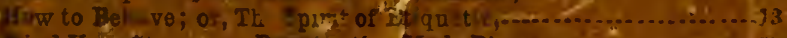

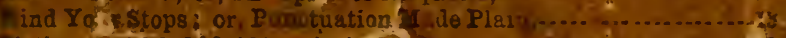
Dietionary of 3,000 a bbreviatiug $\mathrm{f}$.

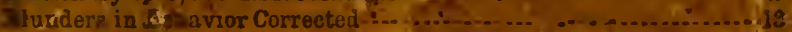



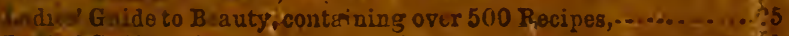
Living Guif to to Crochet. Cloth, Gilt, .......................... if The Amerzo in Home Cook Book, ................................... Live and Learn; or, 1,000 Mistakes in spewkite and Writing

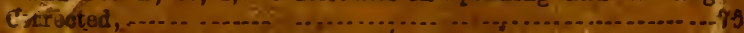


Doxing Madis Easy; and Hrw to Wrentle, -c.................... 17 Copriship Mode Easy; on th Art of Making Lovesully Explainod is Ladier Gnide to Bearty. By Lola Montepi....................... है Thu Game of Chock r Simplified axid Exp lined, , ............ है 